UNIVERSIDADE DE SÃO PAULO

ESCOLA DE ENGENHARIA DE SÃO CARLOS

OLIVIA CARR

Desenvolvimento de genossensor para a detecção precoce de câncer de cabeça e pescoço

São Carlos

2019 



\section{OLIVIA CARR}

Desenvolvimento de genossensor para a detecção precoce de câncer de cabeça e pescoço

Versão Corrigida

Tese apresentada ao programa de Pós-Graduação em Ciência e Engenharia de Materiais da Universidade de São Paulo, para obtenção do título de Doutor em Ciências.

Área de concentração: Desenvolvimento, Caracterização e Aplicação de Materiais.

Orientador: Prof. Dr. Osvaldo Novais de Oliveira Junior 
AUTORIZO A REPRODUÇÃO TOTAL OU PARCIAL RESTE TRABALHO. POR QUALQUER MEIO CONVENCIONAL OU ELETRONNICO, PARA FINS DE ESTUDO E PESQUISA, DESDE QUE CITADA A FONTE.

Ficha catalográfica elaborada pela Biblioteca Prof. Dr. Sérgio Rodrigues Fontes da EESC/USP com os dados insendos pelo(a) autor(a).

C311d Carr, Olivia precoce de cfincer e peacoço / Olivia Carr; orientador

Teae (Doutorado) - Programa de P6e-Graduação em Ciencia e Engenharia de Materiaia e Área de Concentraçăo em Demenvolvimento, Caracterizaço e Aplicação de Materiaia -- Eacola de Engenharia de São Carlou da Univeraidade de Săo Paulo, 2019.

1. Genonmeneor; 2. Cincer cabeça e pencoço; 3. Scido mercaptoundecan6ico; - 4. Scido mercaptouctico. I. Titulo. 


\section{FOLHA DE JULGAMENTO}

Candidata: Bocharela OUVIA CARR.

Titulo da tese: "Desenvolvimento de genossensor para detecçoo precoco de côncer de cobeça e pescoço".

Dala da defesa: $13 / 11 / 2019$.

Comissōo Julqudora:

Profa. Titular Osvaldo Novais de Oliveira Junior

(Orlentadora)

(Instituto de Fisica de Soo Carlos/PSC-USP)

Prof. Dr. Antonlo Rlul Júnior

(Universidade Estadual de CampinasfUNICAMP)

Prol, Dr. Bruno Campos Janegitz

[Universidade Federdi de Săo Carlos/UFSCar)

Dr. Daniel Souza Corrểa

(Empresa Brasileira de Pesquiso Agropecubria/EMBRAPA)

Dro. Ano Rita de Araujo Nogueira

[Empresa Brasileira de Pesquisa Agropecuárid/EMaRAPA]
Resultado:

\section{theipist}

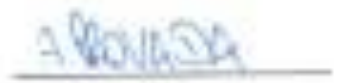

APRONADA

Coordenador do Programg de Pós-Graduaçăo em Ciência en Engenharia de Materiais:

Prof. Associocio Marcelo Falcao de Oliveira

Presidente da Comissōo de Pós-Graduação:

Prof. Titular Murilo Araujo Romero 

Aos meus pais, Edson e

Siomara, pela compreensão,

carinho e apoio incansável. 

A Deus, por ser minha esperança e fé durante estes quatro anos.

Aos meus pais Edson e Siomara, que sempre estiveram ao meu lado, me dando apoio, principalmente me encorajando a continuar a caminhada. Sempre me deram muito amor e carinho em todos os momentos.

A minha irmã Joyce, que sempre foi minha companheira e amiga.

Ao professor Osvaldo Novais de Oliveira Jr (Chu) pelos ensinamentos, discussões, paciência, pelo incentivo, autonomia, confiança e amizade.

As amigas Lorena Alencar e Lílian Menezes pela amizade, companheirismo nos momentos mais difíceis. É uma amizade que guardo com muito carinho.

Aos amigos do IFSC pelas discussões que contribuíram para minha formação, pelos momentos de descontração e risadas e principalmente pela amizade: Caface, Cris, Makoto, Nirav, Gisela, Adriano.

Ao corpo técnico do Grupo de Polímeros do IFSC: Debora Balogh, Níbio, Manoel, Marcos Felipe, Bruno, Ademir, Marcelo, Bertho, Rô e Simone.

À Maria Helena Piazzetta (Nena), Rui Murer e Angelo Luiz Gobbi, do Laboratório de Microfabricação do CNPEM, pelo auxilio na confecção dos eletrodos interdigitados e principalmente pela amizade.

Aos pesquisadores do Hospital do Câncer de Barretos: Dr. André Lopes Carvalho, Dr. José Humberto Fregnani, Dr. Matias Melendez e Dra. Lidia Rebolho pelo apoio e auxilio na parte clínica.

Ao Hospital do Câncer de Barretos pelo fomento e pelas amostras de células cedidas.

À secretaria do PGrCEM: Victor Barioto e todos os estagiários.

À CAPES pelo fomento. 

CARR, O. Desenvolvimento de genossensor para a deteç̧ão precoce de câncer de cabeça e pescoço. 2019. 119p. Tese (Doutorado) - Escola de Engenharia de São Carlos, Universidade de São Paulo, São Carlos, 2016.

A detecção precoce do câncer aumenta as chances de cura, mas infelizmente o diagnóstico em geral se dá após a doença ter se espalhado e atingido diferentes órgãos e tecidos. Este trabalho visa a desenvolver genossensores para detectar câncer de cabeça e pescoço em estágio inicial. Obteve-se um genossensor preciso, rápido e de baixo custo com unidades sensoriais consistindo em sondas de DNA de fita simples. Estas sondas são imobilizadas em eletrodos de ouro modificado por monocamada automontada (SAM) de ácido mercaptoundecanóico (MUA). A otimização das condições de fabricação dos sensores e a caracterização foram feitas com diferentes técnicas, incluindo espectroscopia de absorção e reflexão no infravermelho com polarização modulada (PM-IRRAS), espectroscopia de geração de soma de frequência (SFG) e medidas de ângulo de contato. A deteç̧ão foi feita com espectroscopia de impedância eletroquímica, com clara distinção entre amostras de DNA com sequência complementar à sonda, indicativo de câncer. Além disso, amostras de células com DNA não complementar puderam ser distinguidas das células com alto grau de metilação na linhagem HN13 (97\% de metilação), verificando-se a seletividade. $O$ genossensor é sensível com baixo limite de detecção $(0,24 \mathrm{pM})$ em uma faixa de concentração linear entre $1,0 \times 10^{-11}$ e 5,0 $\times 10^{-8} \mathrm{M}$ e entre $1,0 \times 10^{-8}$ e $1,0 \times 10^{-6} \mathrm{M}(277 \mathrm{pM})$. As amostras com diferentes concentrações da sequência complementar e diferentes células puderam ser separadas em projeções multidimensionais com a técnica interativa para visualização de documentos (IDMAP). A matriz e os procedimentos de imobilização podem ser estendidos para imobilizar sondas de DNA na fabricação de genossensores para outros tipos de câncer. Verificou-se, após uma série dessas tentativas, que a maior dificuldade em obter um genossensor é garantir que a matriz para imobilização da sequência de DNA (probe) seja adequada, principalmente no que concerne à organização do filme nanoestruturado que serve para acomodar os DNAs.

Palavras Chaves: Genossensor; Câncer cabeça e pescoço; ácido mercaptoundecanóico; ácido mercaptoacético. 

CARR, O. Genosensors for early detection of head and neck cancer. 2019. 119p. Tese (Doutorado) - Escola de Engenharia de São Carlos, Universidade de São Paulo, São Carlos, 2016.

Early detection of cancer increases the chances of cure, but unfortunately the diagnosis is usually made after the disease has spread and reached different organs and tissues. This work aims to develop genosensors to detect head and neck cancer at early stages. An accurate, fast and low cost genosensor was obtained with sensing units consisting of single stranded DNA probes. These probes are immobilized on gold electrodes modified with mercaptoundecanoic acid (MUA) self-assembled monolayers (SAM). Sensor manufacturing conditions were optimized and characterized using different techniques, including polarization-modulated infrared absorption and reflection spectroscopy (PMIRRAS), sum frequency generation spectroscopy (SFG), and contact angle measurements. Detection was performed with electrochemical impedance spectroscopy, with clear distinction between DNA samples with complementary sequences to the probe, indicative of cancer. In addition, samples from cells with non-complementary DNA could be distinguished from cells with a high degree of methylation in the HN13 strain (97\% methylation), thus confirming selectivity. The genosensor is sensitive with low detection limit $(0.24 \mathrm{pM})$ in a linear concentration range between $1.0 \times 10^{-11}$ and $5.0 \times 10^{-8} \mathrm{M}$ and between $1.0 \times 10^{-8}$ and $1.0 \times 10^{-6} \mathrm{M}(277 \mathrm{pM})$. Samples with different concentrations of the complementary sequence and different cells could be separated into multidimensional projections using the visualization technique IDMAP (interactive document mapping). The matrix and immobilization procedures can be extended to immobilize DNA probes in fabricating genosensors for other types of cancer. It has been found, after a series of such attempts, that the greatest difficulty in obtaining a genosensor is to ensure that the immobilization of the DNA probe is adequate, especially with regard to the organization of the nanostructured film that serves to accommodate the DNA probes.

Keywords: Genosensor; Head and neck cancer; mercaptoundecanoic acid; mercaptoacetic acid. 



\section{LISTA DE FIGURAS}

Figura 1: Representação esquemática de um biossensor. Diferentes elementos de biorreconhecimento e transdutores estão representados. 33

Figura 2: Estrutura dos nucleotídeos. 36

Figura 3: (a) Célula eletroanalítica de três eletrodos: (1) Contra-eletrodo, (2) Referência e (3) Trabalho; (b) Circuito equivalente para descrever comportamento eletrodo/solução; (c) Diagrama de Nyquist referente ao circuito equivalente; (d) Diagrama de Bode. 41

Figura 4: Eletrodo de ouro com área delimitada 47

Figura 5: Esquema da construção do genossensor. 48

Figura 6: Definição do ângulo de contato $\theta$ entre uma gota de um líquido e a superfície. 50

Figura 7: Espectro PM-IRRAS para monocamada automontada (SAM) de ácido mercaptoacético (MAA) imobilizada em diferentes tempos. 56

Figura 8: Deslocamento da banda $v_{a s}\left(\mathrm{CH}_{2}\right)$ em função do tempo de imobilização no espectro PM-IRRAS da monocamada automontada (SAM) de ácido mercaptoacético (MAA). 57

Figura 9: Espectro PM-IRRAS da monocamada automontada (SAM) de ácido mercaptoacético (MAA) e ácido 11-mercaptoundecanóico (MUA) imobilizada em 1 dia e 30 dias. 58

Figura 10: Espectro de PM-IRRAS: (a) Sonda (NH2-ssDNA) imobilizada sobre MUA em ouro; (b) sequência complementar (ds-DNA) hibridizada na sonda; (c) sequência não complementar (nc-DNA). 59

Figura 11: Ângulos de contato do eletrodo de ouro, monocamadas automontadas (MAA) preparadas em água e etanol, sonda $\left(\mathrm{NH}_{2}^{-}\right.$ ssDNA), sequência complementar (ds-DNA) e não complementar (nc$D N A)$. São apresentadas medidas para três líquidos: água, formamida e diiotometano. 64

Figura 12: Ângulos de contato do eletrodo de ouro, monocamadas automontadas (MUA) preparadas em etanol, sonda ( $\left.\mathrm{NH}_{2}-\mathrm{ss} D N A\right)$, etanolamina (Et-OH), sequência complementar (ds-DNA) e não complementar (nc-DNA). Medidas para os líquidos: água, formamida e 
diiodometano. 66

Figura 13: Gráficos de energia de superfície do eletrodo de ouro, monocamadas automontadas (SAM) de MAA preparadas em água e etanol, sonda ( $\mathrm{NH}_{2}$-ssDNA), sequência complementar (ds-DNA) e não complementar (nc-DNA). 68

Figura 14: Gráficos de energia de superfície do eletrodo de ouro, monocamadas automontadas (SAM) de MUA preparada em etanol, sonda $\left(\mathrm{NH}_{2}-\right.$ ssDNA), etanolamina ( $E t-O H)$, sequência complementar (ds-DNA) e não complementar (nc-DNA). 69

Figura 15: a) Resistência à transferência de carga $\left(R_{c t}\right)$ da sonda $\left(\mathrm{NH}_{2}-\mathrm{ssDNA}\right)$ e da sequência complementar (ds-DNA) para SAM preparada em água e etanol obtida das medidas eletroquímicas; b) espectro de PM-IRRAS apenas do eletrodo modificado com SAM em água e etanol 71

Figura 16: Espectro de impedância do genossensor construído a partir da monocamada automontada de MAA em etanol, sonda $\left(\mathrm{NH}_{2}\right.$-SsDNA) e sequência complementar (ds-DNA) $\left(10^{-8} \mathrm{M}\right)$ com diferentes temperaturas de hibridização: $25,35,45,60$ e $80^{\circ} \mathrm{C}$. 73

Figura 17: Diferença do sinal $\left(|Z|-\left|Z_{0}\right|\right)(1 \mathrm{~Hz})$ em função da temperatura de hibridização para a sequência complementar (ds-DNA) $\left(10^{-8} \mathrm{M}\right)$. 74

Figura 18: Espectros de impedância do genossensor construído com a monocamada automontada de MAA em etanol, sonda $\left(\mathrm{NH}_{2}\right.$-SsDNA) e sequência complementar (ds-DNA), para várias concentrações $\left(10^{-9}\right.$ a $10^{-6} \mathrm{M}$ ). Temperatura de hibridização fixa em $80^{\circ} \mathrm{C}$. 75

Figura 19: Espectros de impedância do genossensor construído a partir da monocamada automontada de MAA em etanol, sonda $\left(\mathrm{NH}_{2}\right.$-SsDNA) e sequência não complementar (nc-DNA) variando a concentração $\left(10^{-9} \mathrm{a}\right.$ $\left.10^{-6} \mathrm{M}\right)$. A temperatura em que os experimentos de detecção foram realizados era de $80^{\circ} \mathrm{C}$. 76

Figura 20: Diferença do sinal $\left(|Z|-\left|Z_{0}\right|\right)$ em $1 \mathrm{~Hz}$ em função do logaritmo da concentração da sequência complementar (ds-DNA) e não complementar (nc-DNA). Temperatura em que as medidas foram realizadas: $80^{\circ} \mathrm{C}$. 77

Figura 21: Espectros de impedância do genossensor contendo monocamada 
automontada de MAA em etanol, sonda ( $\mathrm{NH}_{2}$-ssDNA) e sequência complementar (ds-DNA) variando a tempo de exposição (5 a $60 \mathrm{~min}$ ) com a temperatura de $80^{\circ} \mathrm{C}$. 78

Figura 22: Diferença do sinal $\left(|Z|-\left|Z_{0}\right|\right)(1 \mathrm{~Hz})$ em função tempo de exposição a $80^{\circ} \mathrm{C}$, da sequência complementar (ds-DNA) com concentração de $10^{-8}$ M. 79

Figura 23: Espectros de impedância do genossensor construído a partir da monocamada automontada de MAA em etanol, sonda $\left(\mathrm{NH}_{2}\right.$-SSDNA) e etanolamina, com diferentes temperaturas de hibridização: 25, 35, 40, 60 ${ }^{\circ} \mathrm{C}$. Em (a) sequência complementar (ds-DNA) $\left(10^{-8} \mathrm{M}\right)$ e (b) sequência não complementar (nc-DNA) $\left(10^{-8} \mathrm{M}\right)$. 80

Figura 24: Diferença do sinal $\left(|Z|-\left|Z_{0}\right|\right)(1 \mathrm{~Hz})$ em função Temperatura de hibridização, da sequência complementar (ds-DNA) e não complementar (nc-DNA) com concentração de $10^{-8} \mathrm{M}$, respectivamente. 81

Figura 25: Espectros de impedância do genossensor com monocamada automontada de MAA em etanol, sonda ( $\mathrm{NH}_{2}$-SSDNA) e etanolamina. (a) sequência complementar (ds-DNA) e (b) não complementar (nc-DNA). Temperatura de hibridização fixa em $60^{\circ} \mathrm{C}$. 82

Figura 26: Diferença do sinal $\left(|Z|-\left|Z_{0}\right|\right)(1 \mathrm{~Hz})$ em função da concentração: sequência complementar (ds-DNA) e não complementar (nc-DNA). 84

Figura 27: Espectros de impedância, etapa por etapa, da construção do genossensor, a partir da monocamada automontada MAA, e medidas com a sequência complementar (ds-DNA) em diferentes concentrações. Temperatura de hibridização igual a $\mathrm{Tm}-5{ }^{\circ} \mathrm{C}$. 85

Figura 28: Diferença do sinal $\left(|Z|-\left|Z_{0}\right|\right)$ (1 Hz) em função da concentração da sequência complementar (ds-DNA) com temperatura de hibridização igual a $\mathrm{Tm}-5^{\circ} \mathrm{C}$. 86

Figura 29: Espectros de impedância, etapa por etapa, da construção do genossensor, a partir da monocamada automontada MAA para a sequência complementar (ds-DNA) em diferentes concentrações com a temperatura de hibridização igual a $\mathrm{Tm}+5{ }^{\circ} \mathrm{C}$. 87

Figura 30: Diferença do sinal $\left(|Z|-\left|Z_{0}\right|\right)(1 \mathrm{~Hz})$ em função da concentração da sequência complementar (ds-DNA) e não complementar (nc-DNA) com 
temperatura de hibridização igual a $\mathrm{Tm}+5^{\circ} \mathrm{C}$. 88

Figura 31: Espectros de impedância, etapa por etapa, da construção do genossensor, a partir da monocamada automontada MAA para a sequência complementar (ds-DNA) em diferentes concentrações com a temperatura de hibridização de $\mathrm{Tm}+10^{\circ} \mathrm{C}$. 89

Figura 32: Diferença do sinal $\left(|Z|-\left|Z_{0}\right|\right)(1 \mathrm{~Hz})$ em função da concentração da sequência complementar (ds-DNA) e não complementar (nc-DNA) com temperatura de hibridização igual a $\mathrm{Tm}+10^{\circ} \mathrm{C}$. 90

Figura 33: Espectros de impedância, etapa por etapa, da construção do genossensor, a partir da monocamada automontada MAA para a sequência complementar (ds-DNA) em diferentes concentrações com temperatura de hibridização igual a $\mathrm{Tm}+10{ }^{\circ} \mathrm{C}$

Figura 34: Diferença do sinal $\left(|Z|-\left|Z_{0}\right|\right)(1 \mathrm{~Hz})$ em função da concentração da sequência complementar (ds-DNA) com temperatura de hibridização igual a $\operatorname{Tm}+10^{\circ} \mathrm{C}$. 92

Figura 35: Espectros de SFG monocamada automontada (SAM) de ácido mercaptoacético (MAA) imobilizada em diferentes tempos 94

Figura 36: Espectros de impedância, etapa por etapa, da construção do genossensor, a partir da monocamada automontada MUA em etanol. 96

Figura 37: Espectros de impedância dos genossensores construídos a partir da monocamada automontada de MUA em etanol, com diferentes concentrações da sequência complementar (ds-DNA) (a) e da sequência não complementar (nc-DNA). 97

Figura 38: Curva analítica obtida dos espectros de impedância eletroquímica na frequência de $1 \mathrm{~Hz}$, com diferentes concentrações da sequência complementar (ds-DNA) e não complementar (nc-DNA), a partir da SAM com MUA. 99

Figura 39: Espectros de impedância dos genossensores construídos a partir da monocamada automontada de MUA em etanol, da sequência complementar (ds-DNA), sequência com 1 base trocada (1b-DNA) e da sequência não complementar (nc-DNA), com $1 \mu \mathrm{M}$. 100

Figura 40: Gráfico da diferença de sinal $\left(|Z|-\left|Z_{0}\right|\right)$ correspondente à hibridização com $1 \mu M$ das diferentes sequências de DNA (ds-DNA, 1b-DNA, nc- 
DNA).

Figura 41: Espectro de impedância correspondente à hibridização com $0,2 \mathrm{ng} / \mu \mathrm{L}$ de DNA com diferentes graus de metilação das linhagens de células SCC25, FaDu, JHU28, HN13. 102

Figura 42: Gráfico da diferença de sinal $\left(|Z|-\left|Z_{0}\right|\right)$ correspondente à hibridização com 0,2 $\mathrm{ng} / \mu \mathrm{L}$ de DNA com diferentes graus de metilação das linhagens de células SCC25, FaDu, JHU28, HN13. 103

Figura 43: Mapas de IDMAP obtidos das curvas de impedância x frequência (a) de amostras comerciais (ds-DNA e nc-DNA)em PBS, (b) amostras de linhagens celulares graus de metilação das linhagens de células SCC25, FaDu, JHU28, HN13. 104 



\section{LISTA DE TABELAS}

Tabela 1: Comprimento da sequência de DNA e comparação com comprimentos de Mercaptos. 46

Tabela 2: Atribuição das bandas com deconvolução dos espectros de PMIRRAS da Figura 10. 61

Tabela 3: Parâmetros de área e largura de banda das bandas com deconvolução dos espectros de PM-IRRAS da Figura 10. 62 



\section{LISTA DE SIGLAS}
A
Adenina
C
Citosina
CECP
Carcinoma espinocelular de cabeça e pescoço
DNA
Ácido Desoxirribonucleico
ds-DNA
DNA de Cadeia dupla (double-stranded DNA)
EDC
1-etil-3-(3-dimetilaminopropil)carbodiimida
G
Guanina
MAA
Ácido mercaptoacético
MUA
Ácido 11-mercaptoundecanóico
$\mathrm{NH}_{2}$-SsDNA
Sonda de DNA Cadeia simples (single-stranded DNA)
NHS
$\mathrm{N}$-hidroxissuccinimida
nc-DNA
Sequência não complementar de DNA
PBS
Tampão fosfato salino (Phosphate buffered saline)
PM-IRRAS
Espectroscopia de Reflexão-Absorção na Região do Infravermelho com Modulação da Polarização
SAM
Self-Assembled Monolayer (Monocamada Automontada)
SFG
Espectroscopia de geração de soma de frequência
$\mathrm{T}$
Timina
$|\mathrm{Z}|$
Módulo da impedância 



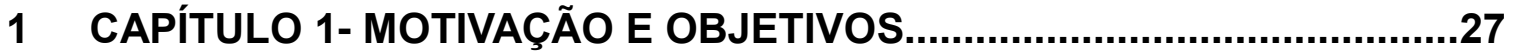

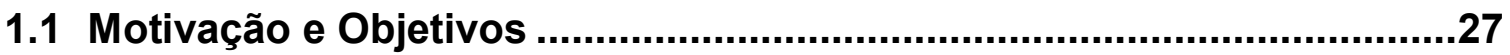

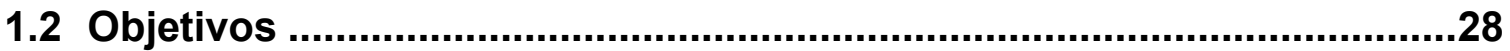

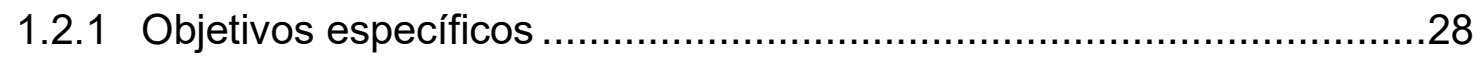

2 CAPÍTULO 2- INTRODUÇÃO E REVISÃO BIBLIOGRÁFICA .....................31

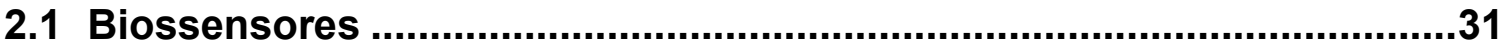

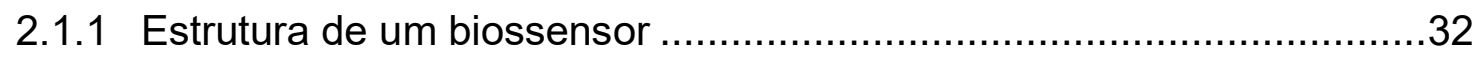

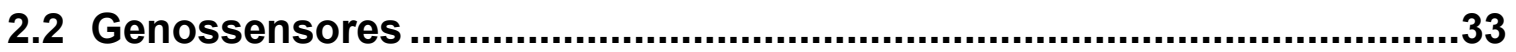

2.2.1 Elementos de biorreconhecimento dos genossensores ......................34

2.2.2 Principais métodos de imobilização em genossensores ……...............37

2.2.3 Princípios dos métodos de detecção eletroquímica em genossensores

2.3 Espectroscopia de Impedância Eletroquímica .40

3 CAPÍTULO 3- MATERIAIS E PROCEDIMENTOS EXPERIMENTAIS ........45

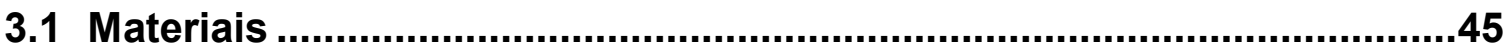

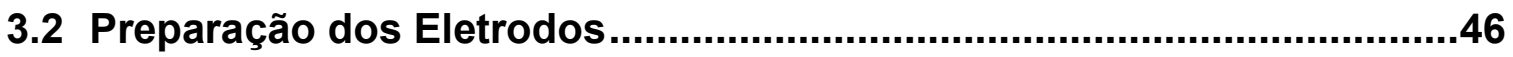

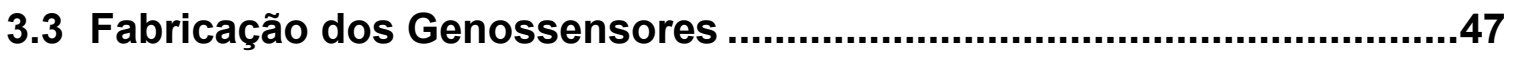

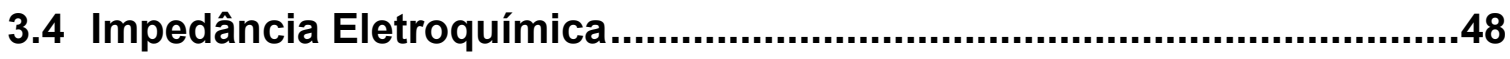

3.5 Espectroscopia de Reflexão-Absorção na Região do Infravermelho com modulação da polarização (PM-IRRAS)

3.6 Ângulo de Contato e Energia de Superfície .50 
4.1 Caracterização da Monocamada Automontada (SAM) e do genossensor 55

4.1.1 PM-IRRAS 55

4.1.2 Medidas de Ângulo de Contato e Energia de superfície.................... 63

4.2 Otimização do Genossensor com MAA............................................. 69

4.2.1 Influência do solvente na SAM (MAA) ..................................... 69

4.2.2 Tentativas Frustradas de Obter Seletividade com Genossensores...... 72

4.2 .3 Medidas de SFG .................................................................. 93

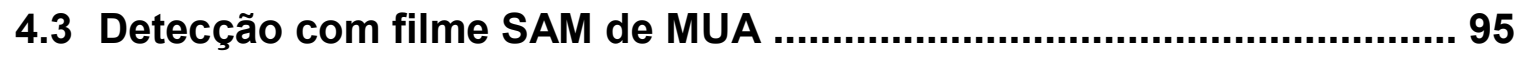

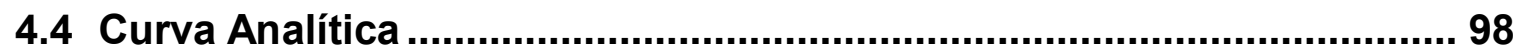

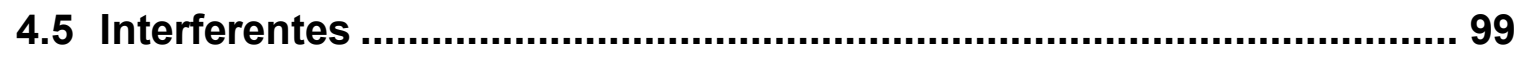

4.6 Detecção em Amostras Reais .........................................................101

4.6.1 Visualização dos Dados .........................................................103

4.6.2 Comparação genossensores com a literatura ...............................105

5 CAPÍTULO 5- CONCLUSÕES E PERSPECTIVAS FUTURAS .................107

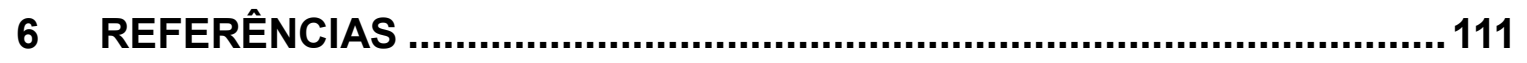


Esta tese está dividida em 5 capítulos: no CAPÍTULO 1 estão descritos a motivação e os objetivos do trabalho, discorrendo-se sobre a importância de detecção precoce de câncer e a utilização de biossensores para esse fim. $O$ CAPÍTULO 2 traz uma introdução aos principais tópicos do trabalho, incluindo revisão bibliográfica. $O$ foco do capítulo está em biossensores, especificando-se a importância de genossensores, pois este é o tipo de biossensor empregado nesta tese. Apresentam-se também os fundamentos das técnicas de detecção. O CAPÍTULO 3 apresenta os materiais e procedimentos experimentais empregados; o CAPÍTULO 4 contém os resultados e suas discussões, divididos em caracterização dos filmes nanoestruturados, e otimização para obter genossensores eficazes. Antes de mostrar os resultados bem-sucedidos com detecção dos biomarcadores em amostras de tampão e em células fornecidas pelo Hospital de Câncer de Barretos, são discutidas as tentativas frustradas de obter genossensores seletivos. Verificou-se, após uma série dessas tentativas, que a maior dificuldade em obter um genossensor é garantir que a matriz para imobilização da sequência de DNA (probe) seja adequada, principalmente no que concerne à organização do filme nanoestruturado que serve para acomodar os DNAs. Embora sejam resultados negativos, a constatação da importância da matriz é uma contribuição deste trabalho de tese. O CAPÍTULO 5 encerra a tese com conclusões e perspectivas para trabalhos futuros. 



\section{CAPÍTULO 1- MOTIVAÇÃO E OBJETIVOS}

\subsection{Motivação e Objetivos}

A principal motivação para o trabalho desta tese é o desenvolvimento de biossensores para o diagnóstico precoce de câncer. Escolheu-se um tipo de câncer de cabeça e pescoço, para o qual um diagnóstico nos estágios iniciais da doença é essencial. Trata-se do carcinoma espinocelular de cabeça e pescoço (CECP), um tipo agressivo de tumor maligno nas membranas mucosas epiteliais do trato aerodigestivo superior (orofaringe, hipofaringe e laringe) e cavidade oral, com uma incidência anual de 685.000 pacientes no mundo (L.; T.; M., 2010). Por ser a neoplasia maligna mais comum da cavidade bucal, o carcinoma espinocelular de cavidade oral (CCEO) é um problema de saúde pública com incidência anual superior a 300.000 casos, e com pacientes tendo problemas na fala, mastigação, paladar, deglutição e estética (WANG et al., 2014). Esse tipo de câncer leva a baixa taxa de sobrevivência, atribuída a recorrências de células tumorais que voltam a se multiplicar (loco-regional) e ocorrência de novos tumores, além de óbitos por comorbidade (existência de duas ou mais doenças). Uma das razões para essa baixa taxa de sobrevivência é que o diagnóstico é feito em estágio avançado do CCEO para a maioria dos pacientes (MONTEBUGNOLI et al., 2014). Apenas cerca de um terço dos pacientes apresenta doença em estágio inicial. $O$ indicador prognóstico mais importante para recaída do CCEO é a disseminação metastática para os gânglios linfáticos no pescoço (GROBE et al., 2014).

Uma maneira de diagnosticar a doença em estágio inicial é detectar biomarcadores, principalmente os marcadores moleculares para detecção de tumores, como algumas proteínas, DNA e RNA. Para câncer de cabeça e pescoço, Righini et al. (RIGHINI et al., 2007) avaliaram amostras de tumor e identificaram um conjunto de seis genes com frequências de hipermetilação de $82 \%$. Na análise de amostras de pacientes com CECP, cinco genes (CCNA1, DAPK, DCC, MGMT e TIMP3) apresentaram alta especificidade e sensibilidade (ARANTES et al., 2014). Assim, a metilação do DNA serve como biomarcador útil para uso clínico.

Exames para o diagnóstico de câncer são realizados com procedimentos invasivos e exames imunológicos (SOPER et al., 2006) demorados e de alto custo, 
dificultando o acesso da população em geral. Este cenário requer o desenvolvimento de novos métodos de detecção, de baixo custo e rápida resposta, para orientar o corpo médico acerca do tratamento a ser aplicado. Dentre estes métodos estão os genossensores para detecção de metilação do DNA, que ocorre antes de a doença evoluir. Isso possibilita aplicar o tratamento adequado no estágio pré-inicial da doença, principalmente nos casos em que o câncer é agressivo.

\subsection{Objetivos}

O objetivo principal deste trabalho é fabricar biossensores para detectar marcadores biológicos de câncer de cabeça e pescoço. O estudo da produção, caracterização e otimização dos filmes nanoestruturados que compõem os biossensores constitui $\mathrm{o}$ alicerce do trabalho. Além do elemento transdutor, $\mathrm{o}$ biossensor depende do método de detecção e da forma de explorar os dados adquiridos.

\subsubsection{Objetivos específicos}

i) Fabricação de filmes nanoestruturados com arquitetura molecular controlada como matriz para os genossensores, usando-se monocamadas automontadas (SAM).

ii) Fabricação da camada bioativa através da imobilização de sondas de DNA ( $\mathrm{NH}_{2}$-ssDNA) com uma única fita específica (complementar) para regiões promotoras de genes de interesse sobre os filmes nanoestruturados fabricados em (i). Essas sondas são responsáveis pela especificidade do biossensor, formando a parte fundamental da plataforma sensorial.

iii) Caracterização dos filmes nanoestruturados e das unidades sensoriais por técnicas de espectroscopia eletrônica e vibracional (PM-IRRAS), espectroscopia de geração de soma de frequências (SFG), medidas de ângulo de contato e espectroscopia de impedância eletroquímica. 
iv) Medidas eletroquímicas para detecção em soluções padrão dos DNA provenientes de linhagens celulares de tumores de cabeça e pescoço, utilizando a técnica de espectroscopia de impedância eletroquímica. 


\section{CAPÍTULO 2- INTRODUÇÃO E REVISÃO BIBLIOGRÁFICA}

A literatura sobre biossensores é vasta, pois esse tipo de dispositivo vem sendo empregado de maneira crescente. A título de ilustração, uma busca na Web of Science em agosto de 2019 aponta para quase 86.000 artigos obtidos com o termo "biosensor". Há muitos artigos de revisão sobre biossensores (FABRI-FAJA et al., 2019; KALKREUTER et al., 2019; SU; LI; KERMAN, 2019) de maneira que não serão apresentadas informações detalhadas aqui. São discutidos apenas alguns aspectos introdutórios, com ênfase nos genossensores, que é o tipo de biossensor utilizado nesta tese. São apresentados sucintamente, também, os princípios de detecção usados em biossensores.

\subsection{Biossensores}

Uma definição genérica de um biossensor é de ser um dispositivo para detectar uma substância, que combina um componente biológico com um componente detector físico-químico. Os biossensores são compostos basicamente por: i) um elemento de reconhecimento biológico (enzimas, anticorpos, organelas, células, DNA etc.), que interage de modo específico com a substância de interesse (analito) e ii) um transdutor que converte a resposta biológica em sinal apropriado, segundo o princípio físico-químico de transdução (STRADIOTTO; YAMANAKA; ZANONI, 2003). Biossensores podem ser classificados conforme o processo de transdução: óptico, acústico, eletroquímico, calorimétrico e magnético, ou de acordo com o elemento de reconhecimento biológico, como células, enzimas, anticorpos, ácidos nucléicos (EDSON GIULIANI RAMOS FERNANDES, 2005). Os biossensores podem também ser classificados quanto à afinidade com os analitos. Há biossensores que apresentam bioafinidade e os bioanalíticos. Nos biossensores com bioafinidade há uma dependência da ligação seletiva do analito-alvo imobilizado na superfície do eletrodo, por exemplo anticorpo ou sonda de ácidos nucleicos. Nos bioanalíticos, uma enzima é imobilizada e usada como reconhecimento do substratoalvo (WANG, 2000). Seu uso traz uma série de vantagens, pois são altamente 
sensíveis e seletivos, relativamente simples para fabricar, além de acessíveis e prontos para aplicação.

As dificuldades no uso de biossensores incluem problemas de interferência, estabilidade e transferência de elétrons ineficaz nos casos de detecção por técnicas eletroquímicas (MEHRVAR; ABDI, 2004). A detecção dos biossensores pode ser direta, na qual o sinal obtido é a resposta direta da interação biológica, como receptores celulares e anticorpos. Na detecção indireta são usados elementos catalíticos, como enzimas, de maneira que o sinal medido resulta de uma reação catalítica. O sistema de deteç̧ão indireto apresenta maior estabilidade e é mais simples de usar. No entanto, o sistema de detecção direto apresenta maior sensibilidade, menor tempo de operação e baixo custo (MEHRVAR; ABDI, 2004).

\subsubsection{Estrutura de um biossensor}

Os biossensores são constituídos basicamente por um sistema de reconhecimento molecular (biorreceptor), um transdutor $\mathrm{e}$ uma unidade processadora de sinal, como ilustrado na Figura 1 (LEE et al., 2008). O biorreceptor é a parte do biossensor que entra em contato com o analito de interesse, produzindo um sinal. Pode ser uma enzima, anticorpo, ácido nucleico, aptâmero, entre outros (CHAMBERS et al., 2008; LEE et al., 2008; PATHAK; KATIYAR; GIRI, 2007). Os métodos mais utilizados para imobilização desses biorreceptores são adsorção física (interações iônicas e ligações de hidrogênio), ligação cruzada (reticulação), oclusão ou aprisionamento, ligação covalente, encapsulamento e microencapsulamento. Um dos principais fatores para obter um biossensor com alta sensibilidade e confiabilidade é a estabilidade das moléculas, preservando os sítios ativos (MEHRVAR; ABDI, 2004; YANTASEE et al., 2007). O transdutor age como uma interface, medindo a mudança física ou química que ocorre na reação com o biorreceptor, transformando essa mudança em grandeza mensurável, como massa, carga, calor ou luz. Podem ser de diversos tipos, tais como, eletroquímico, óptico, piezoelétrico e calorimétrico (LEE et al., 2008; MEHRVAR et al., 2000; PATHAK; KATIYAR; GIRI, 2007). A unidade processadora de sinal funciona como um detector que filtra, amplifica e analisa o sinal transduzido, transferindo-o para um monitor ou 
armazenando-o em algum dispositivo (PATHAK; KATIYAR; GIRI, 2007; RAITERI; GRATTAROLA; BERGER, 2002).

Figura 1: Representação esquemática de um biossensor. Diferentes elementos de biorreconhecimento e transdutores estão representados.

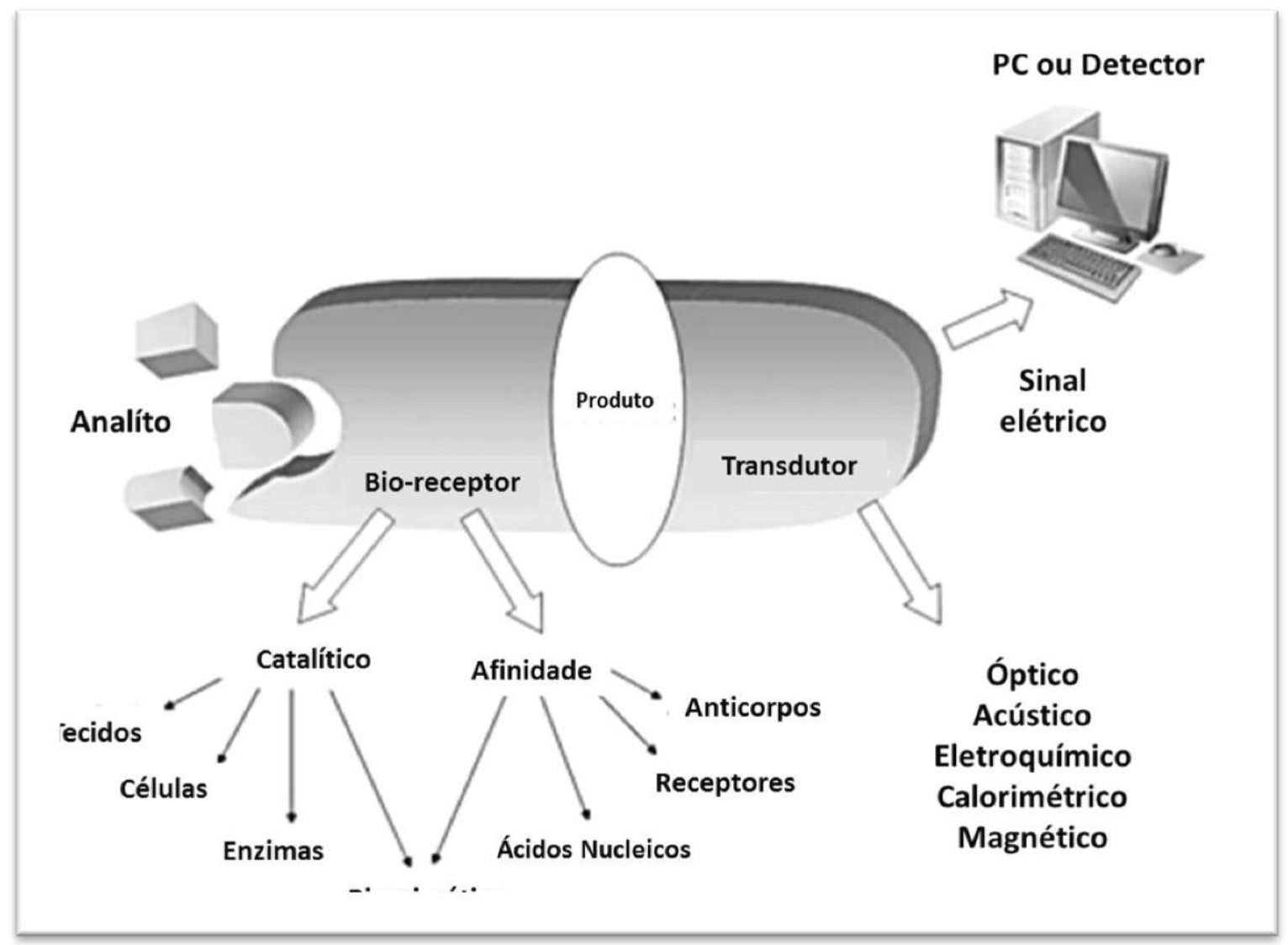

Fonte: Adaptada de MASCINI, et al. 2008

\subsection{Genossensores}

Genossensores são biossensores que possuem como detectores biológicos sequências de ácidos nucleicos (DNA) imobilizados num transdutor (LABUDA et al., 2010). O princípio básico de funcionamento de um genossensor é o reconhecimento da molécula-alvo a partir de hibridização, formando a chamada dupla hélice. A hibridização da sequência de DNA (sonda) é mais forte e específica quando o grau de complementaridade for maior entre as bases nitrogenadas das duas cadeias (PALEČEK; BARTOŠíK, 2012; TELES; FONSECA, 2008). Em um transdutor o 
mecanismo de hibridização sobre um suporte sólido ainda não é bem conhecido e pouco previsível, pois são necessários métodos de monitoramento contínuo e há dificuldade de estimar a concentração da sequência imobilizada (FERNANDO SÉRGIO ROFRIGUES RIBEIRO TELES, 2006). Grande parte dessa menor eficiência de hibridização é devida à indisponibilidade de grupos da cadeia imobilizada na superfície do transdutor, dificultando o processo da ligação da sequência complementar. Outro fator que diminui essa eficiência é o aumento da estrutura secundária de uma ou duas cadeias, ou seja, uma estrutura com maior número de bases nitrogenadas. Para que se obtenha máxima hibridização é necessário otimizar as condições de medida, tais como a força iônica e a temperatura (WANG, 2000). A seletividade e a sensibilidade dependem da hibridização das sequências e a minimização da adsorção não específica (WANG, 2002).

Os ácidos nucleicos (DNA), assim como os anticorpos e enzimas, formam camadas de reconhecimento biológico. São facilmente sintetizados em laboratório, estáveis em alta temperatura e reutilizáveis após a ruptura da dupla hélice (WANG, 2000). Assim, sequências curtas de DNA sintético são mais utilizadas como elementos ativos em genossensores (PANIEL et al., 2013), pois evitam mudanças conformacionais que diminuem a seletividade, sensibilidade e velocidade de hibridização.

Genossensores têm sido usados para diagnóstico de doenças, como câncer, pois possibilitam detecção precoce pela identificação dos genes com sonda de DNA. Isso não é possível obter com imunossensores, pois a doença já é existente para que os anticorpos específicos sejam produzidos e assim detectados (DIAMOND, 1999).

\subsubsection{Elementos de biorreconhecimento dos genossensores}

A especificidade do genossensor depende principalmente das propriedades do elemento de biorreconhecimento. Segundo relatório da União Internacional de Química Pura e Aplicada - IUPAC (2010), estão disponíveis vários sequenciamentos de ácidos nucleicos para biorreconhecimento, como as moléculas de DNA e RNA, PNA (ácido nucleico peptídico) e aptâmero (BORA, 2013; LABUDA et al., 2010; 
PALEČEK; BARTOŠÍK, 2012).

\subsubsection{1 Ácidos nucleicos e aptâmeros}

O ácido nucleico (DNA) é um polímero formado por monômeros chamados nucleotídeos, no qual a cadeia principal é constituída de moléculas de açúcar e fosfato unidos por ligações fosfodiéster (Figura 2). Ligada à molécula de açúcar está uma de quatro bases nitrogenadas, que são adenina $(A)$, timina $(T)$, guanina $(G)$ e citosina (C) e somente no RNA (ácido ribonucleico) a T é substituída por uracila (U). A molécula de DNA é composta por duas fitas, a dupla hélice, ligadas por interações de hidrogênio nas bases nitrogenadas (FENG et al., 2019). As interações são específicas, ligando uma purina com uma pirimidina, ou seja, A pareia com T e C pareia com G. A hibridização com a fita complementar ocorre de forma antiparalela, com a sonda no sentido 5'- 3' pareando com a sequência complementar no sentido 3'- 5' (LEHNINGER; NELSON; COX, 2006).

A estrutura do DNA é mais estável que a do RNA, devido à maior probabilidade de o RNA sofrer hidrólise no grupo 2-OH na pentose (açúcar). No entanto, mesmo sendo mais estável, o DNA pode sofrer mutações, que podem ser somáticas ou germinativas. As mutações somáticas ocorrem quando células se duplicam dando origem a uma população de células mutantes; já a mutação germinativa acontece em células que formam gametas, e pode ser passada de geração em geração. São somáticas as mutações que dão origem ao câncer, com crescimento descontrolado de células gerando os tumores. Determinadas mutações são indicadores de predisposição ao câncer (ALEXANDROV et al., 2013). 
Figura 2: Estrutura dos nucleotídeos.

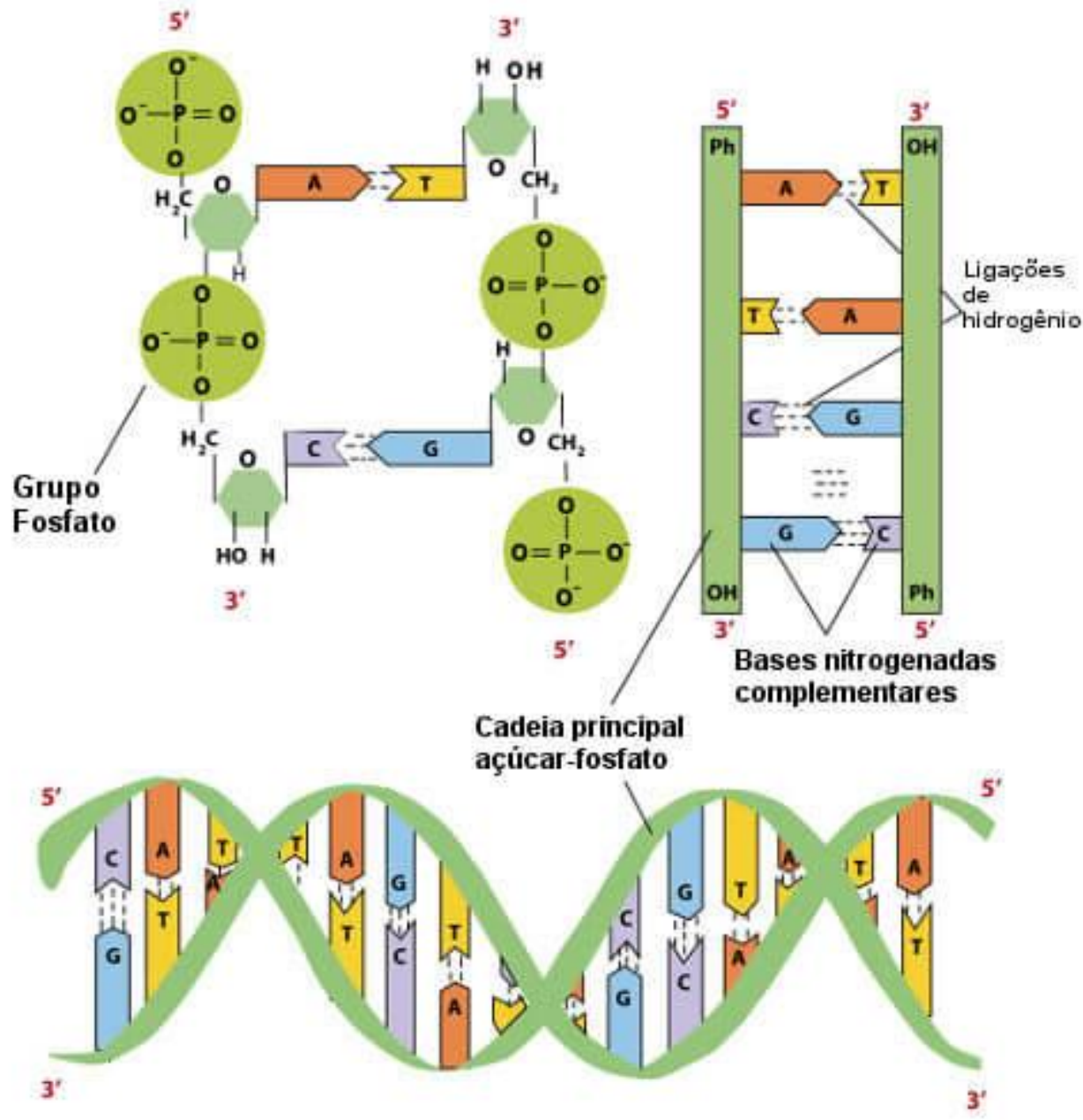

Adenina (A) $\sum$ Timina (T) $\square$ Guanina (G) $\square$ Citosina (C)

Fonte: (ESCOLA, 2019) 


\subsubsection{Principais métodos de imobilização em genossensores}

Um dos principais passos para construir um genossensor é a forma de imobilização das sondas à superfície do eletrodo, que depende do tipo e da natureza do transdutor. Têm sido desenvolvidos métodos para a imobilização de DNA, destacando-se: (i) adsorção física, (ii) adsorção química, (iii) ligação por afinidade e (iv) ligação covalente (LABUDA et al., 2010).

i) Adsorção física é o método mais simples de imobilização, pois não há necessidade de modificações no DNA (E.OLIVEIRA et al., 2013). Este método se caracteriza pelas interações das cargas negativas da sonda de ácidos nucleicos e cargas positivas na superfície do eletrodo (MONOŠíK; STREĎANSKÝ; ŠTURDÍK, 2012). No método de adsorção direta, a sonda é imobilizada diretamente no eletrodo de duas maneiras: (a) imersão do eletrodo em solução, com a sonda dissolvida em solvente apropriado, formando um filme fino de ácidos nucleicos ou evaporando um pequeno volume dessa solução na superfície do eletrodo, criando camadas mais espessas de ácidos nucleicos (LABUDA et al., 2010); (b) numa cela eletroquímica, aplica-se um potencial controlado numa solução contendo a sonda e o eletrodo de trabalho (LABUDA et al., 2010; SASSOLAS; LECA-BOUVIER; BLUM, 2008). O método de adsorção indireta consiste na imobilização da sonda sobre uma fina camada polimérica formada na superfície do eletrodo de trabalho, sendo esse polímero carregado positivamente formando um complexo estável com os grupos fosfato do ácido nucleico, que possuem cargas negativas (LABUDA et al., 2010; TELES; FONSECA, 2008);

ii) Adsorção química: Este método se baseia na formação de filmes nanoestruturados (self-assembled monolayer - SAM) na qual existe forte interação do substrato com os adsorbatos. Os adsorbatos mais utilizados em genossensores são os alcanotióis, pois apresentam afinidade pelo ouro (Au) (SASSOLAS; LECABOUVIER; BLUM, 2008). O principal objetivo com essas moléculas é funcionalizar o substrato para fixar moléculas biológicas. Um exemplo clássico é o do aminoácido cisteína (WANG; WANG; LU, 2012; YANG; JUSTIN GOODING; BRYNN HIBBERT, 2001). A estrutura de um alcanotiol é formada por enxofre ("cabeça"), e a cadeia ("corpo") pode apresentar diferentes quantidades de grupo metileno $\left(\mathrm{CH}_{2}\right)$ e uma extremidade "livre" com grupo terminal específico para a 
imobilização de moléculas biológicas. Esses grupos terminais podem ser $(-\mathrm{COOH}$, $\mathrm{SH},-\mathrm{OH}, \mathrm{e}-\mathrm{CH}_{3}$ ). No decorrer do processo de adsorção é fundamental que essas moléculas formem uma camada organizada. Essa organização inicia-se pelas interações de van der Waals entre moléculas vizinhas, e por isso espera-se que SAMs de cadeia longa apresentem maior organização (BAIN et al., 1989; BAIN; EVALL; WHITESIDES, 1989);

iii) Ligação por afinidade: Um exemplo prático deste método é o complexo avidina (ou estreptavidina)-biotina, em que a biotina tem alta afinidade com os quatros sítios ligantes da avidina ou estreptavidina. Para construir um genossensor desse tipo é necessário modificar a extremidade $5^{\prime}$ da sonda com biotina e o eletrodo de trabalho ser modificado com a avidina ou estreptavidina. O eletrodo é então imerso em uma solução contendo sonda modificada;

iv) Ligação covalente: Neste método, a sonda é modificada na extremidade 5' com grupos funcionais reativos que possuem afinidade com 0 eletrodo de trabalho (MONOŠíK; STREĎANSKÝ; ŠTURDÍK, 2012). Este método tem a vantagem de diminuir etapas de preparação do genossensor e gerar filmes bastante estáveis, aumentando a sensibilidade de detecção ao favorecer a formação da dupla hélice (hibridização). Além disso, nesse método é mais difícil ocorrer ligação de moléculas não específicas na superfície do eletrodo (LABUDA et al., 2010; MONOŠíK; STREĎANSKÝ; ŠTURDÍK, 2012).

\subsubsection{Princípios dos métodos de detecção eletroquímica em genossensores}

A detecção eletroquímica tem se mostrado versátil em análise de ácidos nucleicos e detecção em baixas concentrações (PALEČEK; BARTOŠíK, 2012). O objetivo com um genossensor é o reconhecimento da sequência alvo de ácidos nucleicos, no que se chama de hibridização com formação da dupla hélice. Existem duas maneiras para se observar esse evento: (i) detecção direta, que é a medição da resposta elétrica da sequência alvo ou (ii) método indireto, no qual são monitorados compostos unidos à dupla hélice (PEDRERO; CAMPUZANO; PINGARRÓN, 2011).

i) Método de detecção direta: Por meio da oxidação das bases nitrogenadas 
dos ácidos nucleicos, é observada a mudança no sinal eletroquímico (HVASTKOVS; BUTTRY, 2010). A guanina é a base que apresenta maior eletroatividade e maior facilidade de ser oxidada, sendo por isso a mais adequada para detectar a hibridização (PALEČEK; BARTOŠÍK, 2012). Um fator que pode melhorar a detecção do sinal da oxidação da guanina quando se usam amostras reais é a utilização de sondas (elemento de biorreconhecimento) sem guanina, que pode ser trocada pela base inosina (TOSAR; BRAÑAS; LAÍZ, 2010). Essa base não está presente no DNA, mas apresenta o mesmo comportamento da guanina, de ser oxidada e de se ligar à citosina (LABUDA et al., 2010; PALEČEK; BARTOŠÍK, 2012). A maior eficiência na detecção do sinal de oxidação das guaninas no DNA da amostra biológica se deve à diferença de potencial da oxidação dessas duas bases. O potencial de oxidação da inosina é de cerca de $0,7 \mathrm{~V}$, enquanto para a guanina é de 0,9 a 1,07 V (TOSAR; BRAÑAS; LAÍZ, 2010; WANG et al., 2008). Com isso é possível distinguir com eficácia o sinal de oxidação produzido pela sonda e o sinal de oxidação produzido quando o DNA alvo hibridiza com a sonda (E. FERAPONTOVA, 2011).

ii) Método de detecção indireta: consiste na detecção de moléculas com propriedades redox, permitindo monitorar de forma indireta a estrutura dos DNAs na superfície do eletrodo. Essas moléculas se ligam à estrutura do DNA de fita simples (ss-DNA) ou hibridizado (ds-DNA) de maneiras diferentes, gerando sinais eletroquímicos que podem ser distinguidos, e assim permitindo distinguir as duas estruturas (HVASTKOVS; BUTTRY, 2010). Os compostos mais utilizados para este método são o azul de metileno (AM) e o ferroceno, pois apresentam atividade redox que pode ser estudada por técnicas eletroquímicas (GRIESHABER et al., 2008). O AM é uma molécula heterocíclica aromática com afinidade pelas bases de guanina (PAN et al., 2007). A distinção entre a fita simples (ss-DNA) e a fita dupla (ds-DNA) acontece pela diferença do sinal redox do azul de metileno ligado na estrutura do DNA. O sinal redox será maior na fita simples do que na fita dupla, pois a quantidade de guanina disponível é maior, facilitando a ligação do azul de metileno com o DNA (FARJAMI et al., 2010; ORTIZ et al., 2011). Ao contrário do azul de metileno, o ferroceno interage com maior facilidade com a cavidade do DNA hibridizado (dsDNA) do que com o DNA fita simples (ss-DNA), apresentando então maior sinal eletroquímico para o ds-DNA (RIBEIRO TELES; FRANÇA DOS PRAZERES; DE LIMA-FILHO, 2007). 


\subsection{Espectroscopia de Impedância Eletroquímica}

$\mathrm{Na}$ EIS (Electrochemical Impedance Spectroscopy) um potencial senoidal é aplicado ao sistema sob análise, gerando uma corrente também de natureza oscilatória. Através do monitoramento do potencial e da corrente, obtém-se a impedância, que é uma grandeza complexa, representada por seu módulo e o ângulo de fase (defasagem do potencial aplicado em relação à corrente). Em sistemas eletroquímicos vários processos podem ser descritos pela relação entre a corrente e o potencial aplicado. A partir das medidas da impedância e do ângulo de fase é possível avaliar processos como transporte de carga, condutividade de filmes, capacitância redox e de dupla camada elétrica, e coeficientes de difusão de portadores de carga (JIANG; KUCERNAK, 2002).

Os dados de impedância eletroquímica podem ser interpretados por meio de modelos matemáticos ou circuitos elétricos equivalentes. Estes últimos simulam o comportamento da célula eletroquímica com um circuito elétrico composto de resistores e capacitores, como ilustrado na Figura 3a. Não são em geral incluídos indutores nos circuitos equivalentes, pois na maioria dos problemas tratados com espectroscopia de impedância eletroquímica os fenômenos magnéticos são desprezíveis. A associação em paralelo entre um resistor $\left(R_{c t}\right)$ e um capacitor $(C)$ representa a resistência à transferência de carga na interface eletrodo/solução e a dupla camada elétrica a um capacitor de placas paralelas, respectivamente (RIBEIRO; SOUZA; ABRANTES, 2015). Como a corrente na interface eletrodo/solução é conduzida pelos íons em solução, o efeito resistivo na solução sobre a migração dos íons é representado por uma resistência $R_{\Omega}$. $A$ adição de elementos capacitivos no circuito causa defasagem entre a corrente e o potencial. A impedância tem representação na forma complexa através de uma componente real (resistiva) e uma imaginária (capacitiva). Para o circuito equivalente da Figura $\mathbf{3 b}$, as componentes real (Z') e imaginária (Z") da impedância são (CHINAGLIA et al., 2008):

$$
Z^{\prime}=R_{\Omega}+\frac{R_{c t}}{1+\omega^{2} C^{2} R_{c t}^{2}} e Z^{\prime \prime}=\frac{\omega C R_{c t}^{2}}{1+\omega^{2} C^{2} R_{c t}^{2}}
$$

$R_{\Omega}$ é a resistência da solução, $R_{c t}$ é a resistência à transferência de carga, $\omega$ é 
frequência angular e C é a capacitância da dupla camada elétrica.

Figura 3: (a) Célula eletroanalítica de três eletrodos: (1) Contra-eletrodo, (2) Referência e (3) Trabalho; (b) Circuito equivalente para descrever comportamento eletrodo/solução; (c) Diagrama de Nyquist referente ao circuito equivalente; (d) Diagrama de Bode.

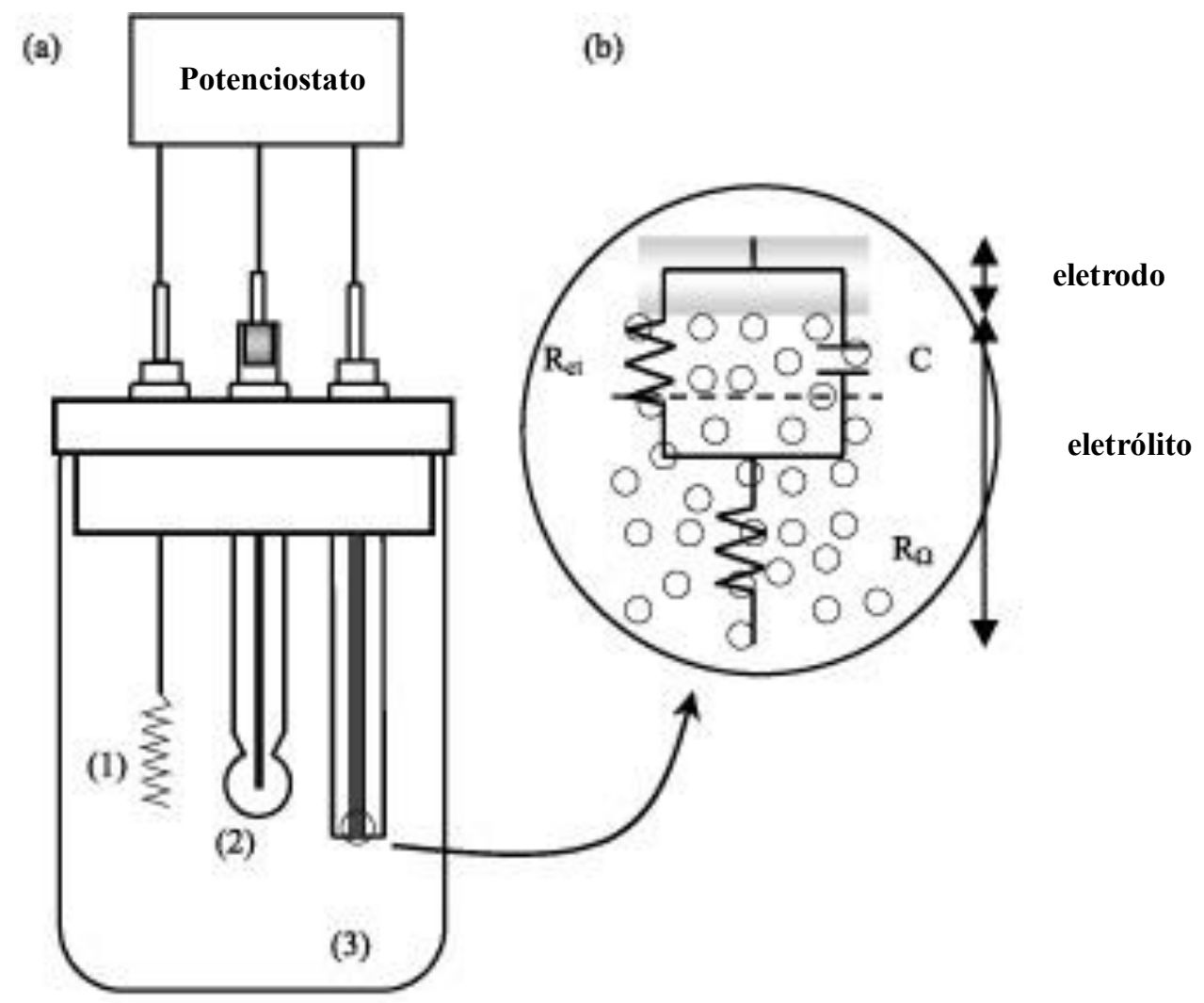

(c)

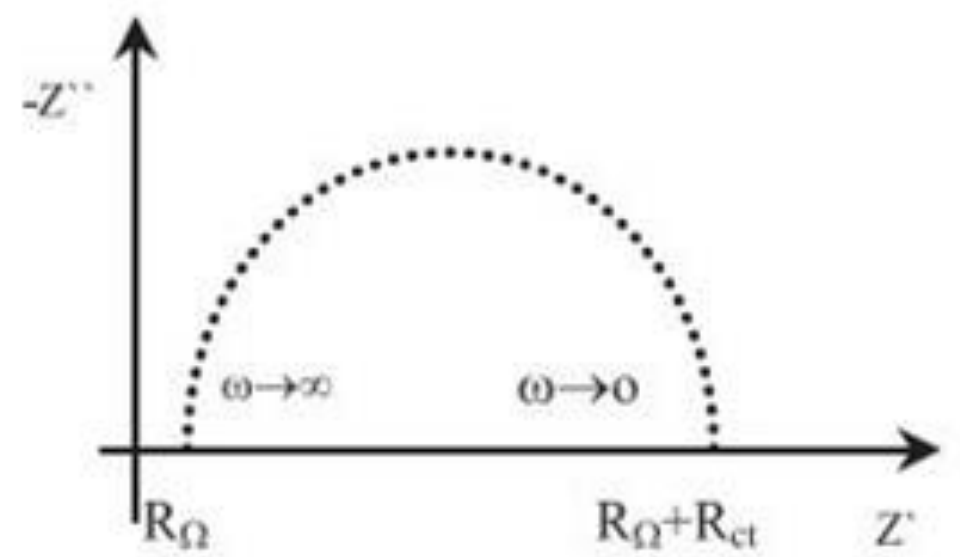

(continua) 


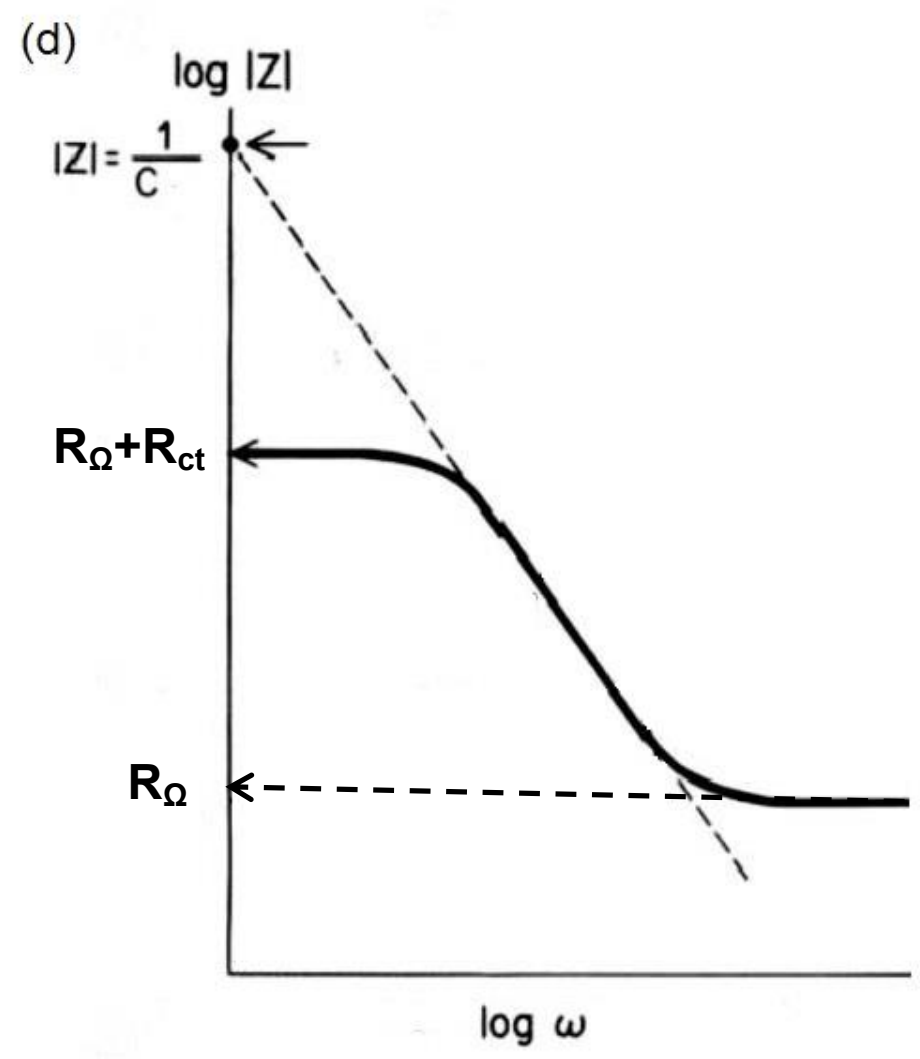

Fonte: Adaptado de (DAMOS; MENDES; KUBOTA, 2004);(MELO; MAIA, 2015).

Segundo a equação [1], na região de alta frequência a componente real da impedância tende a $R_{\Omega}$, enquanto na região de baixa frequência tende a $R_{\Omega}+R_{c t}$. Nestes casos podem-se avaliar os processos de transferência de carga do eletrodo. Sob outra perspectiva, eliminando a frequência nas equações anteriores obtém-se a relação entre a componente imaginária e real da impedância, apresentada a seguir:

$$
\left(Z^{\prime}-R_{\Omega}-\frac{R_{c t}}{2}\right)^{2}+Z^{\prime \prime 2}=\left(\frac{R_{c t}}{2}\right)^{2}
$$

A equação [2] se aplica ao gráfico da Figura 3c que é denominado de diagrama de Nyquist. Na Figura $\mathbf{3 d}$, a representação gráfica do $\log |Z|$ vs. $\omega$ é denominada de diagrama de Bode, com informações complementares ao diagrama de Nyquist. À medida que a frequência aumenta nota-se uma alteração no ângulo de fase entre o potencial aplicado e a corrente resultante. Esta alteração traz informações sobre a componente capacitiva do sistema, uma vez que as 
componentes capacitivas introduzem um comportamento cossenoidal na corrente (SLUYTERS-REHBACH; SLUYTERS, 1969). Assim, a partir dos circuitos elétricos equivalentes, obtêm-se informações sobre a transferência de carga $\left(R_{c t}\right)$, dupla camada $(C)$ e sobre os efeitos da solução na migração dos íons $\left(R_{\Omega}\right)$.

Nos sistemas com efeitos significativos de transferência de massa $\left(Z_{m}\right)$, a introdução de um elemento denominado "Impedância de Warburg" visa a simular as características do sistema experimental, tanto em processos que sofrem difusão linear, esférica ou sob convecção forçada. Neste contexto, um grande conjunto de fatores pode influenciar a impedância do sistema, como processos faradaicos, adsorção de espécies eletroativas e não-eletroativas, reações no eletrodo com formação de intermediários estáveis e heterogeneidade de superfícies. Por isso, a EIS é útil em amplo campo de aplicações. 


\section{CAPÍTULO 3- MATERIAIS E PROCEDIMENTOS EXPERIMENTAIS}

\subsection{Materiais}

Neste trabalho foram utilizados água Milli-Q, tampão fosfato salino (PBS) consistindo de $\mathrm{NaCl} 137 \mathrm{mM}, \mathrm{Na}_{2} \mathrm{HPO}_{4} 10 \mathrm{mM}, \mathrm{KH}_{2} \mathrm{PO}_{4}$ 1,7 mM, KCl $2.7 \mathrm{mM}$, pH de 7.4) com adição de $\mathrm{MgCl}_{2}(1 \mathrm{mM})$ adquirido da Synth, ácido mercaptoacético (MAA) (50 mM), ácido 11- Mercaptoundecanóico (MUA) (50 mM) da Sigma Aldrich, etanolamina (1 $\mathrm{mM})$ da Sigma Aldrich, hidrocloreto de 1-etil-3-[3dimetilaminopropil] carbodiimida (EDC) (400 mM) e N-hidroxisuccinimida (NHS) (100 mM), da Sigma Aldrich. Para a limpeza dos substratos de ouro foi utilizado etanol, acetona e solução Piranha $\left(50 \% \mathrm{H}_{2} \mathrm{SO}_{4}: 50 \% \mathrm{H}_{2} \mathrm{O}_{2}\right)$. Na caracterização eletroquímica foram usados 5 $\mathrm{mM}$ de ferrocianeto e ferricianeto de potássio $\left(\mathrm{K}_{3}\left[\mathrm{Fe}(\mathrm{CN})_{6}\right] / \mathrm{K}_{4}\left[\mathrm{Fe}(\mathrm{CN})_{6}\right]\right)$ da Sigma Aldrich em solução $1 \mathrm{mM}$ de $\mathrm{PBS} / \mathrm{MgCl}_{2}$. Os DNAs usados neste trabalho foram sintetizados pela Sigma Aldrich, com as seguintes sequências:

Sonda DNA ( $\mathrm{NH}_{2}$-SSDNA) com 24 bases: 5' - $\mathrm{NH}_{2}-\left(\mathrm{CH}_{2}\right)_{6}-\mathrm{TTT}$ CGC AAA CGA TAC GCA CCG CGA - 3'

Sequência complementar (ds-DNA) com 21 bases: 5' - TCG CGG TGC GTA TCG TTT GCG - 3'

Sequência complementar com 1 base trocada (1b-DNA), com 21 bases: 5' TCG CGG TGC GGA TCG TTT GCG - 3'

Sequência não complementar (nc-DNA), com 21 bases: 5' - CGA GAA CTT ACG GTC CCC TTA - 3'

Foram usadas amostras de linhagens celulares HN13 (97\%), JHU28 (93\%), FaDu (3\%) e SCC25 (2\%) com diferentes porcentagens de metilação. 
Tabela 1: Comprimento da sequência de DNA e comparação com comprimentos de Mercaptos.

\begin{tabular}{ccc}
\hline & $\begin{array}{c}\text { Comprimento } \\
(\mathbf{n m})\end{array}$ & Referências \\
\hline DNA (20 pb) & 6,8 & (ALBERTS et al., 2014) \\
MPA (Ácido 3-Mercaptorpopiônico) & 0,68 & $\begin{array}{c}\text { (HINTERWIRTH et al., } \\
\text { 2013) }\end{array}$ \\
$\begin{array}{c}\text { MUA (Ácido 11- } \\
\text { Mercaptoundecanoico) } \\
\text { MHA (Ácido 16- } \\
\text { mercapohexadecanoico) }\end{array}$ & 2,35 & $\begin{array}{c}\text { (HINTERWIRTH et al., } \\
\text { 2013) }\end{array}$ \\
\hline
\end{tabular}

Fonte: Elaborada pela autora

\subsection{Preparação dos Eletrodos}

Os eletrodos Cr/Au foram fabricados no Laboratório de Microfabricação (LMF) do Laboratório Nacional de Nanotecnologia (LNNano). As lâminas de vidro de microscopia com dimensões de 5,0 x 7,0 cm de largura e comprimento foram limpas com detergente neutro Extran ${ }^{\circledR}$ para remoção de impurezas; em seguida enxaguadas com água Milli-Q e etanol. As lâminas foram então recobertas com uma camada de $20 \mathrm{~nm}$ de cromo (Cr) e outra de $150 \mathrm{~nm}$ de ouro (Au) por Sputtering (BALZERS BA510). Esses eletrodos de ouro foram lavados em água corrente e detergente, seguido de limpeza com acetona, etanol e água Milli-Q. Foram posteriormente colocados em solução Piranha (1:1) por 30 minutos e limpos eletroquimicamente em solução $0,1 \mathrm{M}$ de $\mathrm{H}_{2} \mathrm{SO}_{4}$ por voltametria cíclica em potencial aplicado de 0 a $0,9 \mathrm{~V}$ com taxa de $1 \mathrm{mV} / \mathrm{s}$ (60 ciclos), e finalmente secos em fluxo de gás $\mathrm{N}_{2}$. Os eletrodos possuem dimensões de $2,5 \mathrm{~cm} \times 0,7 \mathrm{~cm}$, como mostra a Figura 4. A área geométrica (área circular) do eletrodo foi delimitada usando uma fita dupla face $\left(0,9 \mathrm{~cm}^{2}\right)$. 
Figura 4: Eletrodo de ouro com área delimitada

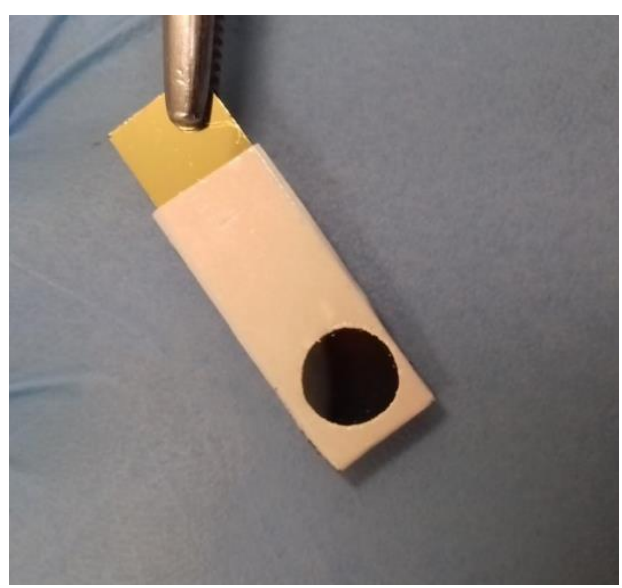

Fonte: Elaborada pela autora

\subsection{Fabricação dos Genossensores}

$\mathrm{Na}$ fabricação dos genossensores, foram preparadas duas plataformas imobilizando na superfície do eletrodo uma monocamada automontada (SAM) preparada em etanol por $24 \mathrm{~h}$ em uma solução contendo $50 \mathrm{mM}$ de ácido mercaptoacético (MAA) e outra ácido 11-Mercaptoundecanóico (MUA), em temperatura ambiente. Os eletrodos foram imersos na solução de EDC/NHS por 30 minutos e depois lavados em água Milli-Q. A sonda $\mathrm{NH}_{2}$-ssDNA foi diluída em solução de $\mathrm{PBS} / \mathrm{MgCl}_{2}(1 \mathrm{mM})$ em concentração de $1 \mu \mathrm{M}$ e imersa por $2 \mathrm{~h}$ nesta solução, à temperatura ambiente (Figura 5). Seguiu-se lavagem com água ultrapura (Milli-Q). Para a hibridização foram realizados experimentos com diferentes concentrações das sequências complementares e não complementares. As variações abrangeram concentrações entre $10^{-12} \mathrm{M}$ a $10^{-6} \mathrm{M}$ diluídas em solução $\mathrm{PBS} / \mathrm{MgCl}_{2}$. A hibridização foi realizada a $86{ }^{\circ} \mathrm{C}$ durante $1 \mathrm{~h}$ e depois colocado em gelo por 5 min. Finalmente, o eletrodo modificado foi limpo com água Milli-Q. 
Figura 5: Esquema da construção do genossensor.

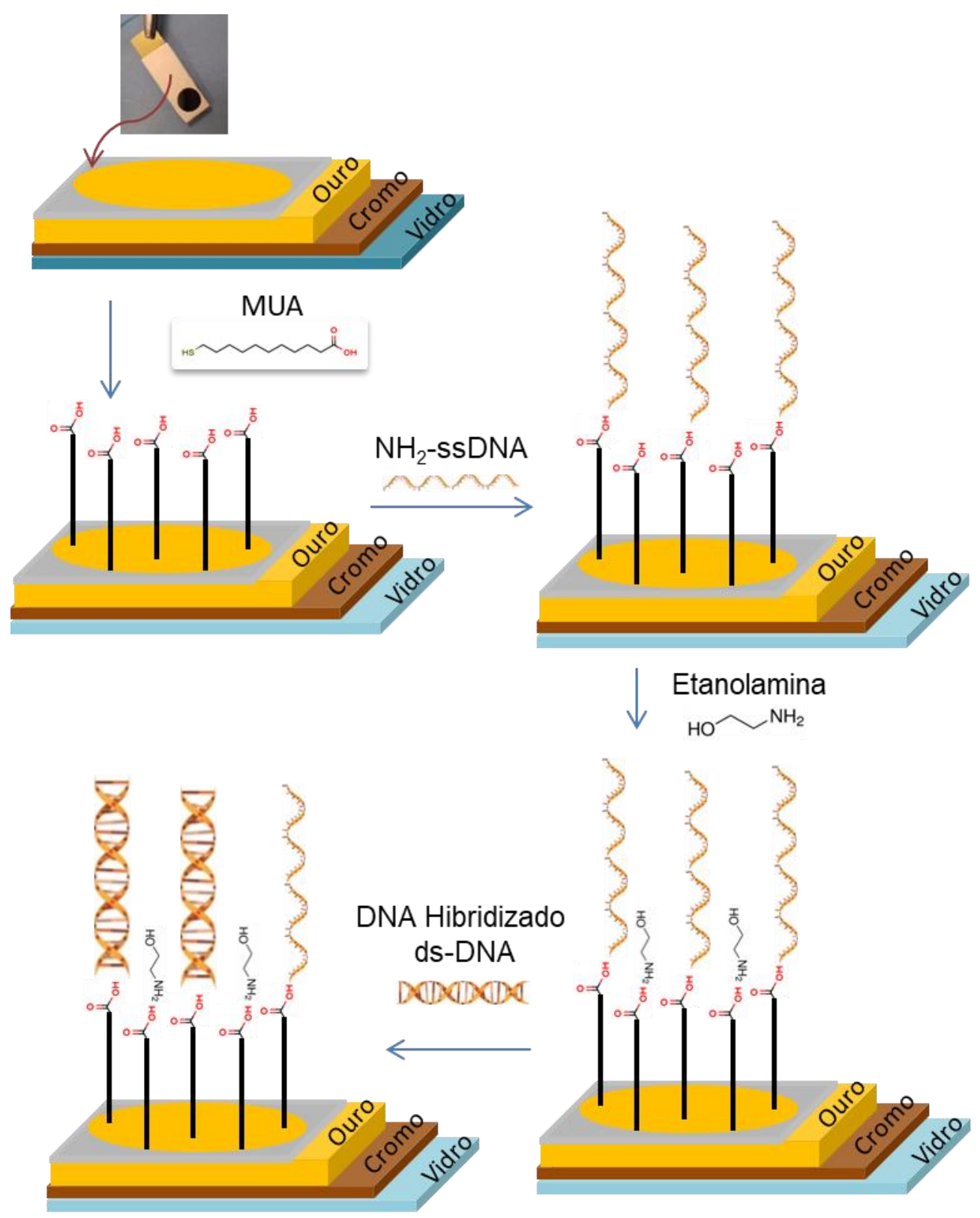

Fonte: Elaborado pela autora.

\subsection{Impedância Eletroquímica}

As medidas eletroquímicas foram realizadas em um potenciostato/galvanostato Autolab PGSTAT 204, gerenciado pelo software Nova, no modo FRA (do inglês, Frequency Response Analyser) versão 2.0. Nesta caracterização eletroquímica foram usados $5 \mathrm{mM}$ de ferrocianeto e ferricianeto de potássio $\left(\mathrm{K}_{3}\left[\mathrm{Fe}(\mathrm{CN})_{6}\right] /\right.$ $\left.\mathrm{K}_{4}\left[\mathrm{Fe}(\mathrm{CN})_{6}\right]\right)$ em $\mathrm{PBS} / \mathrm{MgCl}_{2}(1 \mathrm{mM})$, numa célula eletroquímica com três eletrodos: 
eletrodo de referência $(\mathrm{Ag} / \mathrm{AgCl})$, placa de platina como eletrodo auxiliar $\left(1 \mathrm{~cm}^{2}\right)$ e eletrodo de trabalho de ouro $\left(0,9 \mathrm{~cm}^{2}\right)$. A faixa de frequência foi de $100 \mathrm{kHz}$ a $0,1 \mathrm{~Hz}$, com amplitude AC de $10 \mathrm{mV}$.

\subsection{Espectroscopia de Reflexão-Absorção na Região do Infravermelho com modulação da polarização (PM-IRRAS)}

A espectroscopia PM-IRRAS é usada para a caracterização de filmes finos ou monocamadas em substrato de metal ou sobre a superfície da água, pois possui especificidade para superfícies e interfaces. Nessa técnica podem ser observados espectros vibracionais da interface e assim fazer uma análise dos grupos químicos presentes (MENDELSOHN; MAO; FLACH, 2010). As componentes com polarizações paralela $(p)$ e perpendicular $(s)$ ao plano de incidência são medidas simultaneamente, permitindo obter informações sobre a orientação de dipolos (TOLSTOY; CHERNYSHOVA; SKRYSHEVSKY, 2003). Para um ângulo de incidência de $80^{\circ}$, como na montagem experimental empregada nesta tese, dipolos orientados perpendicularmente à interface são sensíveis à absorção do feixe de luz polarizado paralelo ao plano de incidência, enquanto $\circ$ feixe polarizado perpendicularmente é sensível aos dipolos orientados paralelos à interface. Assim, a diferença fornece informação sobre a orientação dos dipolos constituintes das moléculas na interface.

Neste trabalho foi utilizado o espectroscópio da marca KSV Instruments, Helsinque, Finlândia, modelo PMI 550. Este modelo é composto por uma lâmpada de carbeto de silício, um modulador fotoelástico de cristal de ZnSe (operando em 50 $\mathrm{kHz}$ ) e um detector de $\mathrm{HgCdTe}$, modelo $\mathrm{PCl}-3 \mathrm{TE}-10.6$. As medidas foram realizadas com ângulo de incidência de $80^{\circ}$. 


\section{6 Ângulo de Contato e Energia de Superfície}

O cálculo da energia de superfície pode ser feito pela medida de ângulo de contato, que informa a natureza hidrofílica ou hidrofóbica da superfície. Esse é o ângulo entre um plano tangente de uma gota do líquido e o plano da superfície onde o líquido se encontra, como mostrado na Figura 6.

Figura 6: Definição do ângulo de contato $\theta$ entre uma gota de um líquido e a superfície.

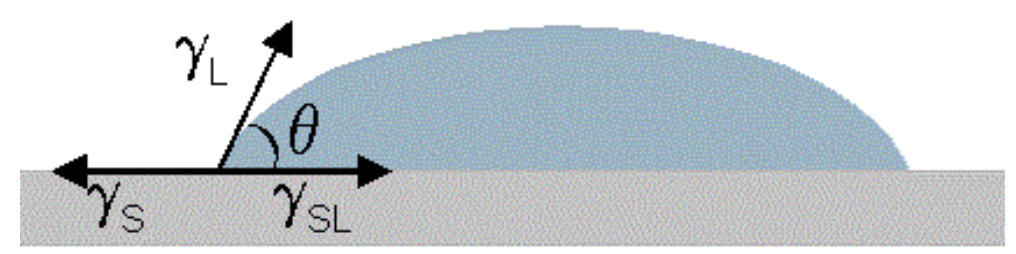

Fonte: (MATERIAIS, 2019)

O conceito de energia de superfície é compreendido usando um líquido como exemplo, pois átomos e moléculas procuram ocupar uma posição de menor energia. Portanto, a energia de superfície é a diferença entre as energias na superfície e no interior do material. Considerando que a gota está em equilíbrio (LUZ; RIBEIRO; PANDOLFELLI, 2008):

$$
\gamma_{S}=\gamma_{S L}+\gamma_{L} \cos \theta
$$

Esta é conhecida como equação de Young, sendo Ys a energia de superfície do sólido, YSL a energia de superfície interfacial entre o sólido e o líquido, e YL a energia de superfície do líquido. $O$ trabalho de adesão, $W_{a}$, o negativo da energia de adesão de Gibbs (RABOCKAI, 1979), entre o sólido e o líquido, pode ser expresso pela equação de Dupré (LUZ; RIBEIRO; PANDOLFELLI, 2008):

$$
W_{a}=\gamma_{L}+\gamma_{S}-\gamma_{S L}
$$


Das equações [3] e [4], obtém-se a equação de Young-Dupré:

$$
W_{a}=\gamma_{L}(\cos \theta+1)
$$

A equação [5] relaciona duas grandezas determináveis com relativa facilidade e precisão, ou seja, o ângulo $\theta$ e a energia de superfície do líquido $\left(\mathrm{YL}_{\mathrm{L}}\right)$. Quando $\theta=$ $0, \cos \theta=1$ então $W_{a}=2 \gamma_{L}$.

A quantidade $2 \gamma_{\mathrm{L}}$ é denominada trabalho de coesão do líquido, sendo o dobro da energia superficial (SELL; NEUMANN, 1966). Portanto, o ângulo de contato igual a zero se observa quando o trabalho de adesão líquido-sólido iguala, ou supera, o trabalho de coesão do líquido. Nesta situação, o líquido se espalha pela superfície sólida. Por outro lado, quando $\theta=180^{\circ}$, tem-se $\cos \theta=-1$ e o trabalho de adesão líquido-sólido é zero. Este é o caso limite quando não há adesão entre as duas fases. A energia de superfície, proposta por Fowkes (FOWKES, 1964), depende das contribuições de interação dispersivas $\left(\mathrm{\gamma}^{\mathrm{d}}\right)$ e polares $\left(\mathrm{\gamma}^{\mathrm{p}}\right)$, além de um fator de correção que envolve a média geométrica entre as componentes dispersivas.

$$
\begin{gathered}
\gamma=\gamma^{d}+\gamma^{p} \\
\gamma_{L}(\cos \theta+1)=2 \sqrt{\gamma_{S}^{d} \gamma_{L}^{d}} \\
W_{a}=2 \sqrt{\gamma_{S}^{d} \gamma_{L}^{d}}
\end{gathered}
$$

Owens, Wendt e Kaelble (OWENS; WENDT, 1969) expandiram a equação de Fowkes para uma forma mais geral $W_{a}=2 \sqrt{\gamma_{s}^{d} \gamma_{L}^{d}}+2 \sqrt{\gamma_{s}^{p} \gamma_{L}^{p}}$ com separação da influência de componentes dispersivas e polares. Combinando a equação [6] e equação de Fowkes, temos:

$$
\gamma_{L}(\cos \theta+1)=2 \sqrt{\gamma_{S}^{d} \gamma_{L}^{d}}+2 \sqrt{\gamma_{S}^{p} \gamma_{L}^{p}}
$$

A equação [9] pode ser rearranjada para que as parcelas polares e as dispersivas da energia de superfície do sólido sejam ajustadas linearmente. 


$$
\frac{(\cos \theta+1) \gamma_{L}}{2 \sqrt{\gamma_{L}^{d}}}=\sqrt{\gamma_{S}^{p}}\left[\frac{\sqrt{\gamma_{L}^{p}}}{\sqrt{\gamma_{L}^{d}}}\right]+\sqrt{\gamma_{S}^{d}}
$$

Nesta tese, a energia livre de superfície foi determinada por meio de uma versão implementada no Microsoft Excel, a partir das equações [7] e [10]. Para caracterização da superfície modificada com a monocamada automontada de MUA e MAA, $\mathrm{NH}_{2}$-ssDNA, ds-DNA, 1b-DNA e nc-DNA. Foram usados 3 solventes (água, formamida e di-iodometano) depositados na superfície com uma microsseringa Hamilton, com gotículas de $3 \mu \mathrm{L}$. Os ângulos foram medidos da imagem produzida com um goniômetro CAM 200, da KSV Instruments, Helsinque, Finlândia. O valor dos ângulos de contato foi calculado da média aritmética de medidas com 3 gotas, fotografadas em 3 frames por segundo. Tais medidas foram realizadas com 0 Software CAM 200.

\subsection{Espectroscopia de Geração de Soma de Frequências (SFG)}

A espectroscopia SFG é uma técnica sensível à superfície baseada em óptica não linear e capaz de fornecer informações sobre a composição e ordenação de moléculas na superfície e na interface. Dois pulsos de laser com alta intensidade são incididos na superfície da amostra, sobrepostos no tempo e na localização. Um tem frequência fixa no visível ( $\left.\omega_{V I S}\right)$ e o outro é sintonizável no infravermelho $\left(\omega_{\mathbb{I}}\right)$, gerando um feixe de saída na frequência $\omega_{\mathrm{SFG}}=\omega_{\mathrm{VIS}}+\omega_{\mathbb{I R}}$. A intensidade do sinal SFG é proporcional à suscetibilidade efetiva não-linear de segunda ordem $\left(\chi_{e f f}^{(2)}\right)$. Por ser um processo de segunda ordem, o SFG só é permitido em meios não centrossimétricos, como interfaces onde a simetria de inversão é quebrada pela introdução de um plano de assimetria. Além disso, a emissão de SFG não é observada com moléculas completamente desordenadas na interface. Portanto, as espécies na interface devem ter uma orientação polar quando o sinal SFG é observado. O sinal SFG pode ser expresso como (MAIA; MIRANDA, 2015) 


$$
I_{S F G} \propto\left|\chi_{e f f}^{(2)}\right|^{2}=\left|\chi_{N R}^{(2)}+\chi_{R}^{(2)}\right|^{2}=\left|\chi_{N R}^{(2)}+N_{S} \sum_{q} \frac{A_{q}}{\omega_{I R}-\omega_{q}+i \Gamma_{q}}\right|^{2}
$$

onde $\chi_{N R}^{(2)}, \chi_{R}^{(2)}, \mathrm{N}_{\mathrm{s}}, \mathrm{A}_{\mathrm{q}}, \omega_{\mathrm{q}}, \Gamma_{\mathrm{q}}$, são as contribuições ressonantes e não ressonantes para $\chi_{e f f}^{(2)}$, a densidade superficial das moléculas e a força do oscilador, freqüência de ressonância e largura de linha do q-ésimo modo vibracional, respectivamente. Portanto, a susceptibilidade efetiva $\chi_{e f f}^{(2)}$ é obtida diretamente do espectro do SFG e fornece informações sobre a composição e orientação das espécies na interface. Detalhes teóricos da espectroscopia SFG podem ser obtidos nas referências (LAMBERT; DAVIES; NEIVANDT, 2005; SHEN, 1994, 2013; ZHANG, 2017; ZHUANG et al., 1999).

Os espectros de SFG foram medidos em uma configuração comercial SFG (EKSPLA, Lituânia) descrita em detalhe nas referências (PAVINATTO et al., 2016; UEHARA et al., 2014). Os pulsos de laser VIS (532 nm, $700 \mu \mathrm{J}$ por pulso) e IR (20$200 \mu \mathrm{J}$ por pulso) são gerados a uma taxa de repetição de $20 \mathrm{~Hz}$. Os feixes incidem na superfície da amostra com ângulos de incidência de $55^{\circ}$ (IV) e $60^{\circ}$ (VIS). Devido às regras de seleção da superfície do ouro, apenas as combinações de polarização contendo o feixe IR polarizado $P$ geram sinal SFG com intensidade apreciável. Assim, os espectros SFG foram obtidos com polarização PPP (SFG polarizado P, VIS polarizado $\mathrm{P}$ e IR polarizado $\mathrm{P}$ ) de 1200 a $1600 \mathrm{~cm}^{-1}$. Cada ponto no espectro representa a média de 100 pulsos com um incremento de $3 \mathrm{~cm}^{-1}$.

\subsection{Métodos de Visualização de Informação}

Os valores de impedância das medidas foram analisados utilizando o software Projection Explorer Sensors (PEx-Sensors) (PAULOVICH et al., 2011). Este software implementa técnicas de projeção muldimensional e de visualização, como os Mapas de Documentos Interativos (IDMAP) e a técnica de Coordenadas Paralelas (PC) (MORAES et al., 2012; PAULOVICH et al., 2011). A primeira técnica considera a distância euclidiana entre o sinal de diferentes amostras $X=\left\{X_{1}, X_{2}, \ldots, X_{n}\right\}$, com 
$\delta\left(x_{i}, x_{j}\right)$ sendo funções de dissimilaridade entre duas amostras i e j. A partir destes dados, as projeções de $X$ são traçadas em um espaço de dimensão inferior, no qual $Y=\left\{y_{1}, y_{2}, \ldots, y_{n}\right)$ é a posição dos elementos visuais (mapeamentos de $X$ ) e $d\left(y_{i}-y_{j}\right)$ é a função da distância de dois quaisquer elementos de mapeamento de $X$. Estas projeções são funções injetoras $f: X \rightarrow Y$, que minimizam o termo $\left|\delta\left(x_{i}, x_{j}\right)-d\left(y_{i}-y_{j}\right)\right| \forall x_{i}, x_{j} \in X$, e é dado pela equação 12 em que $\delta_{\max }$ e $\delta_{\min }$ são a máxima e a mínima distância entre os dados.

$$
S_{I D M A P}=\frac{\delta\left(x_{i}, x_{j}\right)-\delta_{\min }}{\delta_{\text {max }}-\delta_{\min }}-d\left(y_{i}, y_{j}\right)
$$

Nas medidas de impedância elétrica, além do comportamento de um conjunto de amostras, é necessário compreender a resposta do sistema a diferentes frequências. Para isto, foi utilizada a técnica de visualização de coordenadas paralelas (INSELBERG; DIMSDALE, 1990), em que os dados são projetados num gráfico onde eixos paralelos, igualmente espaçados, representam a faixa de frequência da medida. Os valores de impedância são determinados pela intersecção do eixo de frequência nos pontos a serem medidos. Através desta representação visual, observa-se a distribuição dos dados e suas correlações (MORAES et al., 2012; PAULOVICH et al., 2011). 


\section{CAPÍTULO 4- RESULTADOS E DISCUSSÃO}

Os resultados foram divididos em duas partes. Na primeira fez-se uma caracterização do processo de formação dos genossensores, essencial para identificar a arquitetura molecular adequada para o biossensoriamento. Foram usadas diferentes técnicas nessa caracterização. A segunda parte contém as medidas de impedância eletroquímica para confirmar a detecção de um marcador de câncer.

\subsection{Caracterização da Monocamada Automontada (SAM) e do genossensor}

\subsubsection{PM-IRRAS}

A Figura 7 ilustra espectros de PM-IRRAS para diferentes tempos de imobilização da monocamada automontada (SAM) de ácido mercaptoacético (MAA) (50 mM) em etanol. As amostras foram preparadas em substratos de ouro diferentes para os diversos tempos de imobilização, para que as medidas fossem realizadas no mesmo dia e sob as mesmas condições. Como o MAA é uma molécula pequena, pois possui 2 carbonos e terminação com ácido carboxílico, é necessário observar sua organização para construção do genossensor, fundamental para posterior imobilização da sonda de DNA. Na Figura 7 aparecem três bandas características do estiramento dos grupos C-C: estiramento simétrico $\mathrm{v}_{\mathrm{s}}\left(\mathrm{CH}_{2}\right)$ em $2843 \mathrm{~cm}^{-1}$, estiramento assimétrico $\mathrm{v}_{\mathrm{as}}\left(\mathrm{CH}_{2}\right)$ em $2912 \mathrm{~cm}^{-1}$ e estiramento assimétrico $\mathrm{v}_{\mathrm{as}}\left(\mathrm{CH}_{3}\right)$ em $2954 \mathrm{~cm}^{-1}$. Há uma mudança na banda em $2912 \mathrm{~cm}^{-1}$ para menores números de onda na Figura 8 em função do aumento do tempo de imobilização, o que indica aumento da organização do MAA a partir de 30 dias de imobilização (BREWER et al., 2002). Entre as moléculas adsorvidas no substrato, há interações de van der Waals nas cadeias de hidrocarboneto, que induzem organização das moléculas fazendo com que a monocamada se torne mais compacta. Como a organização das moléculas inicia-se com as interações de van der Waals entre moléculas vizinhas, espera-se que SAMs formadas por moléculas de cadeia longa apresentem maior 
estabilidade (AOKI, 2001).

Figura 7: Espectro PM-IRRAS para monocamada automontada (SAM) de ácido mercaptoacético (MAA) imobilizada em diferentes tempos.

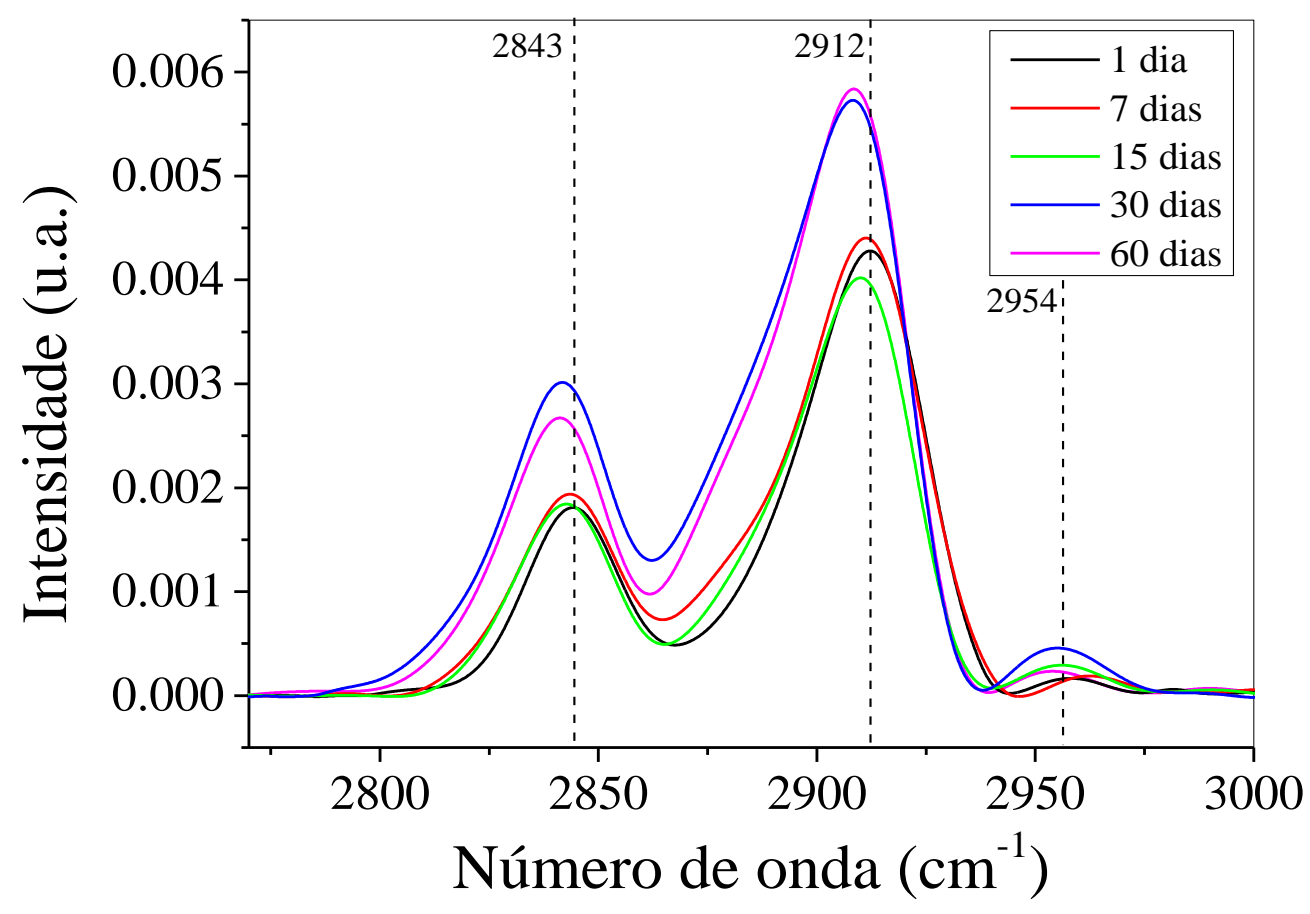

Fonte: Elaborado pela autora. 
Figura 8: Deslocamento da banda $v_{a s}\left(\mathrm{CH}_{2}\right)$ em função do tempo de imobilização no espectro PMIRRAS da monocamada automontada (SAM) de ácido mercaptoacético (MAA).

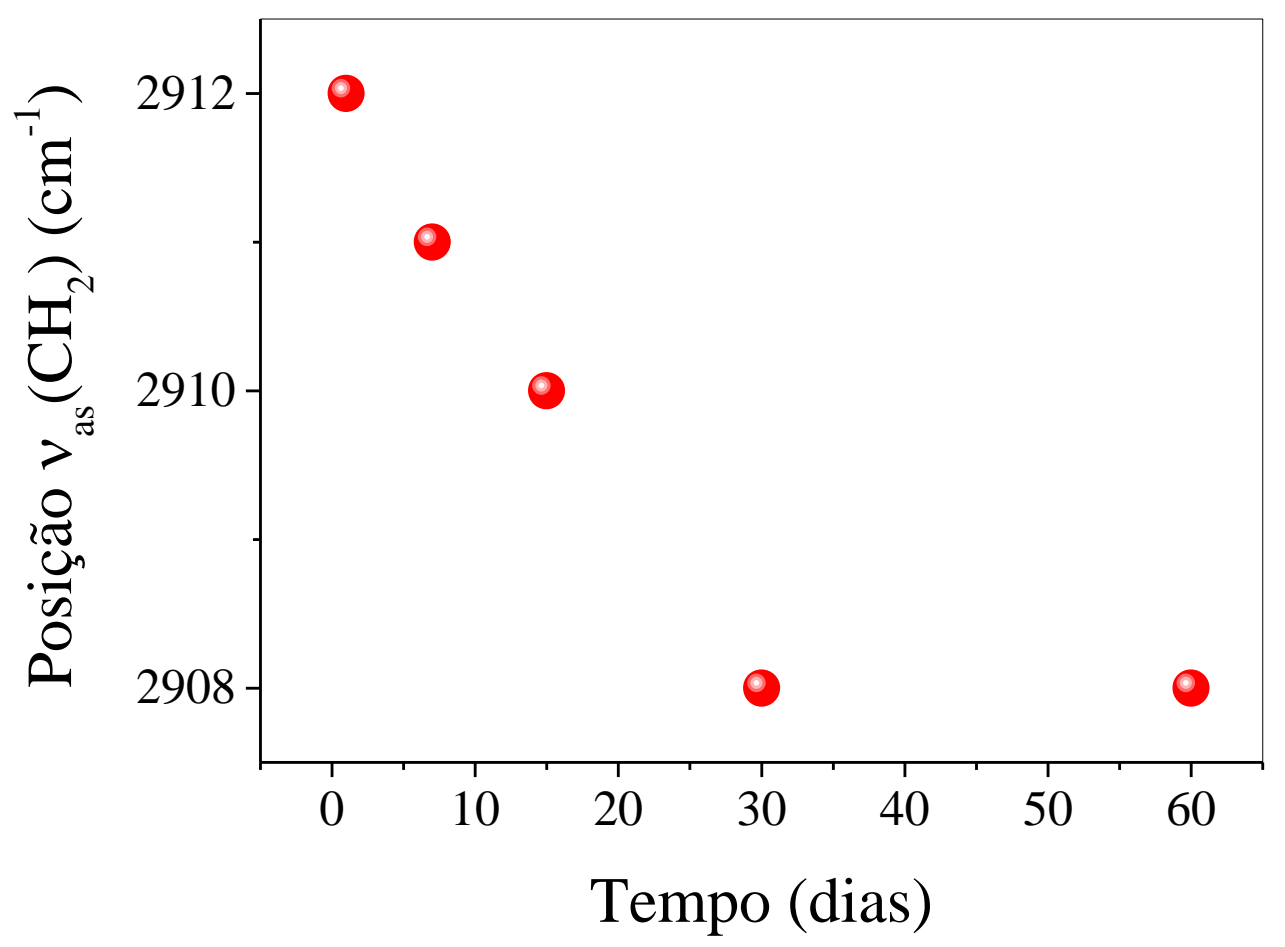

Fonte: Elaborado pela autora.

A Figura 9 apresenta espectros de PM-IRRAS da monocamada automontada (SAM) de ácido mercaptoacético (MAA) e ácido 11-mercarptoundecanóico (MUA) ambos (50 mM) em etanol. Para o MUA, sabe-se da literatura (CASFORD et al., 2014) que o tempo de imobilização e organização da molécula é superior a $20 \mathrm{~h}$. Neste trabalho foi usado o tempo de $24 \mathrm{~h}$. A banda referente ao estiramento assimétrico $\mathrm{v}_{\mathrm{as}}\left(\mathrm{CH}_{2}\right)$ em $2912 \mathrm{~cm}^{-1}$, relacionada à organização da monocamada, coincide para MAA (30 dias) e MUA (1 dia). Ou seja, 1 dia de imobilização do MUA é suficiente para obter uma monocamada aderida e organizada sobre o substrato de ouro, ao contrário de pelo menos 30 dias para o MAA. 
Figura 9: Espectro PM-IRRAS da monocamada automontada (SAM) de ácido mercaptoacético (MAA) e ácido 11-mercaptoundecanóico (MUA) imobilizada em 1 dia e 30 dias.

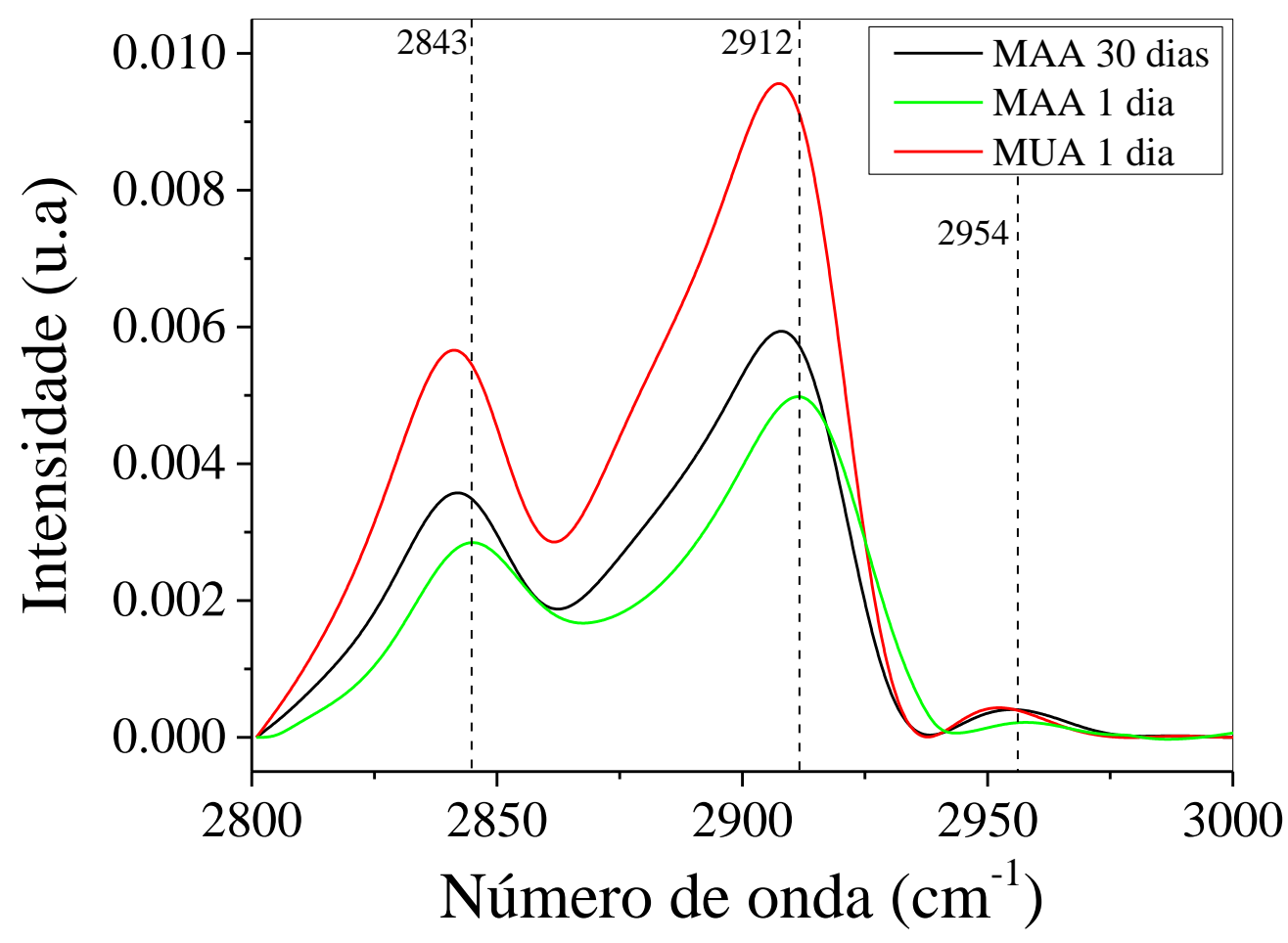

Fonte: Elaborado pela autora.

Os espectros de PM-IRRAS dos DNAs imobilizados sobre o MUA na região de 1600 a $1800 \mathrm{~cm}^{-1}$ estão na Figura 10. O espectro da sonda ( $\mathrm{NH}_{2}$-SSDNA) é mostrado em (a), (b) traz o espectro da sequência complementar (ds-DNA) hibridizada na sonda, e em (c) está o espectro para a sequência não complementar (nc-DNA). Os três espectros apresentaram as mesmas 4 bandas, em 1622, 1646, 1694 e $1745 \mathrm{~cm}^{-1}$. A banda em $1622 \mathrm{~cm}^{-1}$ é atribuída à flexão do $\mathrm{NH}_{2}$ da guanina, a de $1646 \mathrm{~cm}^{-1}$ é atribuída à deformação do anel (estiramento $\mathrm{C}=\mathrm{N}$ ) da citosina e as bandas em 1694 e $1745 \mathrm{~cm}^{-1}$ são atribuídas ao estiramento de carbonila da timina (Tabela 2) (BREWER et al., 2002). Uma forma de diferenciar esses espectros é verificar a área das bandas. Para isso fez-se a deconvolução das bandas, a partir da qual se obteve a largura de banda, área e posição, conforme a Tabela 3. A área das 4 bandas para a sequência complementar (ds-DNA) é menor que a obtida para a sonda e sequência não complementar. Isso ocorre devido à formação dos pares de bases (A-T, C-G) com ligações de hidrogênio. $\mathrm{O}$ movimento de flexão de $\mathrm{NH}_{2}$ da adenina torna-se mais restrito no par de bases e, portanto, a energia do movimento 
de $\mathrm{NH}_{2}$ aumenta. A frequência de estiramento da carbonila da timina na ligação de hidrogênio no par de bases A-T diminuiu após a formação do par de bases, devido à diminuição da constante da força de C-O com a ligação de hidrogênio. As áreas sob os espectros para a sonda e sequência não complementar são próximas, o que significa não ter ocorrido hibridização da sequência não complementar.

Figura 10: Espectro de PM-IRRAS: (a) Sonda (NH2-ssDNA) imobilizada sobre MUA em ouro; (b) sequência complementar (ds-DNA) hibridizada na sonda; (c) sequência não complementar (nc-DNA).

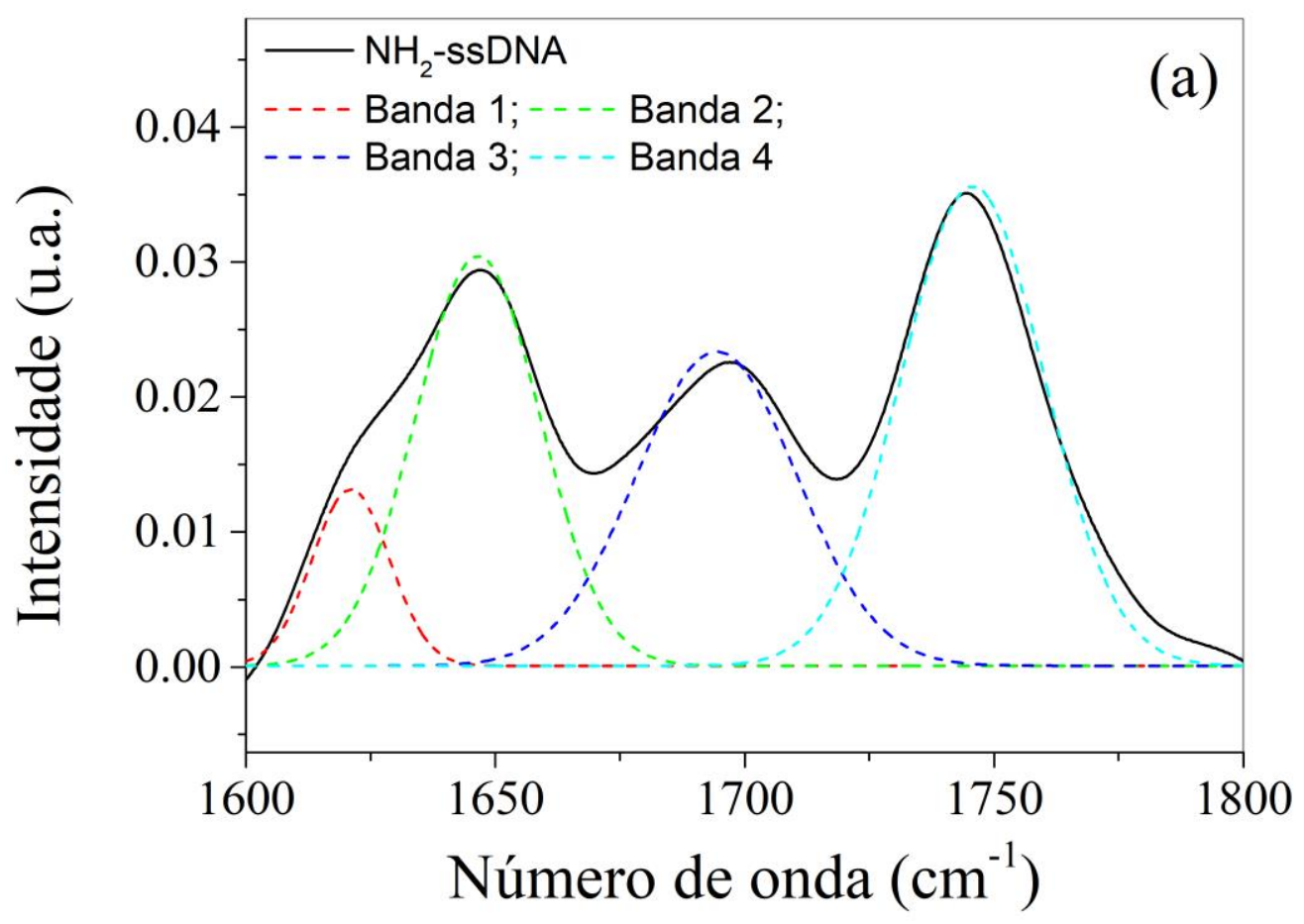

(continua) 

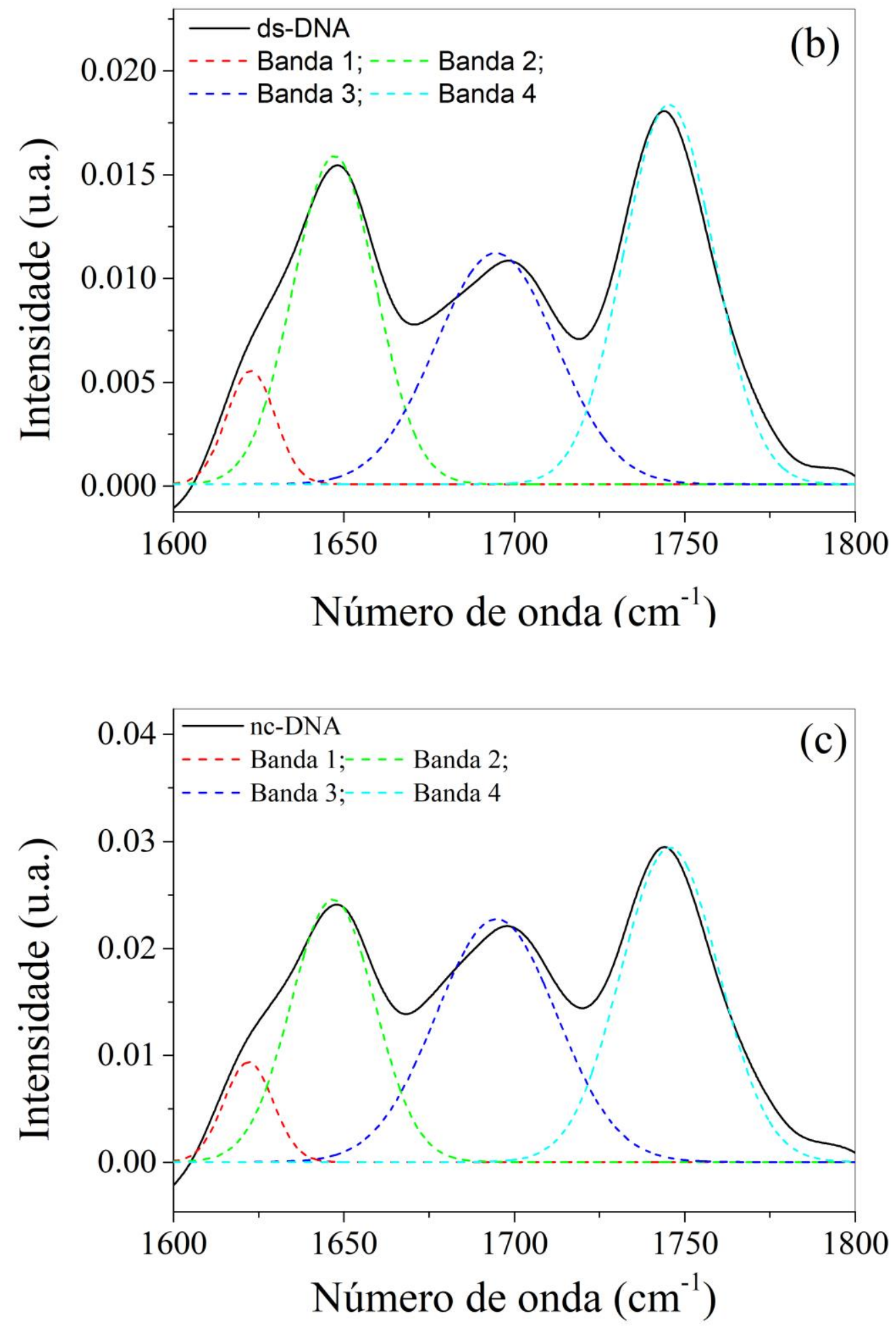

Fonte: Elaborado pela autora. 
Tabela 2: Atribuição das bandas com desconvolução dos espectros de PM-IRRAS da Figura 10.

\begin{tabular}{cc}
\hline Posição $\left(\mathbf{c m}^{-1}\right)$ & Atribuição das bandas \\
\hline 1622 & Flexão $\mathrm{NH}_{2}$ da Guanina \\
1646 & Deformação do anel (estiramento $\mathrm{C}=\mathrm{N})$ da Citosina \\
1694 & Estiramento da carbonila da Timina \\
1745 & Estiramento da carbonila da Timina \\
\hline
\end{tabular}

Fonte: Elaborado pela autora. 
Tabela 3: Parâmetros de área e largura de banda das bandas com deconvolução dos espectros de PM-IRRAS da Figura 10.

\begin{tabular}{|c|c|c|c|}
\hline Banda 1 & $\begin{array}{c}\text { W (largura da } \\
\text { banda) }\end{array}$ & A (área) & Posição $\left(\mathrm{cm}^{-1}\right)$ \\
\hline $\mathrm{NH}_{2}$-SSDNA & $18,23 \pm 3,84$ & $0,25 \pm 0,09$ & 1621 \\
\hline ds-DNA & $14,10 \pm 4,01$ & $0,09 \pm 0,04$ & 1622 \\
\hline nc-DNA & $14,40 \pm 4,20$ & $0,16 \pm 0,08$ & 1622 \\
\hline Banda 2 & $\begin{array}{c}\text { W (largura da } \\
\text { banda) }\end{array}$ & A (área) & Posição $\left(\mathrm{cm}^{-1}\right)$ \\
\hline $\mathrm{NH}_{2}$-SsDNA & $29,52 \pm 3,82$ & $0,95 \pm 0,12$ & 1646 \\
\hline ds-DNA & $24,23 \pm 3,32$ & $0,48 \pm 0,06$ & 1647 \\
\hline nc-DNA & $24,57 \pm 3,94$ & $0,75 \pm 0,12$ & 1646 \\
\hline Banda 3 & $\begin{array}{c}\text { W (largura da } \\
\text { banda) }\end{array}$ & A (área) & Posição $\left(\mathrm{cm}^{-1}\right)$ \\
\hline $\mathrm{NH}_{2}$-SSDNA & $37,88 \pm 3,88$ & $0,93 \pm 0,08$ & 1694 \\
\hline ds-DNA & $35,21 \pm 4,66$ & $0,49 \pm 0,05$ & 1694 \\
\hline nc-DNA & $35,40 \pm 4,34$ & $1,00 \pm 0,10$ & 1694 \\
\hline Banda 4 & $\begin{array}{c}\text { W(largura da } \\
\text { banda) }\end{array}$ & A (área) & Posição $\left(\mathrm{cm}^{-1}\right)$ \\
\hline $\mathrm{NH}_{2}$-ssDNA & $33,71 \pm 1,68$ & $1,27 \pm 0,07$ & 1745 \\
\hline ds-DNA & $26,67 \pm 1,52$ & $0,61 \pm 0,04$ & 1745 \\
\hline nc-DNA & $28,81 \pm 1,88$ & $1,06 \pm 0,07$ & 1745 \\
\hline
\end{tabular}

Fonte: Elaborado pela autora. 


\subsubsection{Medidas de Ângulo de Contato e Energia de superfície}

Foi medido o ângulo de contato em todas as etapas de construção do genossensor, com três solventes: água, formamida e diiodometano. Foram preparadas duas plataformas para o genossensor, uma com MAA em água ou etanol, para determinar o melhor solvente para obter um sensor eficiente. Outra plataforma estudada foi com MUA em etanol. Na Figura 11 observa-se que a monocamada automontada preparada em etanol (MAA-E) teve ângulo de contato menor que para a monocamada automontada preparada em água (MAA-H), indicando a hidrofilicidade da superfície. A estrutura do DNA é formada por um grupo fosfato e açúcar, sendo polar, enquanto sua parte interior (bases nitrogenadas $A, T$, $\mathrm{C}, \mathrm{G})$ é apolar. Assim, o ângulo de contato para sonda $\left(\mathrm{NH}_{2}\right.$-ssDNA) e para a sequência não complementar (nc-DNA) foi característico de superfícies com menor hidrofilicidade, pois as bases nitrogenadas estavam expostas na superfície (ZHANG et al., 2008). Ao contrário, para a sequência complementar (ds-DNA) apenas os grupos fosfatos estavam expostos, gerando comportamento mais hidrofílico (JAISWAL et al., 2018). 
Figura 11: Ângulos de contato do eletrodo de ouro, monocamadas automontadas (MAA) preparadas em água e etanol, sonda ( $\mathrm{NH}_{2}$-ssDNA), sequência complementar (ds-DNA) e não complementar (ncDNA). São apresentadas medidas para três líquidos: água, formamida e diiotometano.
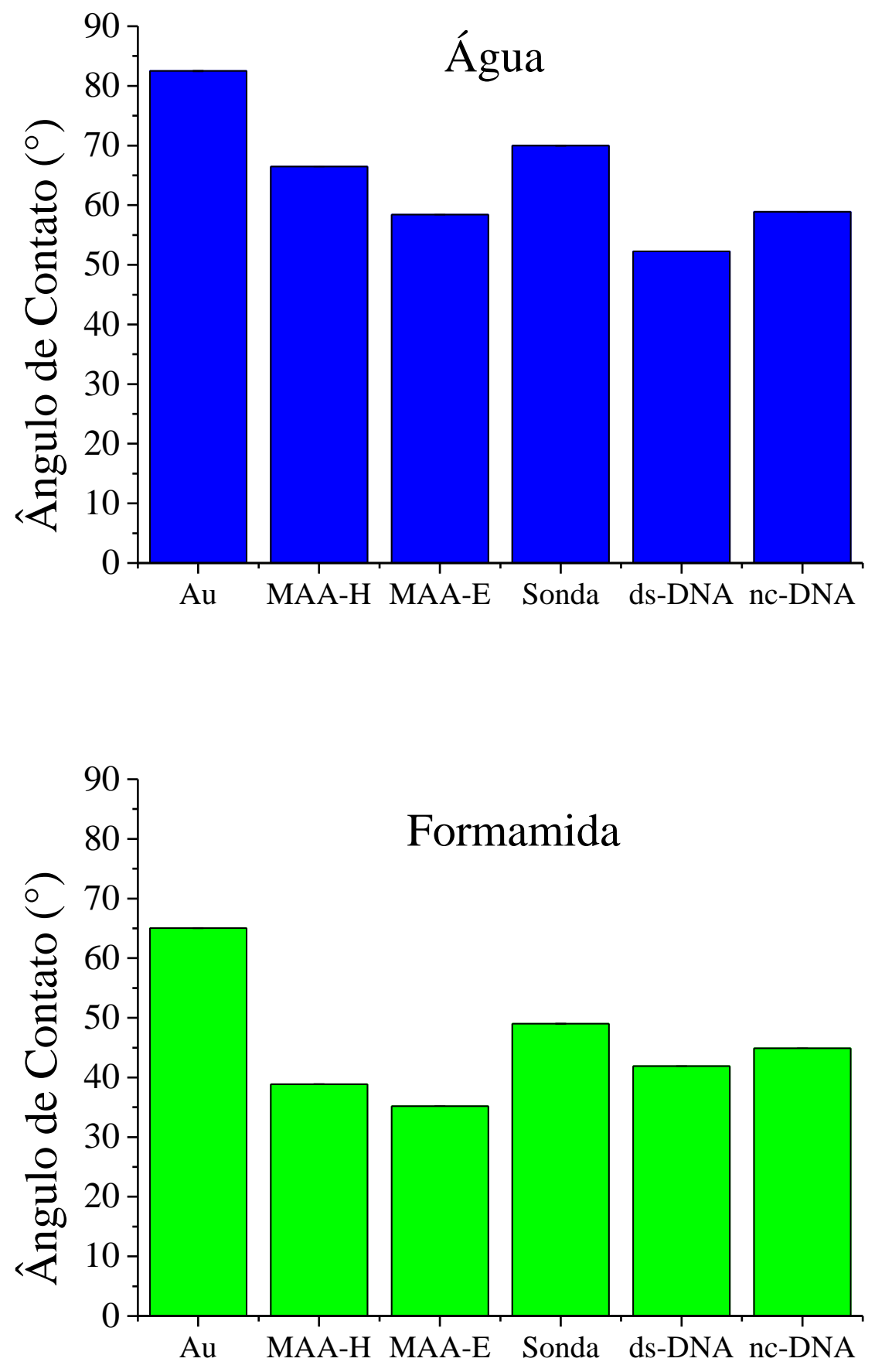

(Continua) 


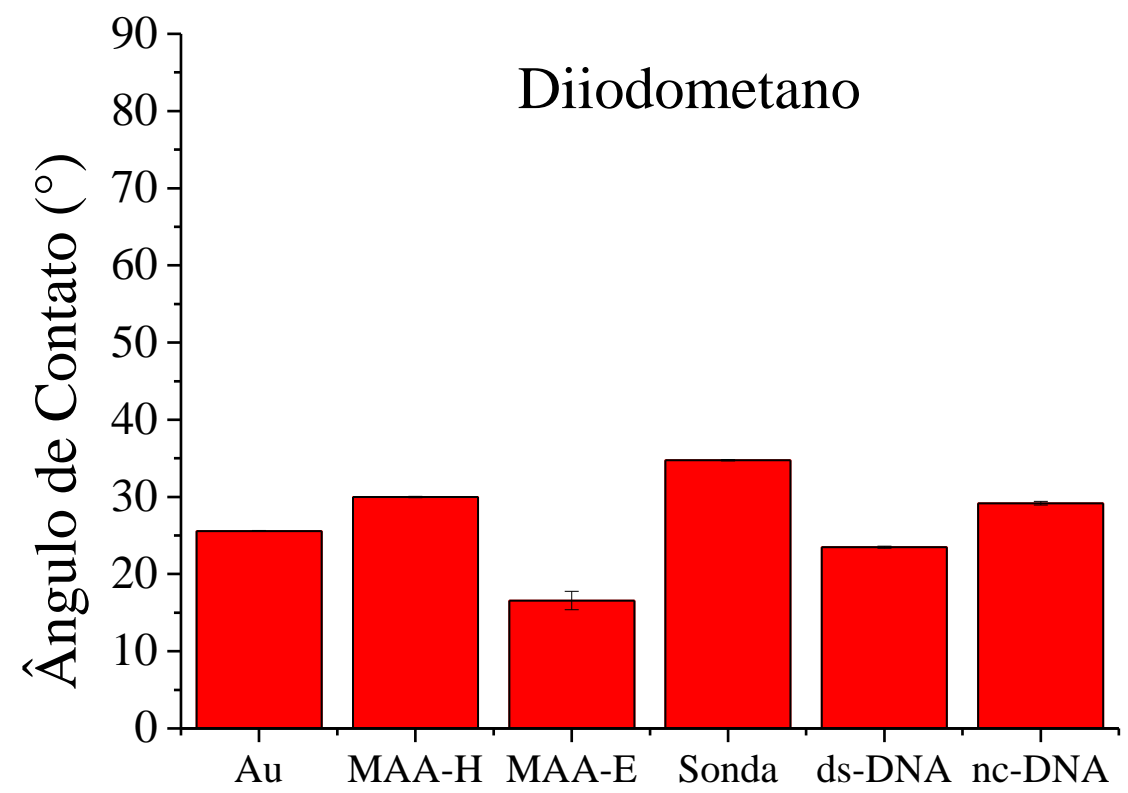

Fonte: Elaborado pela autora.

A Figura 12 mostra os ângulos de contato para a plataforma de MUA em etanol. O MUA possui uma parte polar (grupo carboxila) e outra parte apolar (cadeia carbônica). Quanto maior a parte apolar da cadeia mais insolúvel em água será, e por isso ácidos carboxílicos com mais de 10 carbonos não são solúveis em água, que é o caso do MUA com 11 carbonos. Nos filmes produzidos o MUA apresentou característica de superfície com menor hidrofilicidade, com valores elevados de ângulo de contato. A sonda ( $\mathrm{NH}_{2}$-ssDNA), como já citado, é apolar devido às bases nitrogenadas estarem expostas, apresentando característica hidrofóbica e o ângulo de contato menor que para o MUA. 
Figura 12: Ângulos de contato do eletrodo de ouro, monocamadas automontadas (MUA) preparadas em etanol, sonda ( $\mathrm{NH}_{2}$-ssDNA), etanolamina (Et-OH), sequência complementar (ds-DNA) e não complementar (nc-DNA). Medidas para os líquidos: água, formamida e diiodometano.
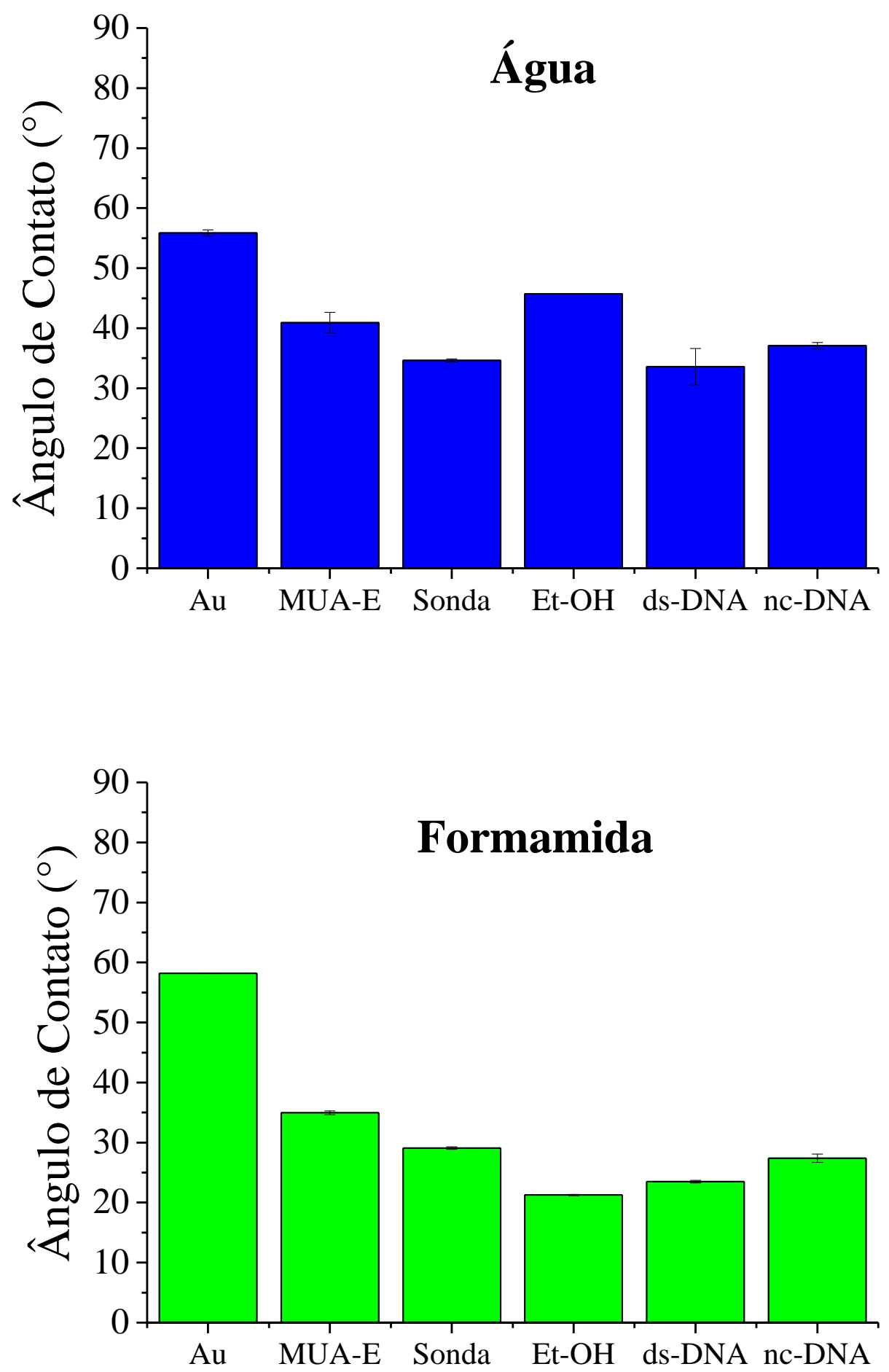

(Continua) 


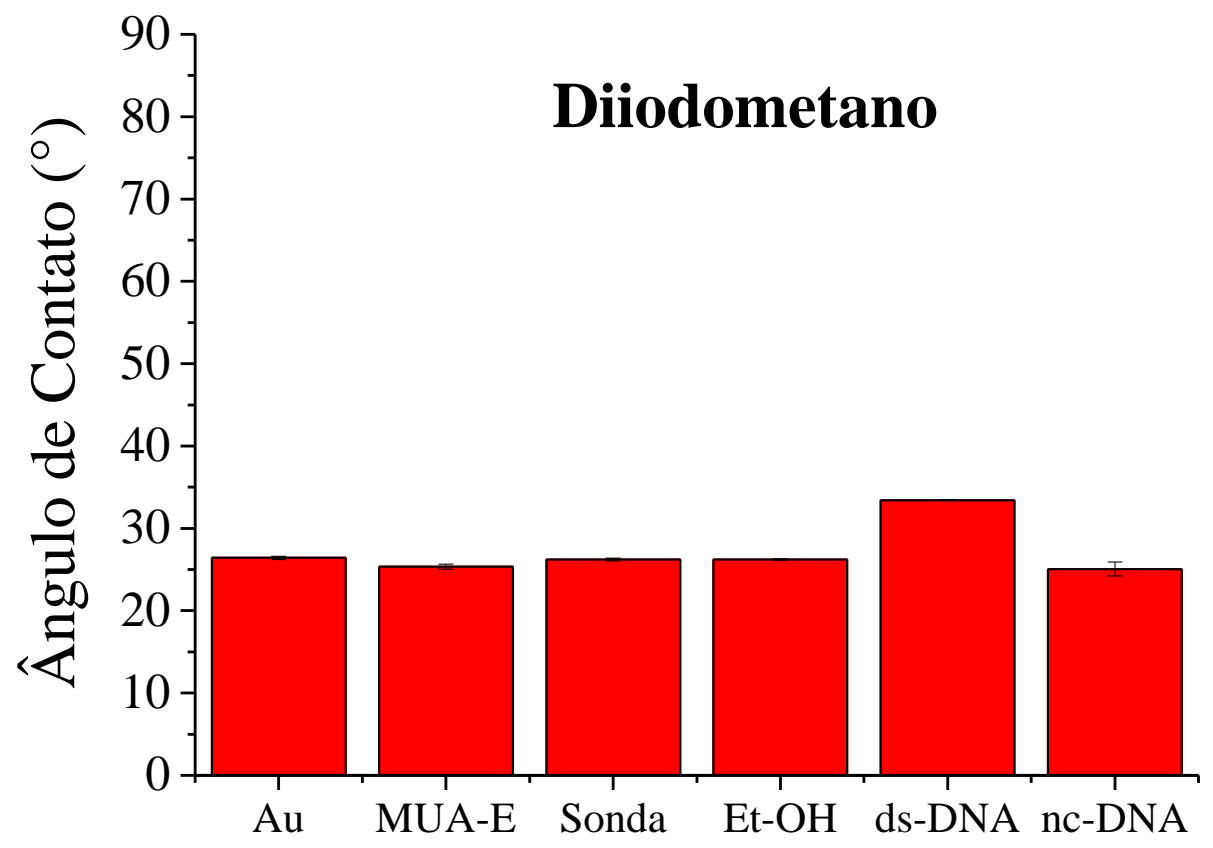

Fonte: Elaborado pela autora.

A energia de superfície é definida como aumento da energia livre do sistema por unidade de área superficial criada, ou seja, é o trabalho reversível requerido para aumentar a superfície por unidade de área. Esse é o trabalho de adesão, relacionado com a interação entre as superfícies em contato. Quanto maior a energia de superfície maior será a adesão. Na Figura 13 é mostrada a energia de superfície, calculada segundo o modelo de Owens-Wendt-Rabel-Kaelble (OWENS; WENDT, 1969), para diferentes modificações no eletrodo de ouro. Foram preparados eletrodos com monocamada automontada (MAA) em água e etanol, eletrodo contendo MAA/NH ${ }_{2}$-ssDNA, MAA/NH ${ }_{2}$-ssDNA/ds-DNA (sequência complementar) e $\mathrm{MAA} / \mathrm{NH}_{2}$-ssDNA/nc-DNA (sequência não complementar). A energia de superfície da monocamada automontada (MAA) preparada em etanol foi maior que MAA preparada em água. Isso significa que a MAA em etanol melhora a adesão superficial e a imobilização da sonda $\left(\mathrm{NH}_{2}-\mathrm{DNA}\right)$, que seria o passo seguinte para a construção do genossensor. 
Figura 13: Gráficos de energia de superfície do eletrodo de ouro, monocamadas automontadas (SAM) de MAA preparadas em água e etanol, sonda $\left(\mathrm{NH}_{2}\right.$-SSDNA), sequência complementar (dsDNA) e não complementar (nc-DNA).

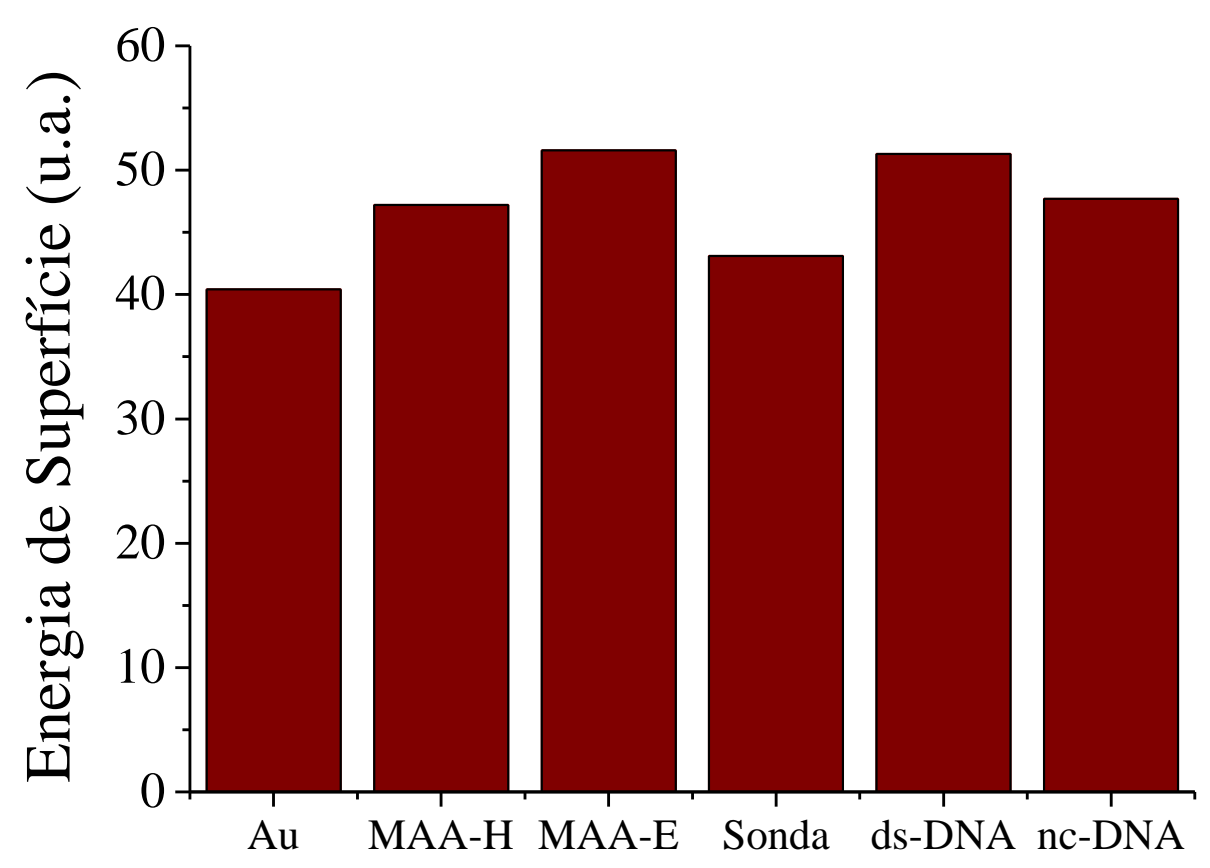

Fonte: Elaborado pela autora.

Na Figura 14a energia de superfície para a sonda e sequência complementar foi maior que para outras moléculas, o que significa que as moléculas tiveram maior adesão, consequentemente, melhor imobilização em comparação com a monocamada automontada de MAA em etanol. 
Figura 14: Gráficos de energia de superfície do eletrodo de ouro, monocamadas automontadas (SAM) de MUA preparada em etanol, sonda $\left(\mathrm{NH}_{2}-\mathrm{SsDNA}\right)$, etanolamina (Et-OH), sequência complementar (ds-DNA) e não complementar (nc-DNA).

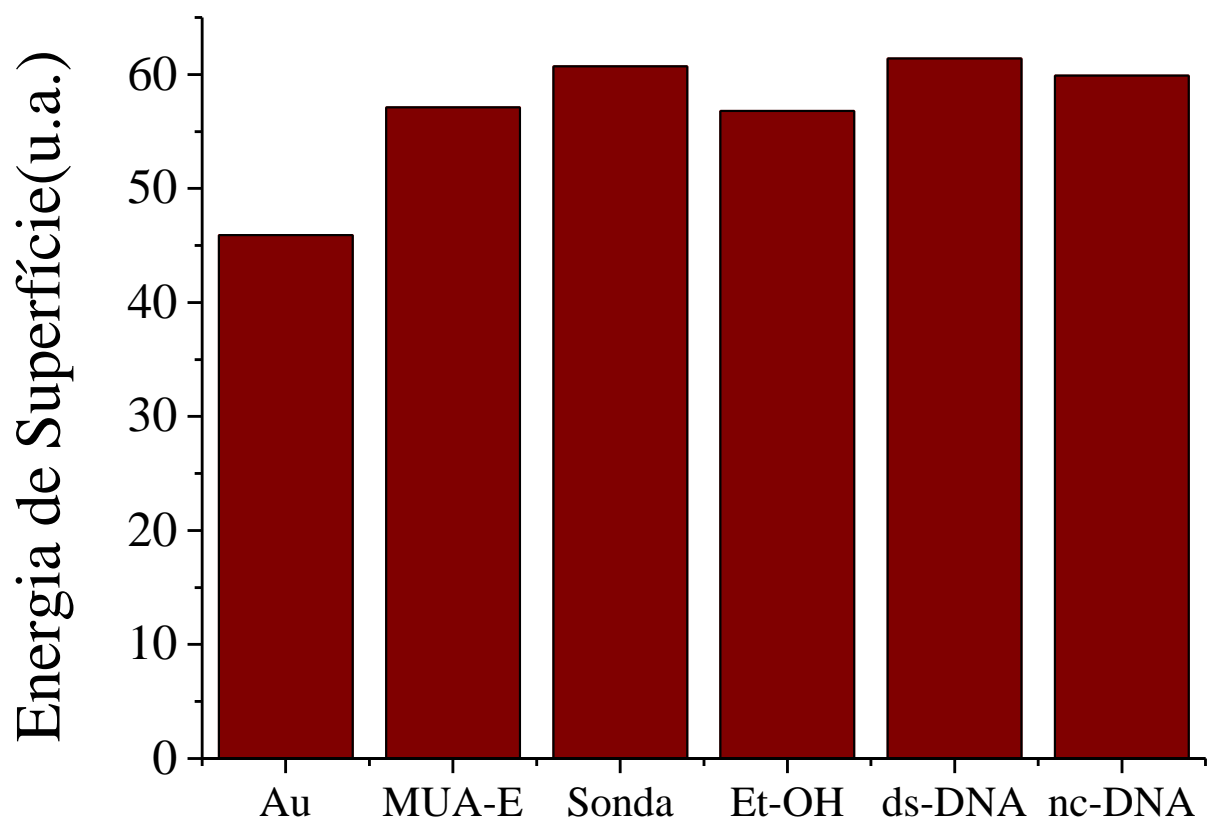

Fonte: Elaborada pela autora.

\subsection{Otimização do Genossensor com MAA}

\subsubsection{Influência do solvente na SAM (MAA)}

Num estudo preliminar para identificar a arquitetura otimizada para sensoriamento, foram realizadas medidas de espectroscopia de impedância para genossensores formados com SAMs obtidas com água e etanol. Como será discutido na próxima seção, nessas medidas subtraímos a resistência à transferência de carga $\left(R_{c t}\right)$ obtida com o genossensor contendo a sonda da medida com o analito. A Figura 15a mostra que a diferença de Rct aumenta com a concentração do analito, que é a sequência complementar a sonda de DNA, indicadora de câncer. A reta para a SAM preparada em etanol tem inclinação maior, indicando maior sensibilidade devido à organização da SAM sobre o ouro. Para o 
etanol a reta pode ser descrita pela equação $\Delta R_{c t} / R_{c t}(s s D N A)=180,76+12,27 \log C$, onde $C$ é a concentração em mol/L, tendo como limite de detecção $2,9 \times 10^{-15} \mathrm{M}$. Para a água usada como solvente a equação que descreve ao ajuste é $\Delta R_{\mathrm{ct}} / R_{\mathrm{ct}}$ $($ ssDNA $)=129,78+8,88 \log \mathrm{C}$, com limite de detecção $1,6 \times 10^{-14} \mathrm{M}$, ambos estimados pelo cálculo $L O D=a+3 S D$, sendo ao coeficiente linear e SD o desvio padrão da regressão linear (MILLER; MILLER, 1988). Estes resultados estão de acordo com os obtidos por PM-IRRAS, mostrados na Figura 15b, pois o sinal obtido para SAM em etanol é maior que em água, mostrando que há maior quantidade de moléculas de MAA. O destaque é para a banda em $1700 \mathrm{~cm}^{-1}$ referente ao grupo $\mathrm{COOH}$. A maior intensidade para a SAM em etanol sugere mais grupos carboxilas expostos na superfície, o que proporcionaria maior eficiência na imobilização. A banda $v(C=0)$ de $1700 \mathrm{~cm}^{-1}$ indica a ligação de hidrogênio intermolecular dos grupos de cauda de ácido carboxílico. A banda em $1728 \mathrm{~cm}^{-1}$ é devida ao metileno $\left(\mathrm{CH}_{2}\right)$ (DUTRA; SOARES, 1998). A presença das bandas $\mathrm{v}_{\text {as }}\left(\mathrm{CO}_{2}{ }^{-}\right) \mathrm{em} 1660 \mathrm{~cm}^{-1} \mathrm{e}$ $v_{\mathrm{s}}\left(\mathrm{CO}_{2}{ }^{-}\right)$em $1624 \mathrm{~cm}^{-1}$ indica que parte da molécula de ácido é ionizada na formação da monocamada (CHUNG; LEE, 2004). 
Figura 15: a) Resistência à transferência de carga $\left(\mathrm{R}_{\mathrm{ct}}\right)$ da sonda $\left(\mathrm{NH}_{2}\right.$-ssDNA) e da sequência complementar (ds-DNA) para SAM preparada em água e etanol obtida das medidas eletroquímicas;

b) espectro de PM-IRRAS apenas do eletrodo modificado com SAM em água e etanol
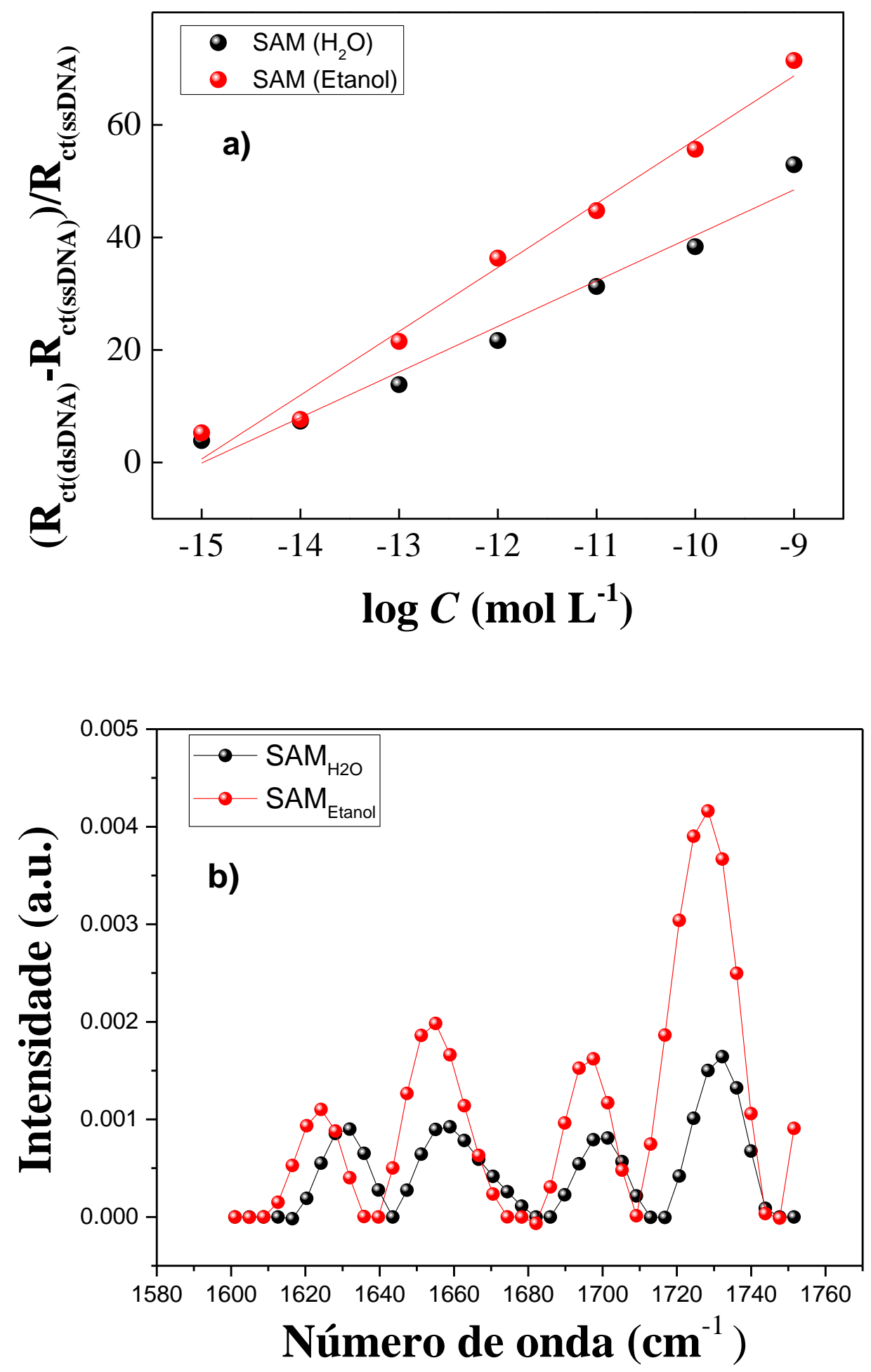

Fonte: Elaborado pela autora. 


\subsubsection{Tentativas Frustradas de Obter Seletividade com Genossensores}

Os experimentos para caracterizar os filmes que compõem os genossensores acima foram complementados com alguns que mostraram ser possível identificar mudanças nas propriedades do genossensor oriundas de interação com a sequência complementar (ds-DNA), típica de hibridização. Gerou-se a expectativa, assim, de que genossensores produzidos com a arquitetura molecular escolhida pudessem ser seletivos e sensíveis. Para confirmar essa expectativa foram realizados experimentos com sequências complementares e não complementares, a diferentes concentrações. O primeiro passo, porém, foi de otimizar os parâmetros de fabricação dos genossensores, tomando como meta obter a máxima variação da impedância eletroquímica quando é alterada a concentração da sequência complementar. Esta seção traz uma série de resultados da otimização e de medidas com os genossensores. Como será mostrado, muitas tentativas foram frustrantes, pois não se observou seletividade. Para o leitor interessado apenas nos resultados positivos de sensoriamento, recomenda-se passar para a subseção 4.3 , em que são mostrados os resultados de genossensores otimizados.

\subsubsection{Otimização dos Parâmetros de Produção do Genossensor}

Foram considerados os parâmetros temperatura e tempo de hibridização das sequências complementar (ds-DNA) e não complementar (nc-DNA), usando como método de detecção a impedância eletroquímica. Essas medidas foram realizadas em $5 \mathrm{mM}$ de ferrocianeto e ferricianeto de potássio $\left(\mathrm{K}_{3}\left[\mathrm{Fe}(\mathrm{CN})_{6}\right] / \mathrm{K}_{4}\left[\mathrm{Fe}(\mathrm{CN})_{6}\right]\right)$ em PBS/ $\mathrm{MgCl}_{2}(1 \mathrm{mM})$. Os eletrodos foram preparados com MAA em etanol (50 mM). A Figura 16 mostra espectros de impedância do genossensor preparado com MAA e a sonda $\left(\mathrm{NH}_{2}\right.$-ssDNA) $1 \mu \mathrm{M}$ em PBS/MgCl 2 (1 mM). Foram utilizadas diferentes temperaturas $\left(25^{\circ} \mathrm{C}\right.$ a $80^{\circ} \mathrm{C}$ ) de hibridização para a sequência complementar (dsDNA) em concentração de $10^{-8} \mathrm{M}$. O tempo de exposição para cada temperatura foi de $30 \mathrm{~min}$, sendo que eram deixados mais $30 \mathrm{~min}$ para esfriar depois. Nota-se na Figura 16 que o espectro da impedância da sequência ds-DNA começou a se 
distinguir do espectro da sonda a partir de $45^{\circ} \mathrm{C}$, com a impedância aumentando com a temperatura até $80^{\circ} \mathrm{C}$.

Figura 16: Espectro de impedância do genossensor construído a partir da monocamada automontada de MAA em etanol, sonda ( $\mathrm{NH}_{2}$-ssDNA) e sequência complementar (ds-DNA) $\left(10^{-8} \mathrm{M}\right)$ com diferentes temperaturas de hibridização: $25,35,45,60$ e $80^{\circ} \mathrm{C}$.

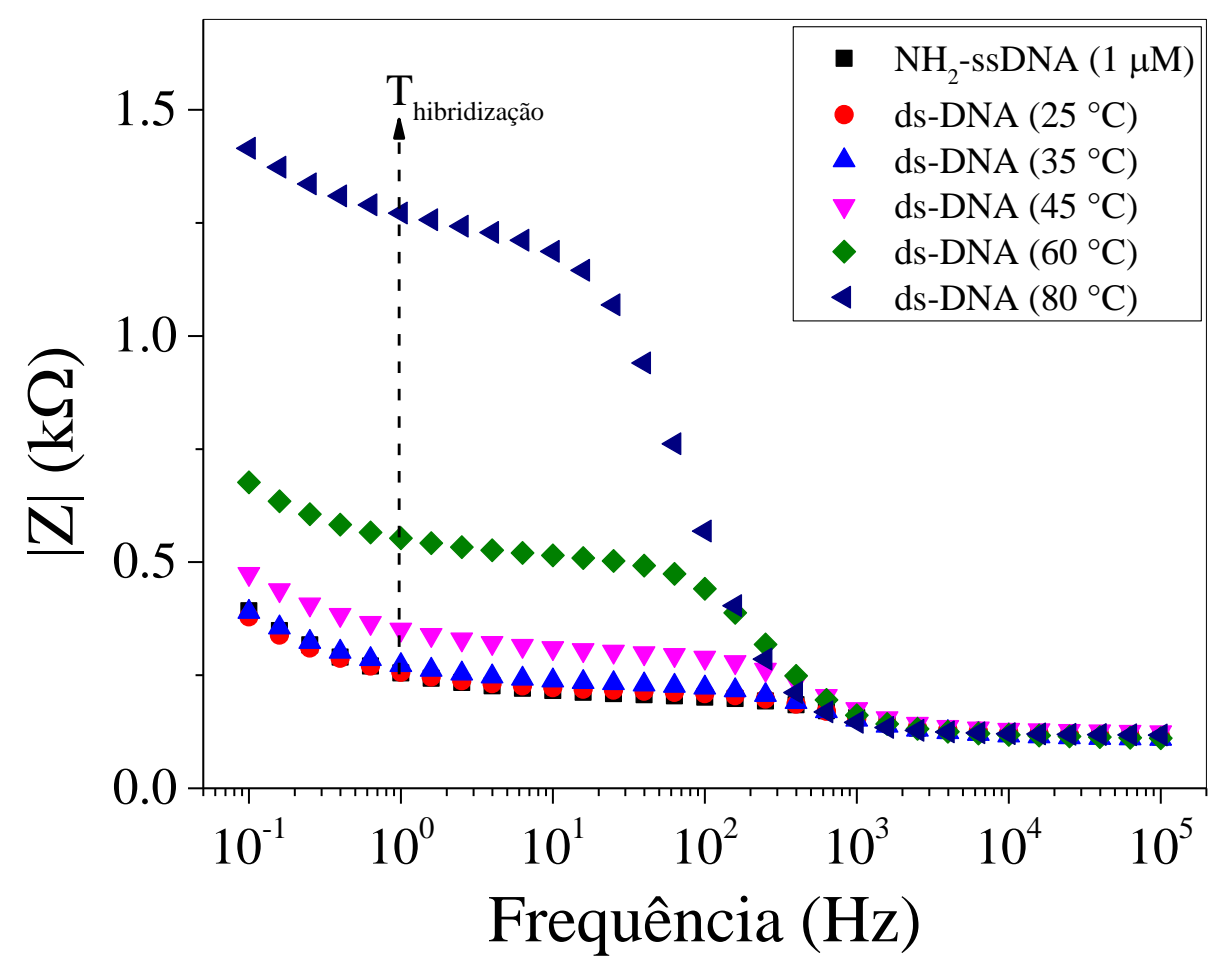

Fonte: Elaborado pela autora.

A Figura 17 mostra a diferença do sinal da sequência complementar (dsDNA) em diferentes temperaturas de hibridização menos o sinal da sonda $\left(\mathrm{NH}_{2}{ }^{-}\right.$ ssDNA) em $1 \mathrm{~Hz}$. A variação na impedância aumenta com a temperatura, indicando que - das temperaturas testadas - a de $80{ }^{\circ} \mathrm{C}$ leva a resultados com melhor distinção entre a sonda (fita simples) e a sequência complementar (ds-DNA) hibridizada (dupla hélice). Não foram usadas temperaturas maiores do que $80{ }^{\circ} \mathrm{C}$, pois o grande tempo de exposição em altas temperaturas poderia degradar a sequência de DNA. Da literatura infere-se que a temperatura de hibridização usada em genossensores é de $40{ }^{\circ} \mathrm{C}$ a $50{ }^{\circ} \mathrm{C}$ (WANG; SAURIAT-DORIZON; KORRIYOUSSOUFI, 2017). 
Figura 17: Diferença do sinal $\left(|Z|-\left|Z_{0}\right|\right)(1 \mathrm{~Hz})$ em função da temperatura de hibridização para a sequência complementar (ds-DNA) $\left(10^{-8} \mathrm{M}\right)$.

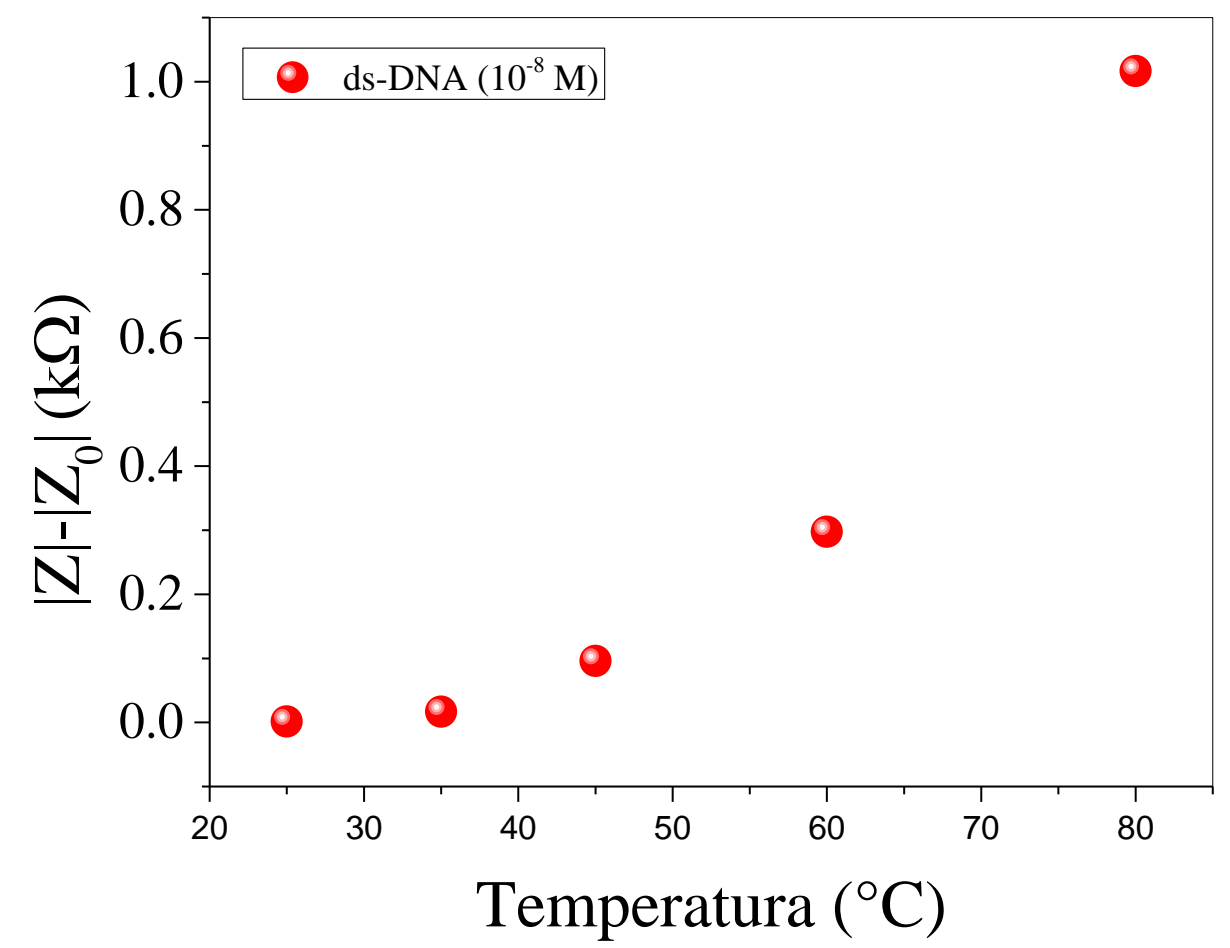

Fonte: Elaborado pela autora.

Dos resultados anteriores foram determinados os parâmetros para obter um desempenho otimizado para os genossensores. Para as medidas com diferentes concentrações de analito, foram preparados, portanto, genossensores com os seguintes parâmetros:

i) matriz obtida com monocamada SAM de MAA obtida com $50 \mathrm{mM}$ em etanol com tempo de adsorção de 1 dia.

ii) tempo de deposição da sonda $\left(\mathrm{NH}_{2}\right.$-ssDNA) de $2 \mathrm{~h}$. em $1 \mu \mathrm{M}$ em $\mathrm{PBS} / \mathrm{MgCl}_{2}(1 \mathrm{mM})$.

iii) temperatura de $80^{\circ} \mathrm{C}$ para os experimentos de detecção, com tempo de exposição para hibridização de 30 min.

Os espectros de impedância para diferentes concentrações da sequência complementar (ds-DNA) são mostrados na Figura 18, em que se observa claro 
deslocamento do espectro para maiores impedâncias com o aumento da concentração de ds-DNA. Isso significa que o genossensor está diferenciando a sequência hibridizada (dupla fita) da sonda (fita simples).

Figura 18: Espectros de impedância do genossensor construído com a monocamada automontada de MAA em etanol, sonda ( $\mathrm{NH}_{2}$-SSDNA) e sequência complementar (ds-DNA), para várias concentrações $\left(10^{-9}\right.$ a $\left.10^{-6} \mathrm{M}\right)$. Temperatura de hibridização fixa em $80^{\circ} \mathrm{C}$.

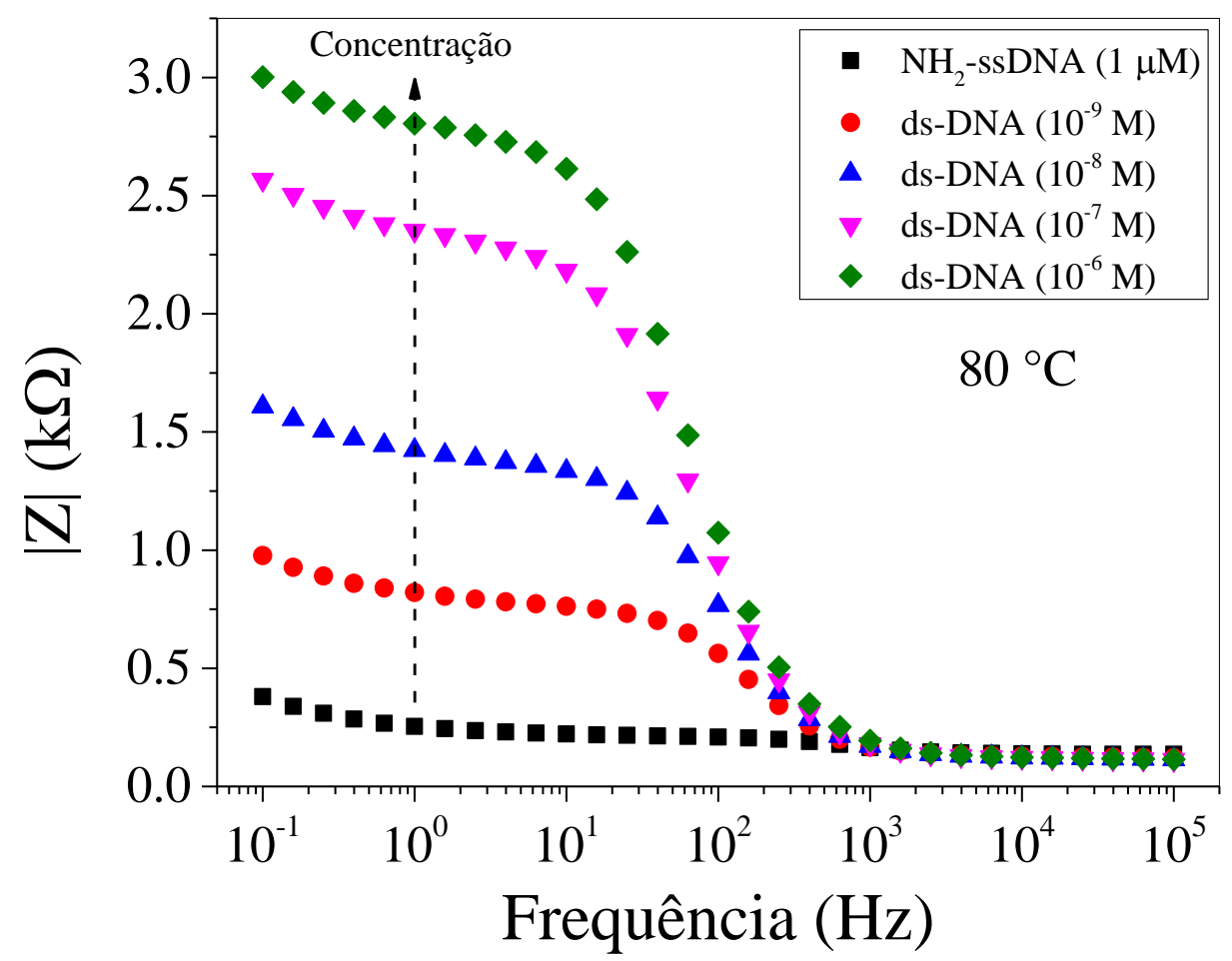

Fonte: Elaborado pela autora.

Com o mesmo procedimento foram obtidos espectros para genossensores expostos a diferentes concentrações da sequência não complementar (nc-DNA). Como mostra a Figura 19, o resultado não foi o esperado, pois os espectros também dependeram da concentração. Ou seja, houve diferenciação da sequência não complementar, assim como havia sido observado com a sequência complementar. 
Figura 19: Espectros de impedância do genossensor construído a partir da monocamada automontada de MAA em etanol, sonda ( $\mathrm{NH}_{2}$-ssDNA) e sequência não complementar (nc-DNA) variando a concentração $\left(10^{-9}\right.$ a $\left.10^{-6} \mathrm{M}\right)$. A temperatura em que os experimentos de detecção foram realizados era de $80^{\circ} \mathrm{C}$.

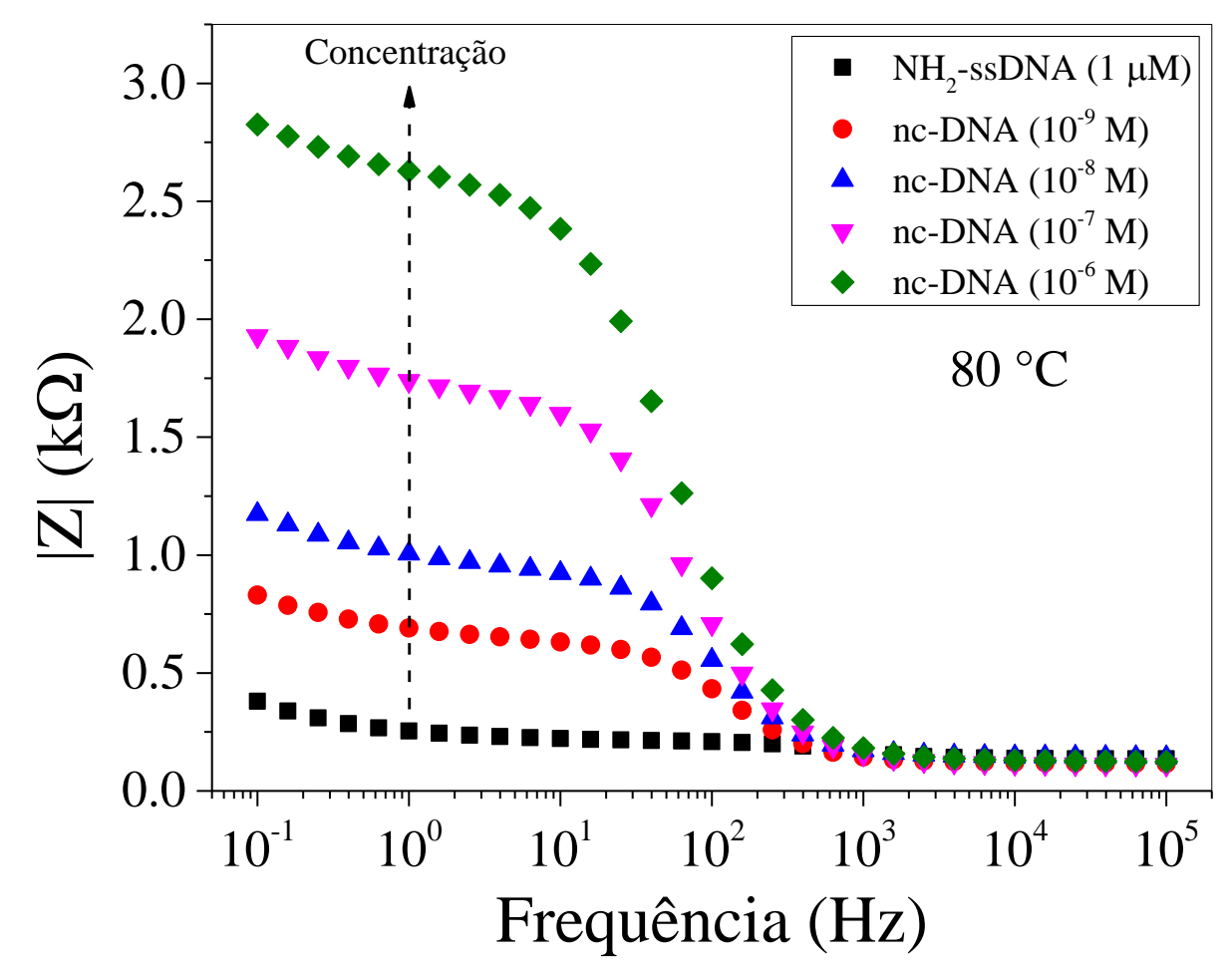

Fonte: Elaborado pela autora.

O insucesso nas medidas de sensoriamento pode ser visto numa comparação dos dados de impedância na frequência de $1 \mathrm{~Hz}$, extraídos das Figura 18 e Figura 19. Como mostra a Figura 20, a diferença de impedância entre a sequência complementar (ds-DNA) e a sonda ( $\mathrm{NH}_{2}$-ssDNA) em $1 \mathrm{~Hz}$ aumenta com a concentração praticamente da mesma forma do que se observa para a sequência não complementar (nc-DNA). Em suma, não houve seletividade nesse genossensor, pois a sequência não complementar apresentou aumento na impedância, o que não era esperado. 
Figura 20: Diferença do sinal ( $\left.|Z|-\left|Z_{0}\right|\right)$ em $1 \mathrm{~Hz}$ em função do logaritmo da concentração da sequência complementar (ds-DNA) e não complementar (nc-DNA). Temperatura em que as medidas foram realizadas: $80^{\circ} \mathrm{C}$.

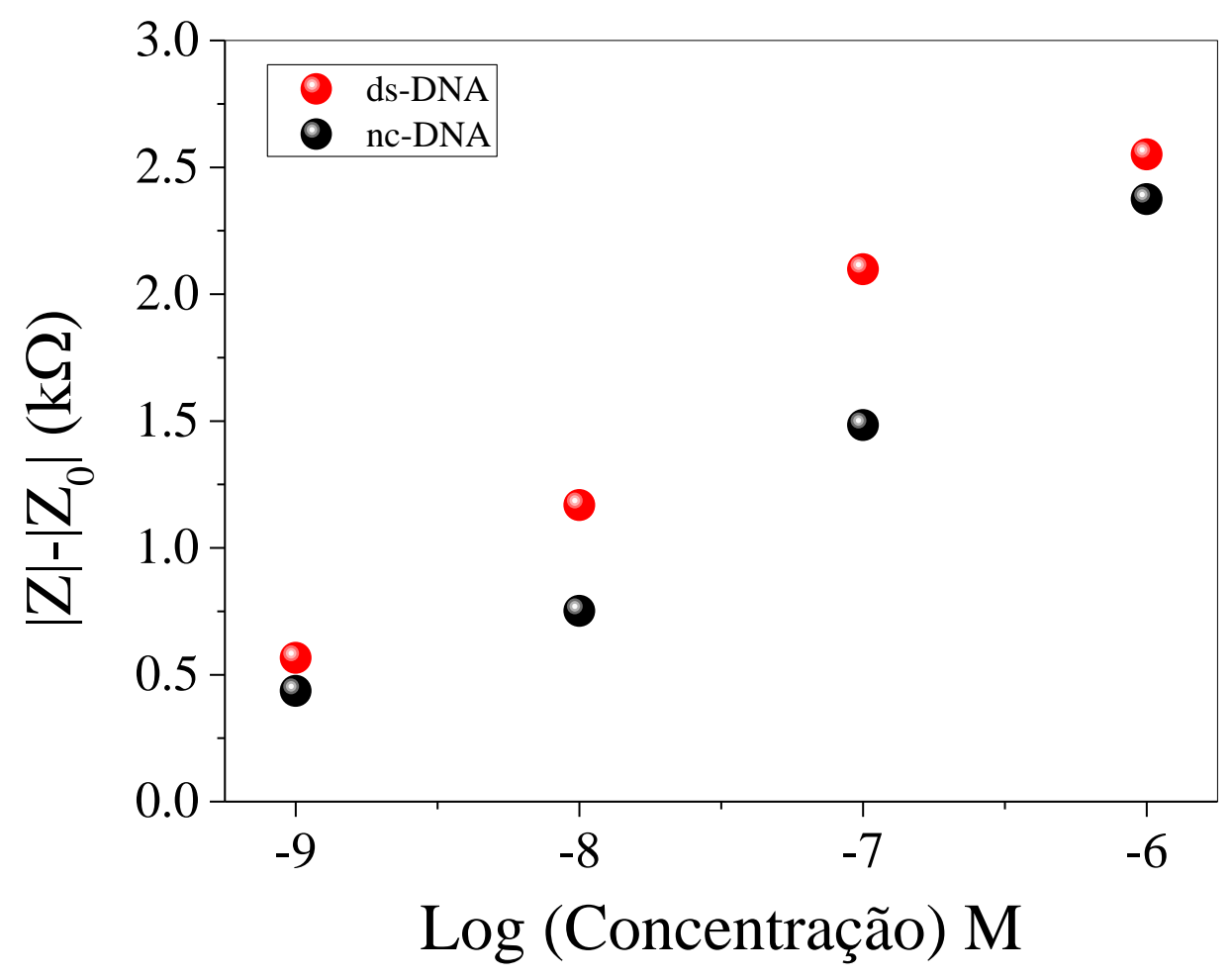

Fonte: Elaborado pela autora.

Foi realizado outro experimento em que se variou o tempo de hibridização com temperatura fixa em $80^{\circ} \mathrm{C}$, para o genossensor preparado com MAA (50 mM em etanol) e a sonda $\left(\mathrm{NH}_{2}\right.$-ssDNA) $1 \mu \mathrm{M}$ em PBS/ $\mathrm{MgCl}_{2}(1 \mathrm{mM})$. A Figura 21 apresenta os espectros da sonda e da sequência complementar (ds-DNA) com a concentração de $10^{-8} \mathrm{M}$, variando-se o tempo de exposição de $5 \mathrm{~min}$ a $60 \mathrm{~min}$. Em seguida, com o genossensor ainda imerso na solução contendo DNA, esperou-se esfriar por $30 \mathrm{~min}$ em temperatura ambiente. Este experimento mostrou que não há mudança significativa nos espectros para 5, 10, 20 e 60 min, em comparação com o espectro da sonda. Ou seja, esses tempos não foram suficientes para que ocorresse a hibridização. O tempo que apresentou melhor distinção dos espectros foi o de 30 min, nesse caso o tempo total do contato da sonda com a sequência complementar foi de $1 \mathrm{~h}$ ( $30 \mathrm{~min}$ a $80^{\circ} \mathrm{C}$ e $30 \mathrm{~min}$ em temperatura ambiente). 
Figura 21: Espectros de impedância do genossensor contendo monocamada automontada de MAA em etanol, sonda ( $\mathrm{NH}_{2}$-ssDNA) e sequência complementar (ds-DNA) variando a tempo de exposição (5 a $60 \mathrm{~min}$ ) com a temperatura de $80^{\circ} \mathrm{C}$.

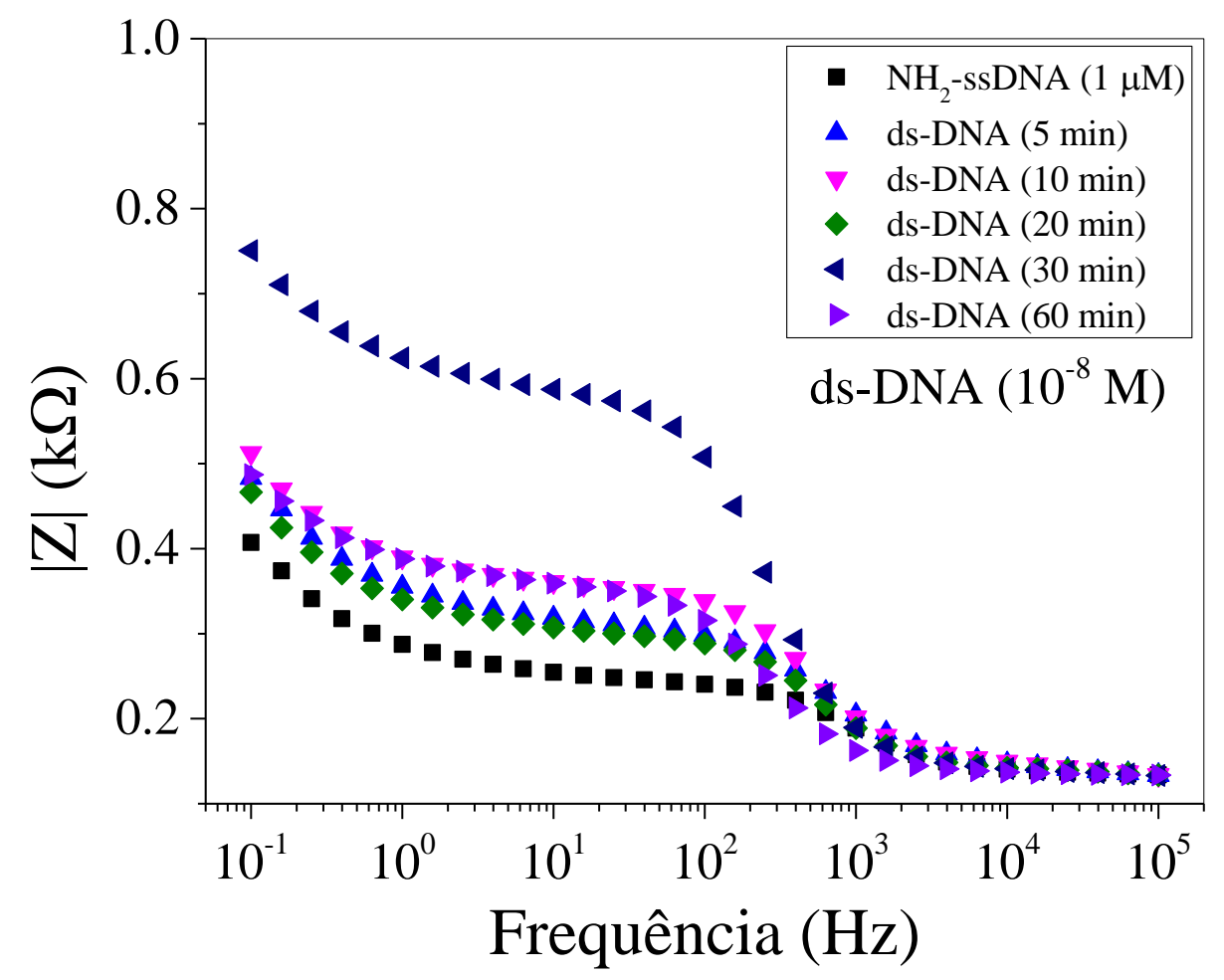

Fonte: Elaborado pela autora.

A Figura 22 apresenta a diferença do sinal da sequência complementar (dsDNA) $\left(10^{-8} \mathrm{M}\right)$ menos o sinal da sonda ( $\mathrm{NH}_{2}$-ssDNA) em função do tempo de exposição à temperatura de $80^{\circ} \mathrm{C}$. A alteração na impedância para os tempos de 5 , 10, 20 e 60 min foi no máximo de $0,103 \mathrm{k} \Omega$, enquanto para $30 \mathrm{~min}$. a impedância tem um aumento de cerca de $0,340 \mathrm{k} \Omega$, ou seja, o sinal praticamente triplicou, mostrando melhor distinção entre as sequências (fita simples e fita dupla). 
Figura 22: Diferença do sinal $\left(|Z|-\left|Z_{0}\right|\right)(1 \mathrm{~Hz})$ em função tempo de exposição a $80^{\circ} \mathrm{C}$, da sequência complementar (ds-DNA) com concentração de $10^{-8} \mathrm{M}$.

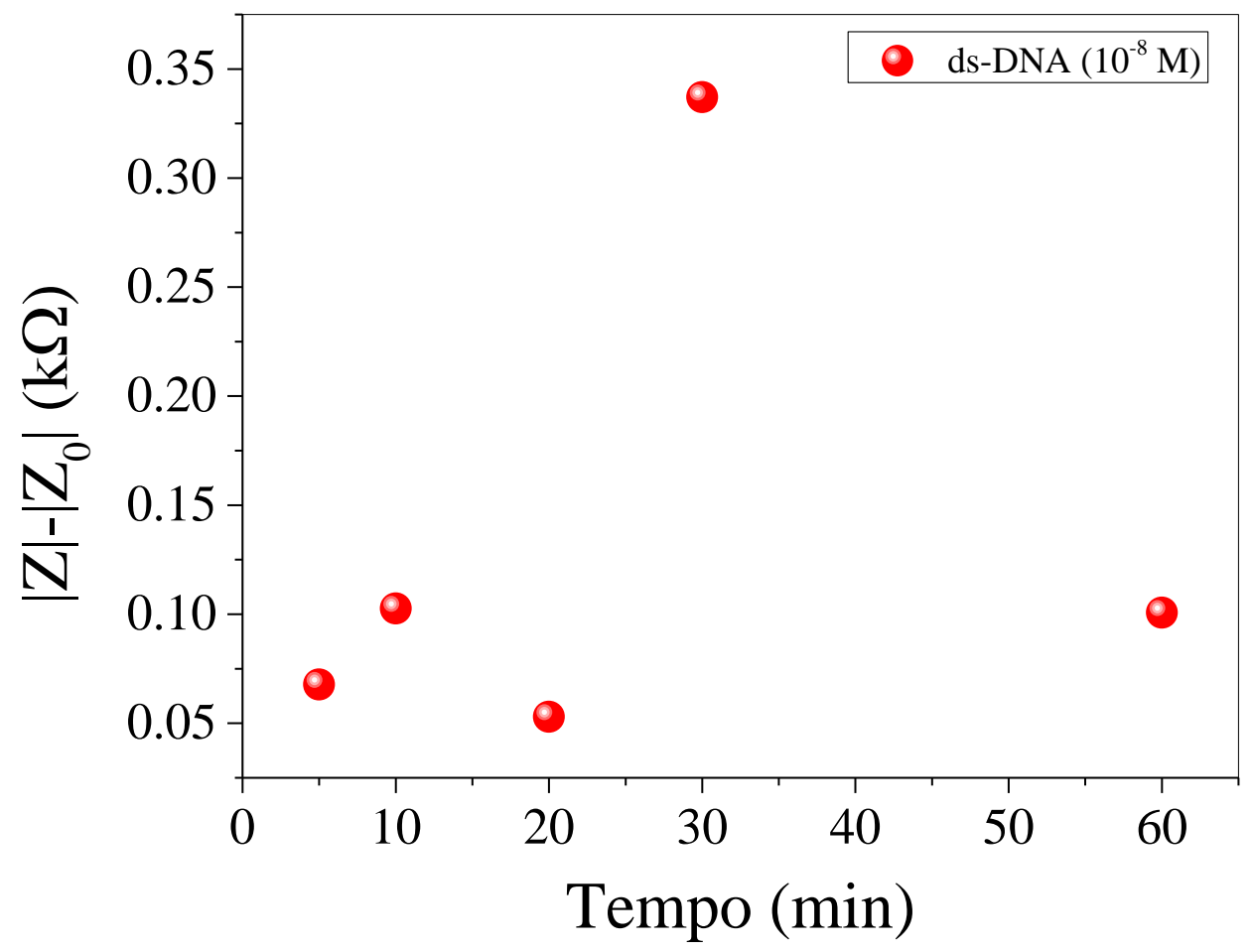

Fonte: Elaborado pela autora.

Para melhorar a seletividade do genossensor, foi usada a etanolamina como bloqueador de possíveis sítios ativos e como espaçador para a sonda $\left(\mathrm{NH}_{2}\right.$-SSDNA). O genossensor foi preparado com os mesmos parâmetros dos experimentos anteriores, MAA (50 mM em etanol), sonda ( $\mathrm{NH}_{2}$-ssDNA) $1 \mu \mathrm{M}$ em $\mathrm{PBS} / \mathrm{MgCl}_{2}$ (1 $\mathrm{mM})$. A etanolamina foi preparada em água ultrapura com $1 \mathrm{mM}$ por 1 hora de imobilização. Neste experimento variou-se a temperatura de hibridização de $25^{\circ} \mathrm{C}$ a $60{ }^{\circ} \mathrm{C}$, para a sequências complementar (ds-DNA) e não complementar (nc-DNA) ambos com $10^{-8} \mathrm{M}$. A Figura 23a mostra aumento de sinal com o aumento da temperatura de hibridização, indicando melhor distinção das sequências $\left(\mathrm{NH}_{2}\right.$ ssDNA e ds-DNA). Na Figura 23b estão os espectros da sequência não complementar (nc-DNA) para diferentes temperaturas, onde se pode notar que a distinção das sequências não é tão clara como na Figura 23a. Ainda assim, mesmo sem ligações específicas da sonda, a impedância variou com relação à referência, que é o espectro para o genossensor com etanolamina e concentração nula da sequência. 
Figura 23: Espectros de impedância do genossensor construído a partir da monocamada automontada de MAA em etanol, sonda $\left(\mathrm{NH}_{2}\right.$-SSDNA) e etanolamina, com diferentes temperaturas de hibridização: $25,35,40,60^{\circ} \mathrm{C}$. Em (a) sequência complementar (ds-DNA) $\left(10^{-8} \mathrm{M}\right)$ e (b) sequência não complementar (nc-DNA) $\left(10^{-8} \mathrm{M}\right)$.
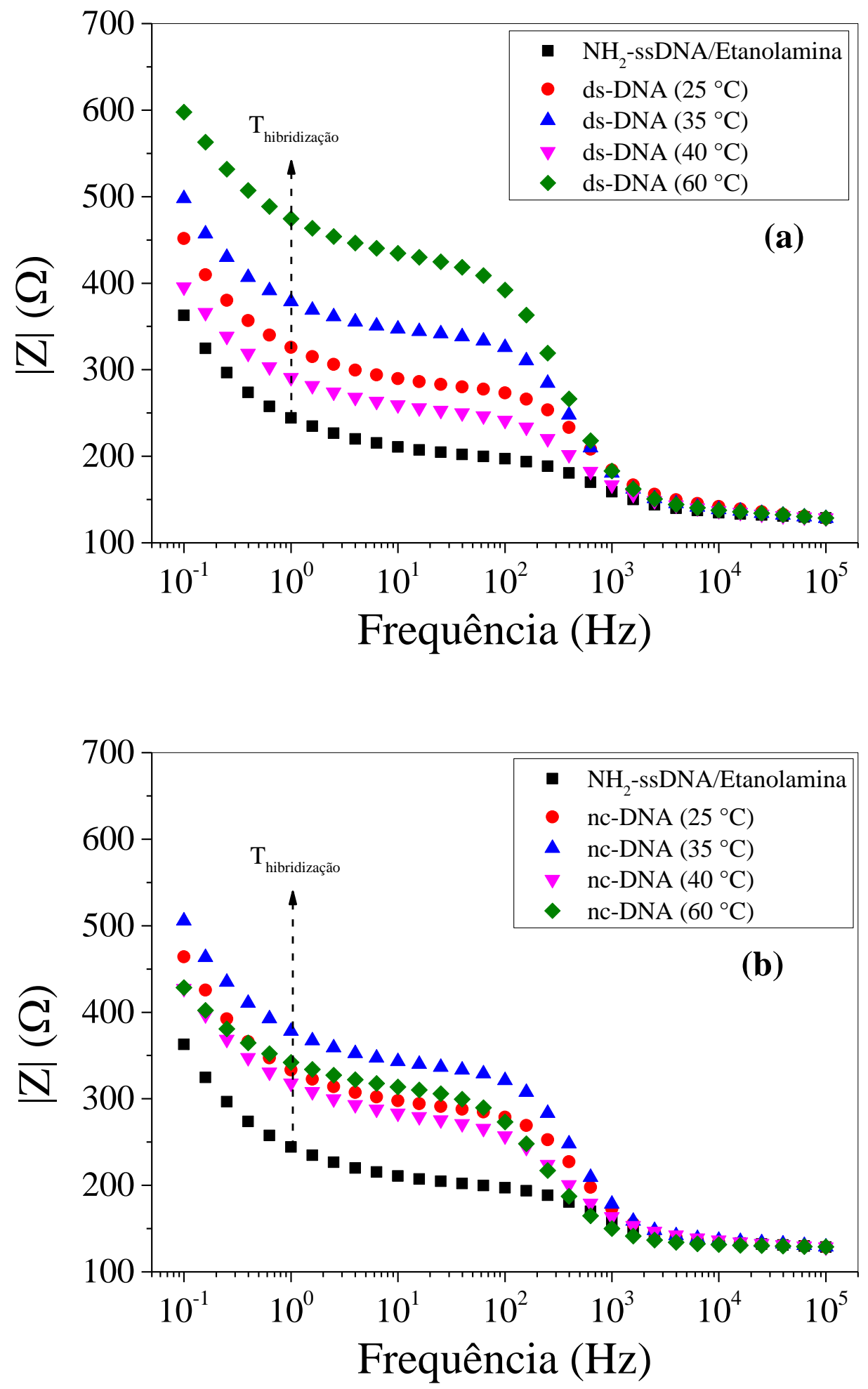

Fonte: Elaborado pela autora. 
A Figura 24 mostra a alteração na impedância das sequências analisadas (|Z|) e da sonda/Etanolamina $\left(\left|Z_{0}\right|\right)$, com diferentes temperaturas de hibridização. Observa-se que para temperaturas menores $\left(25,35\right.$ e $\left.40^{\circ} \mathrm{C}\right)$ não houve seletividade do genossensor, ou seja, não distinguiu o que é a sequência complementar da sequência não complementar. No entanto, para $60{ }^{\circ} \mathrm{C}$ houve uma variação maior entre as sequências, indicando que a seletividade do genossensor será melhor para temperaturas mais altas.

Figura 24: Diferença do sinal $\left(|Z|-\left|Z_{0}\right|\right)(1 \mathrm{~Hz})$ em função Temperatura de hibridização, da sequência complementar (ds-DNA) e não complementar (nc-DNA) com concentração de $10^{-8} \mathrm{M}$, respectivamente.

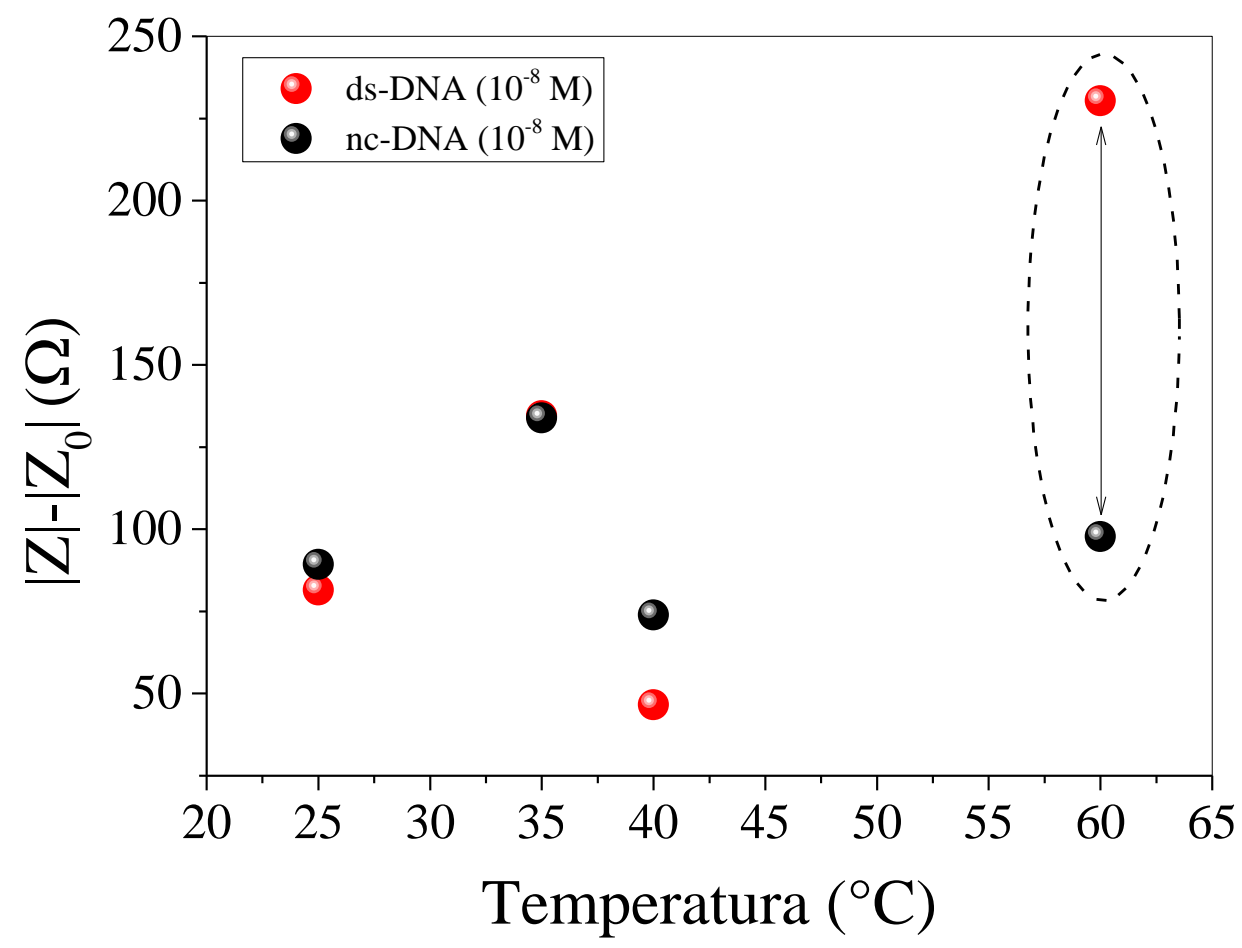

Fonte: Elaborado pela autora.

A partir desse último experimento, havia a expectativa de que a seletividade pudesse ser melhorada com a deposição de etanolamina para diminuir a adsorção não específica, se for usada uma alta temperatura. Empregando, assim, $60^{\circ} \mathrm{C}$ nos experimentos de hibridização, foram obtidos os espectros para concentrações da sequência complementar e não complementar, variando de $10^{-9}$ a $10^{-6} \mathrm{M}$. Os resultados das Figura 25a e Figura 25b mostram que a dependência com a concentração é até maior para a sequência não complementar. Isso quer dizer que o 
genossensor não foi seletivo, a despeito de a variação na impedância ter sido maior para a sequência complementar.

Figura 25: Espectros de impedância do genossensor com monocamada automontada de MAA em etanol, sonda ( $\mathrm{NH}_{2}$-ssDNA) e etanolamina. (a) sequência complementar (ds-DNA) e (b) não complementar (nc-DNA). Temperatura de hibridização fixa em $60^{\circ} \mathrm{C}$.

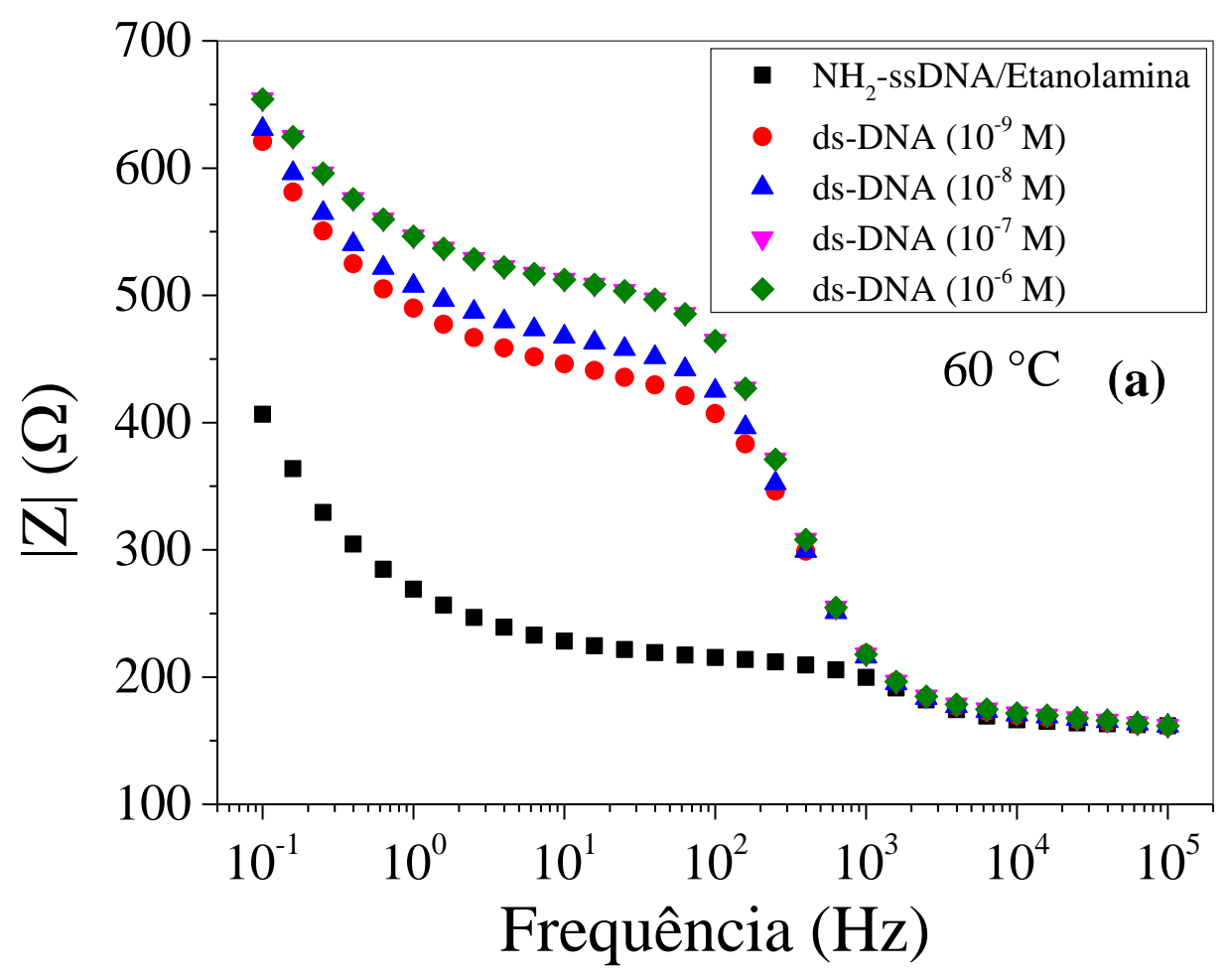

(continua) 


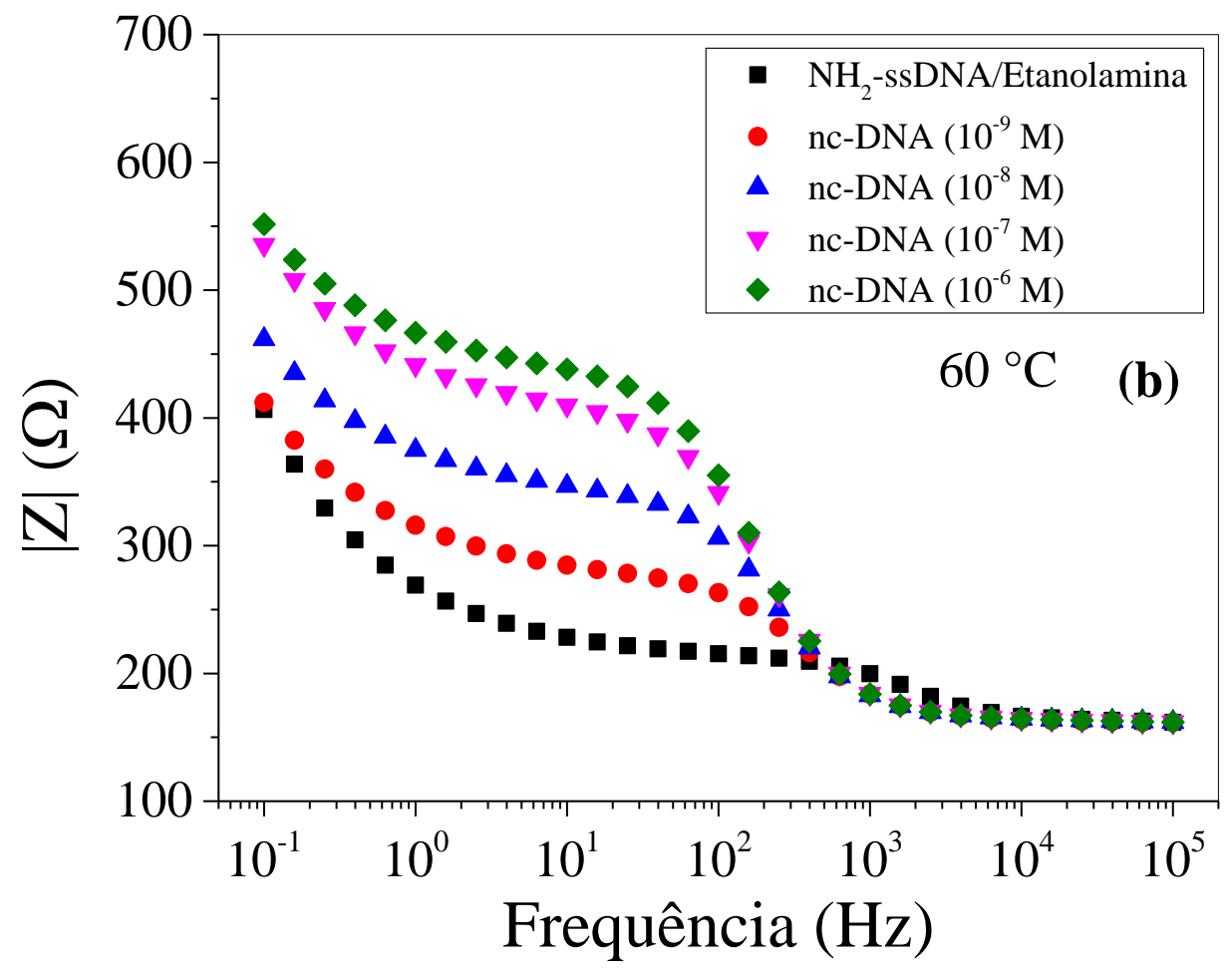

Fonte: Elaborado pela autora.

A falta de seletividade é melhor ilustrada nos gráficos de alteração na impedância da sequência $(|Z|)$ com relação à referência da sonda/etanolamina $\left(\left|Z_{0}\right|\right)$ em $1 \mathrm{~Hz}$ da Figura 26. A diferença de $|Z|-\left|Z_{0}\right|$ na impedância foi maior para a sequência complementar, porém a variação com a concentração foi menor, o que é visto como uma inclinação menor na dependência com a concentração. 
Figura 26: Diferença do sinal $\left(|Z|-\left|Z_{0}\right|\right)(1 \mathrm{~Hz})$ em função da concentração: sequência complementar (ds-DNA) e não complementar (nc-DNA).

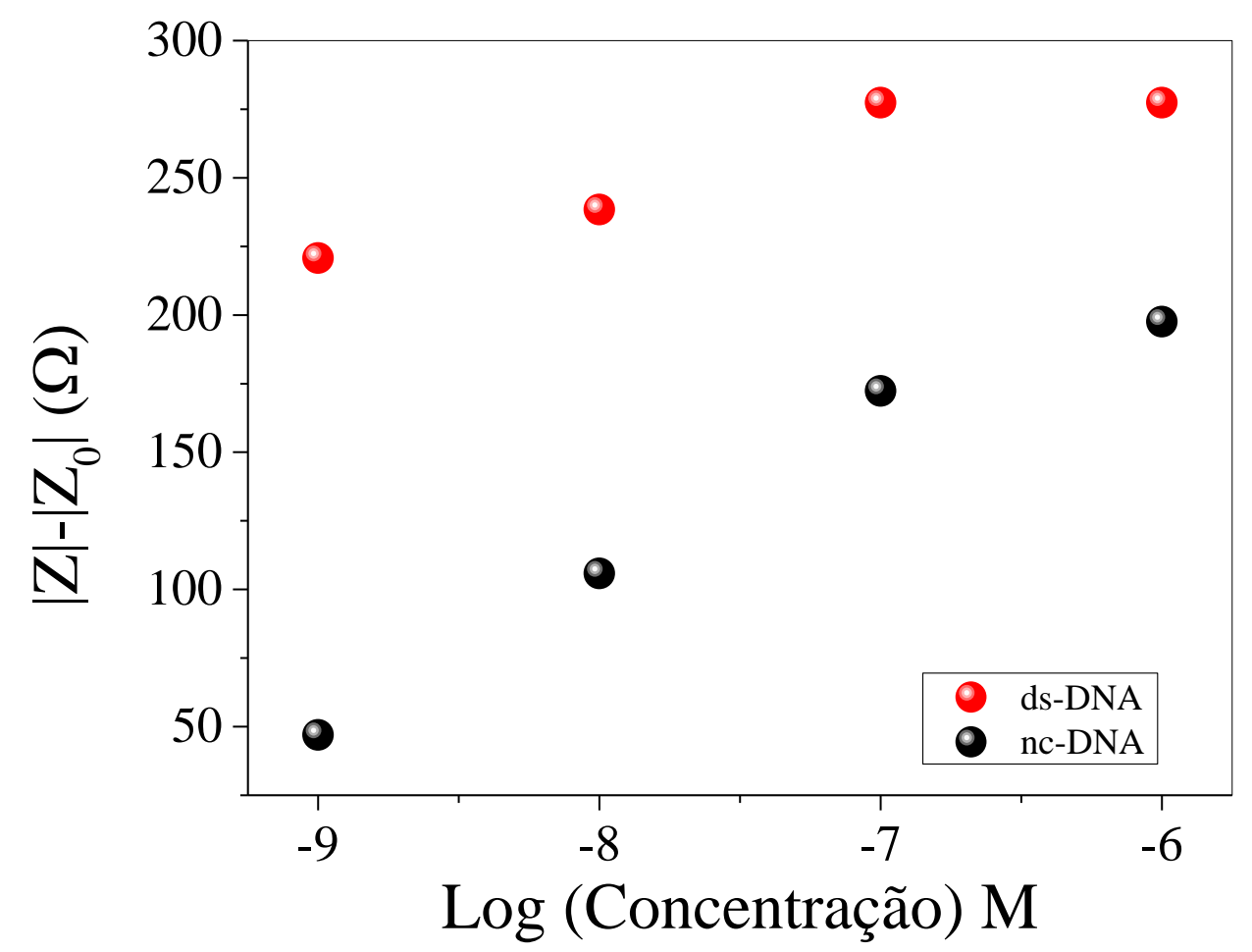

Fonte: Elaborado pela autora.

Várias outras tentativas foram feitas para obter genossensores seletivos, alterando-se parâmetros de manuseio das sequências de DNA. Segundo as informações (DataSheet) da Sigma-Aldrich sobre a sequência complementar, a temperatura de fusão $\left(T_{m}\right)$ dessa sequência é $76,8^{\circ} \mathrm{C}$. Utilizando como referência PCR Cycling Parameters-Six Key Considerations for Success (Parâmetros de Ciclo de PCR - Seis Principais Considerações para o Sucesso) no site da ThermoFisher (THERMOFISHER, 2019) verifica-se que a temperatura de hibridização deve ser igual a $T_{m}$ menos $5{ }^{\circ} \mathrm{C}$. Foram, então, realizados experimentos nessas condições, com temperatura de hibridização de $71,8{ }^{\circ} \mathrm{C}\left(\mathrm{T}_{\mathrm{m}}-5{ }^{\circ} \mathrm{C}\right)$. A Figura 27 mostra os espectros de impedância de cada etapa de construção do genossensor. Observa-se que o espectro da sonda ( $\mathrm{NH}_{2}$-ssDNA) coincide com o espectro da monocamada automontada de MAA, que indica que não houve adsorção da sonda na SAM. Depois a etanolamina foi imobilizada, com mudança pequena no espectro de impedância. No entanto, para a sequência complementar não houve distinção com o 
aumento da concentração.

Figura 27: Espectros de impedância, etapa por etapa, da construção do genossensor, a partir da monocamada automontada MAA, e medidas com a sequência complementar (ds-DNA) em diferentes concentrações. Temperatura de hibridização igual a $\mathrm{Tm}-5^{\circ} \mathrm{C}$.

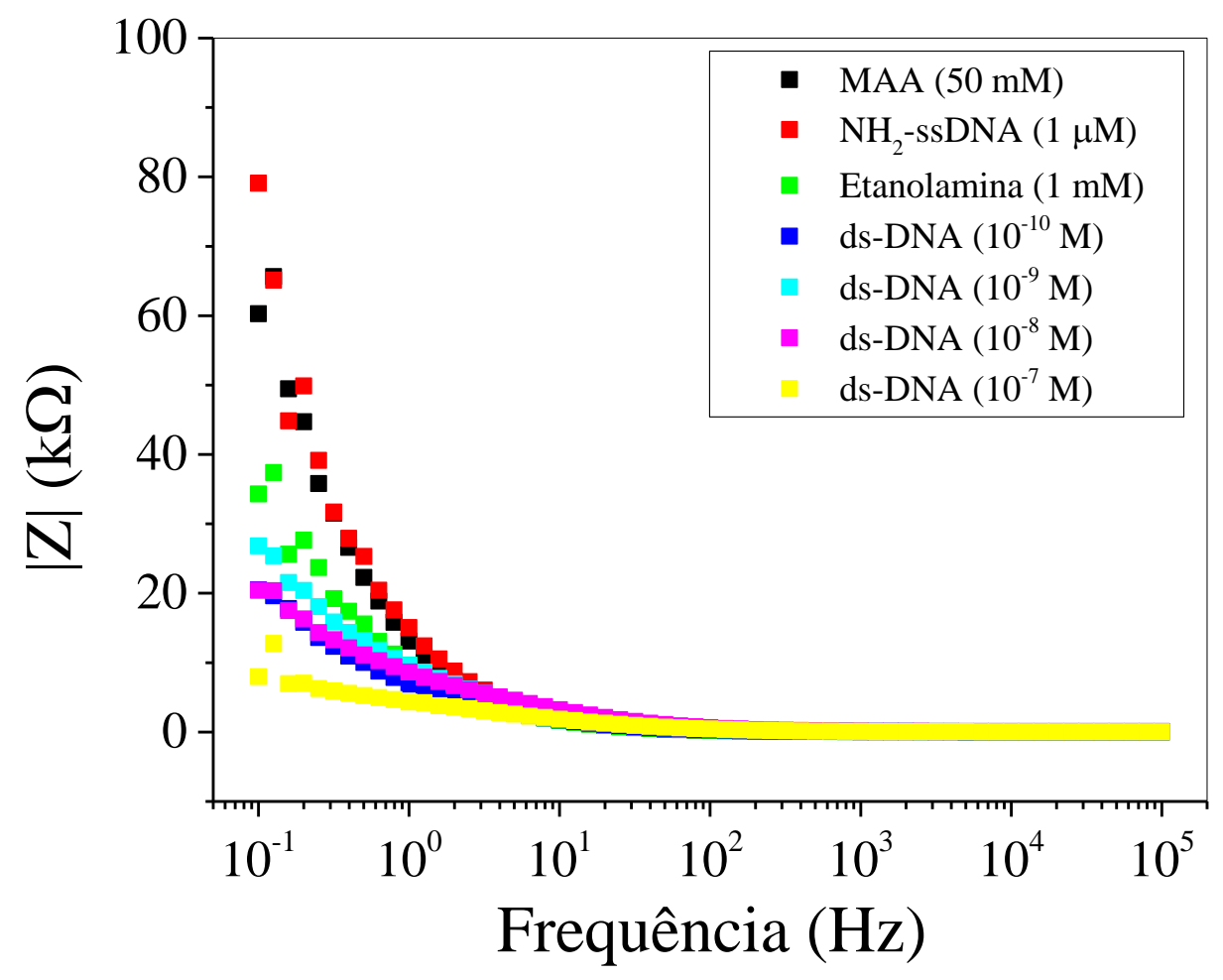

Fonte: Elaborado pela autora.

A diferença entre a impedância da sequência complementar (|Z|) em $1 \mathrm{~Hz}$ e da sonda/etanolamina $\left(\left|Z_{0}\right|\right)$ na Figura 28 indica uma dependência não monotônica com a concentração. Ou seja, não foi possível obter detecção com esses parâmetros. 
Figura 28: Diferença do sinal $\left(|Z|-\left|Z_{0}\right|\right)(1 \mathrm{~Hz})$ em função da concentração da sequência complementar (ds-DNA) com temperatura de hibridização igual a $\mathrm{Tm}-5^{\circ} \mathrm{C}$.

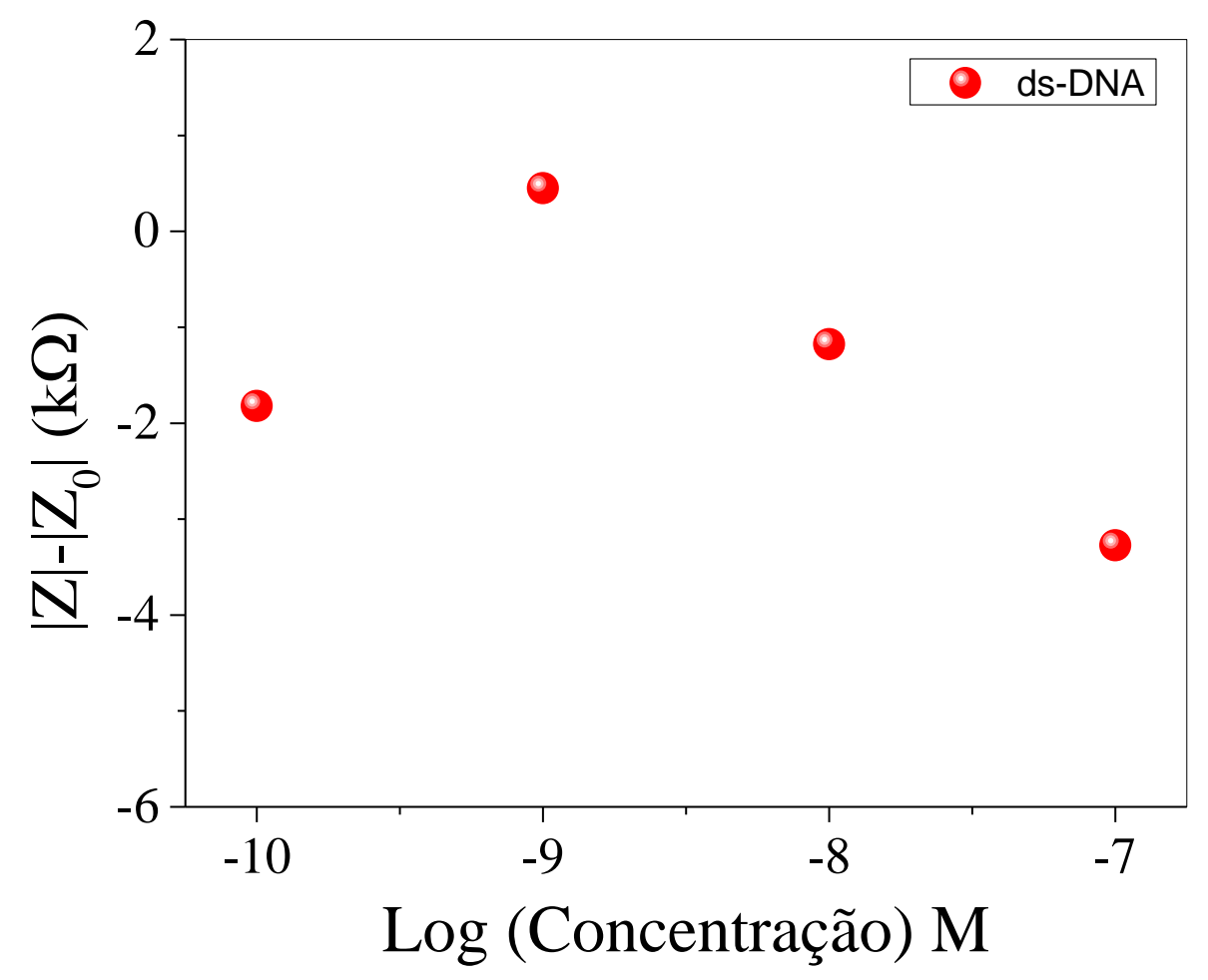

Fonte: Elaborado pela autora.

Em outro experimento, tentou-se uma temperatura de hibridização $5{ }^{\circ} \mathrm{C}$ a mais do que a $T_{m}$ (ou seja, utilizou-se $81,8^{\circ} \mathrm{C}$ ). Os resultados da

Figura 29, para a sequência complementar (a) e não complementar (b), mostram não ter havido mudança significativa nos espectros, não sendo possível distinguir as sequências. A Figura $\mathbf{3 0}$ apresenta a curva analítica dos espectros da

Figura 29 em $1 \mathrm{~Hz}$, em que se observa uma alteração na impedância maior para a sequência não complementar. Em suma, nessas condições o genossensor não distinguiu a concentração, nem as sequências como o esperado. 
Figura 29: Espectros de impedância, etapa por etapa, da construção do genossensor, a partir da monocamada automontada MAA para a sequência complementar (ds-DNA) em diferentes concentrações com a temperatura de hibridização igual a $\mathrm{Tm}+5^{\circ} \mathrm{C}$.

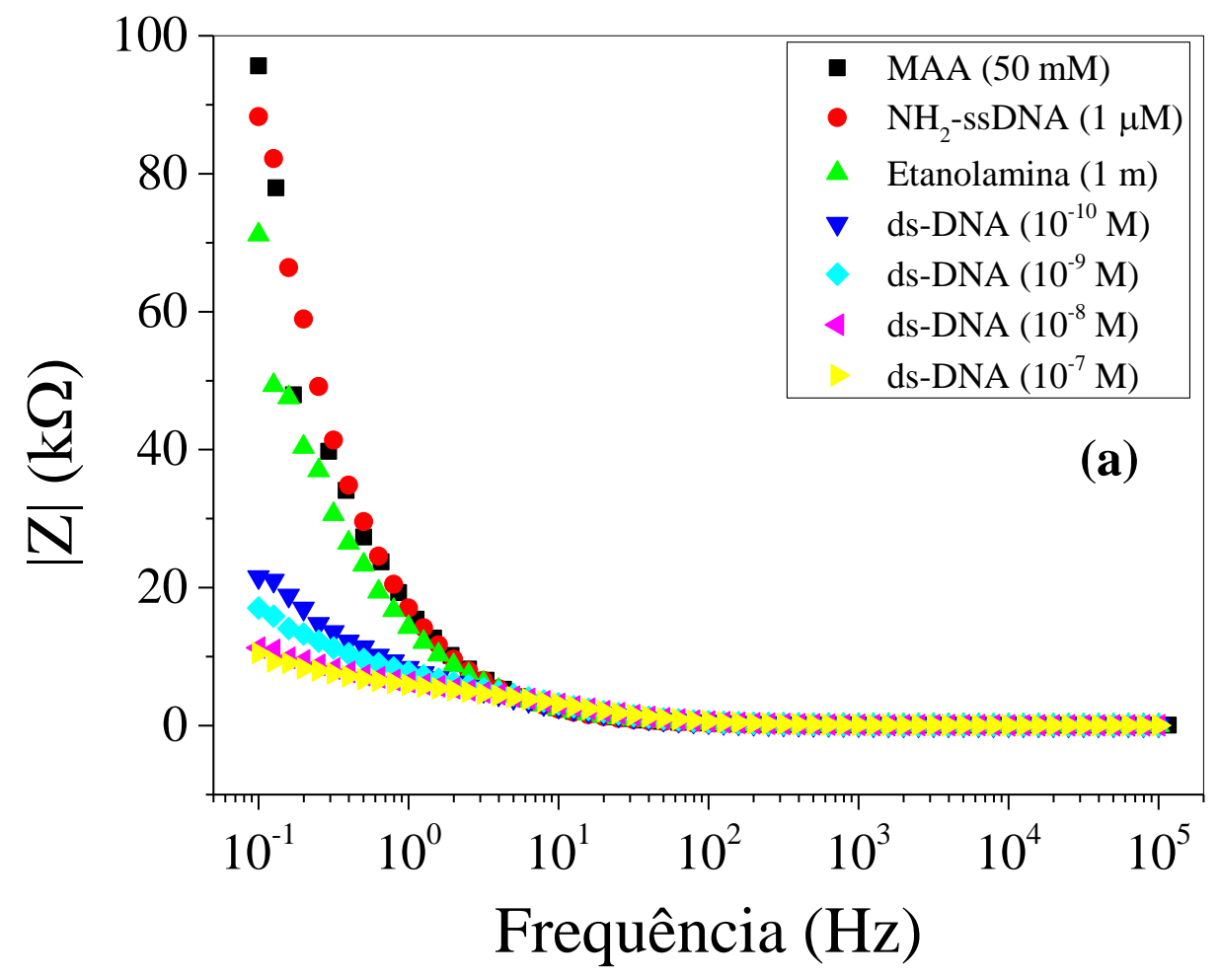




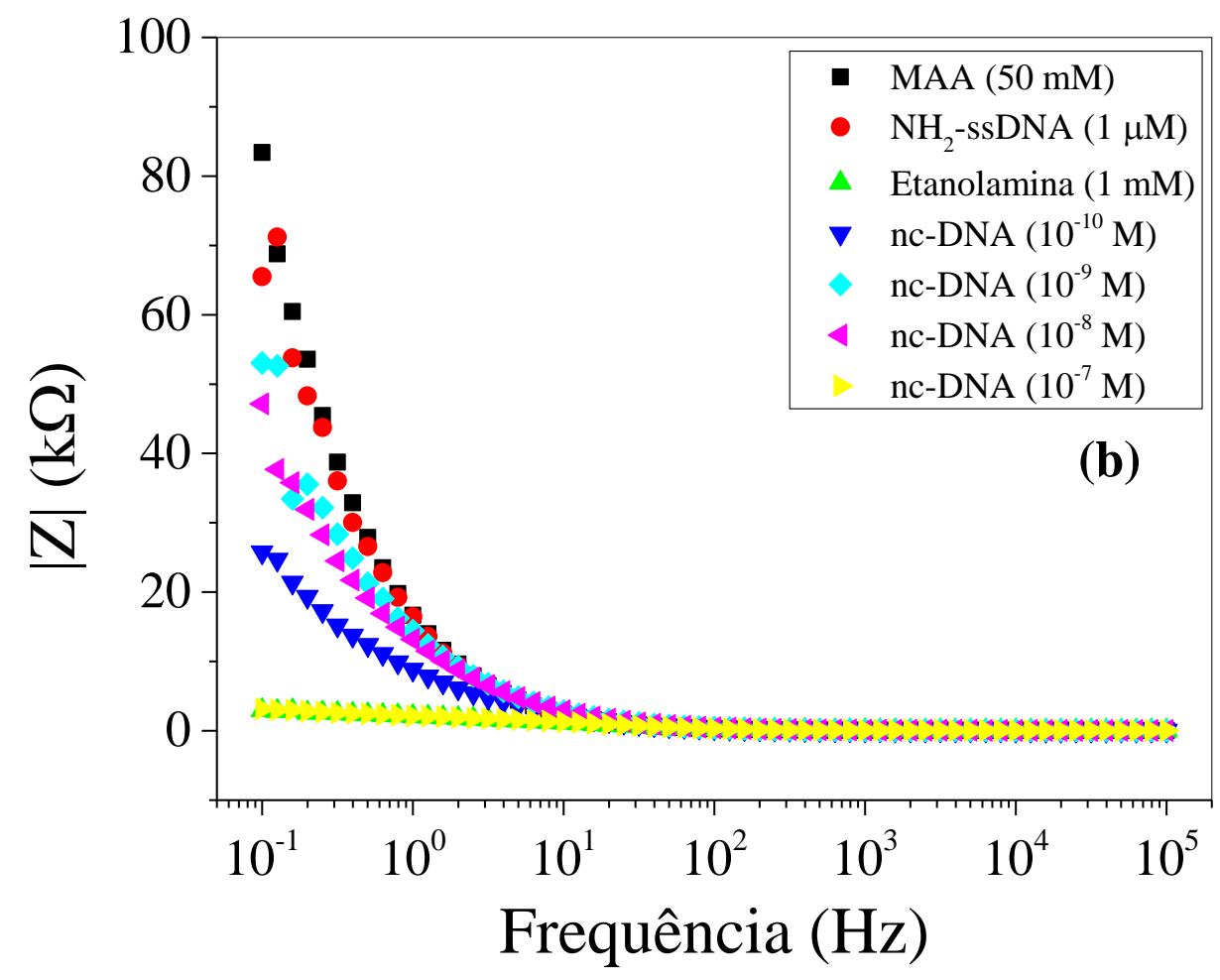

Fonte: Elaborado pela autora.

Figura 30: Diferença do sinal $\left(|Z|-\left|Z_{0}\right|\right)(1 \mathrm{~Hz})$ em função da concentração da sequência complementar (ds-DNA) e não complementar (nc-DNA) com temperatura de hibridização igual a Tm + $5{ }^{\circ} \mathrm{C}$.

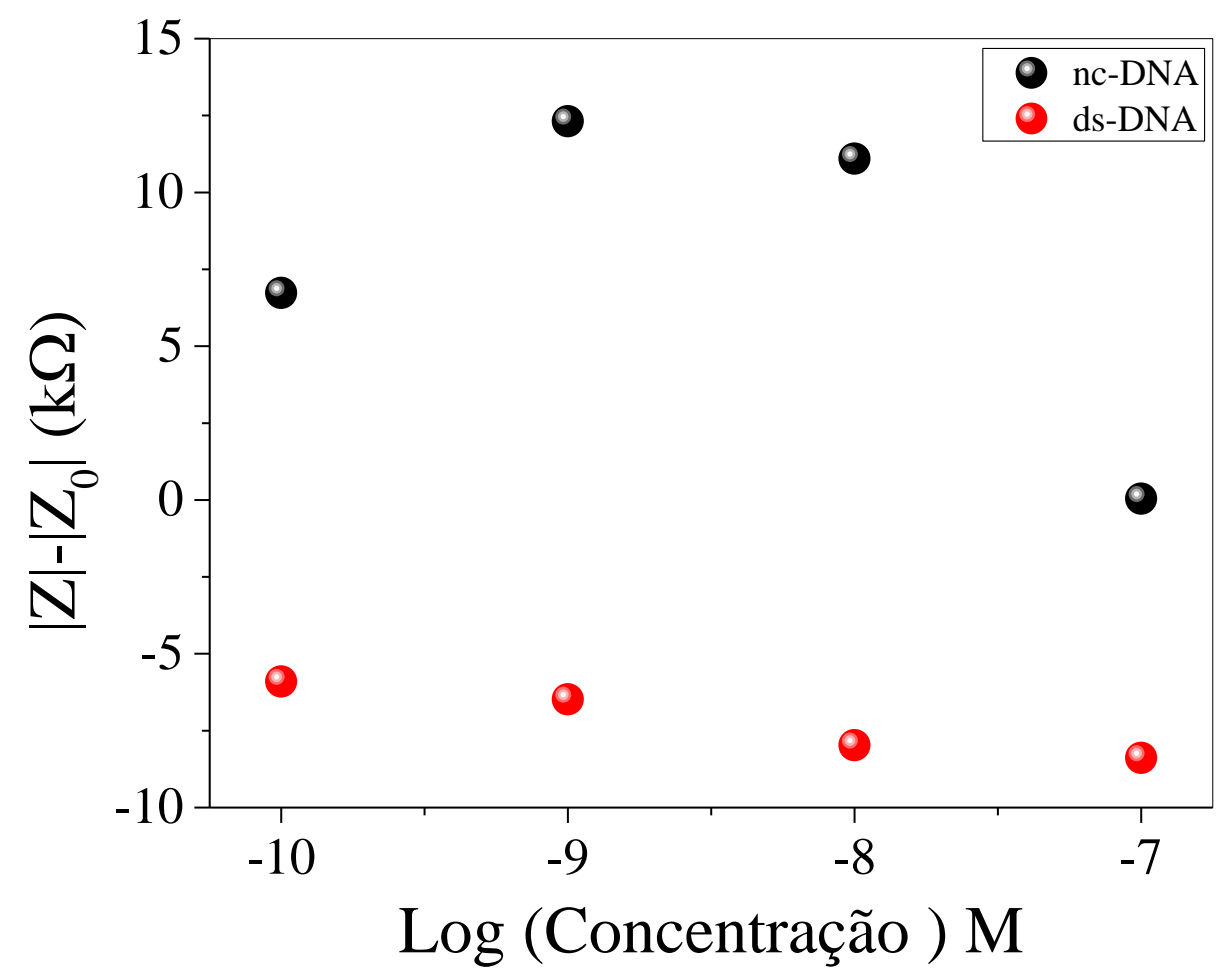


Fonte: Elaborado pela autora.

Mantendo-se as mesmas condições do experimento anterior, a temperatura de hibridização foi alterada para $T_{m}+10{ }^{\circ} \mathrm{C}$, ou seja $86,8{ }^{\circ} \mathrm{C}$. As Figura $31(\mathrm{a})$ e (b) mostram os resultados para as sequências complementar e não complementar, respectivamente. Observa-se alteração no espectro de ds-DNA para cada concentração, ao contrário do que ocorreu com nc-DNA. Este resultado parece indicar seletividade.

Figura 31: Espectros de impedância, etapa por etapa, da construção do genossensor, a partir da monocamada automontada MAA para a sequência complementar (ds-DNA) em diferentes concentrações com a temperatura de hibridização de $\mathrm{Tm}+10{ }^{\circ} \mathrm{C}$.

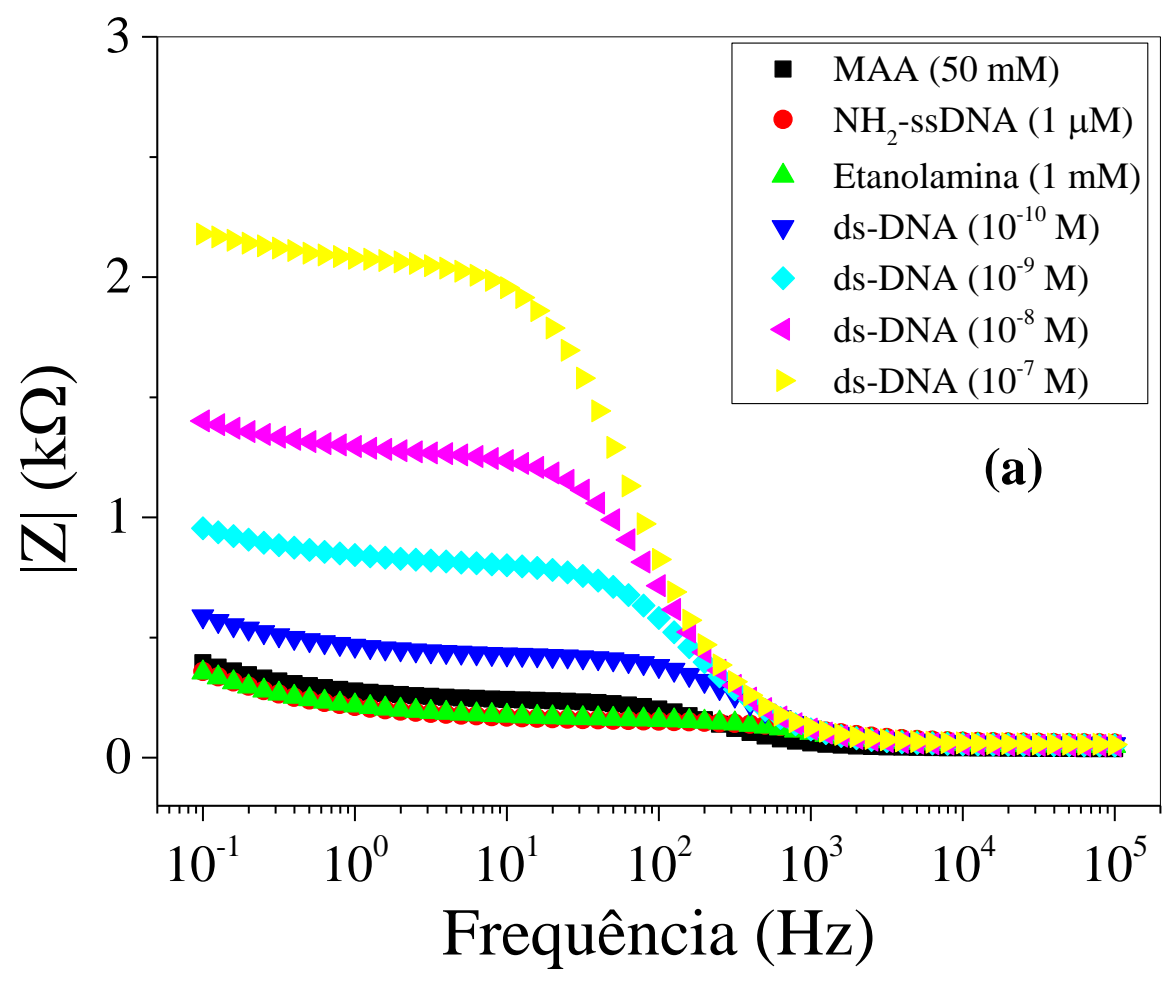




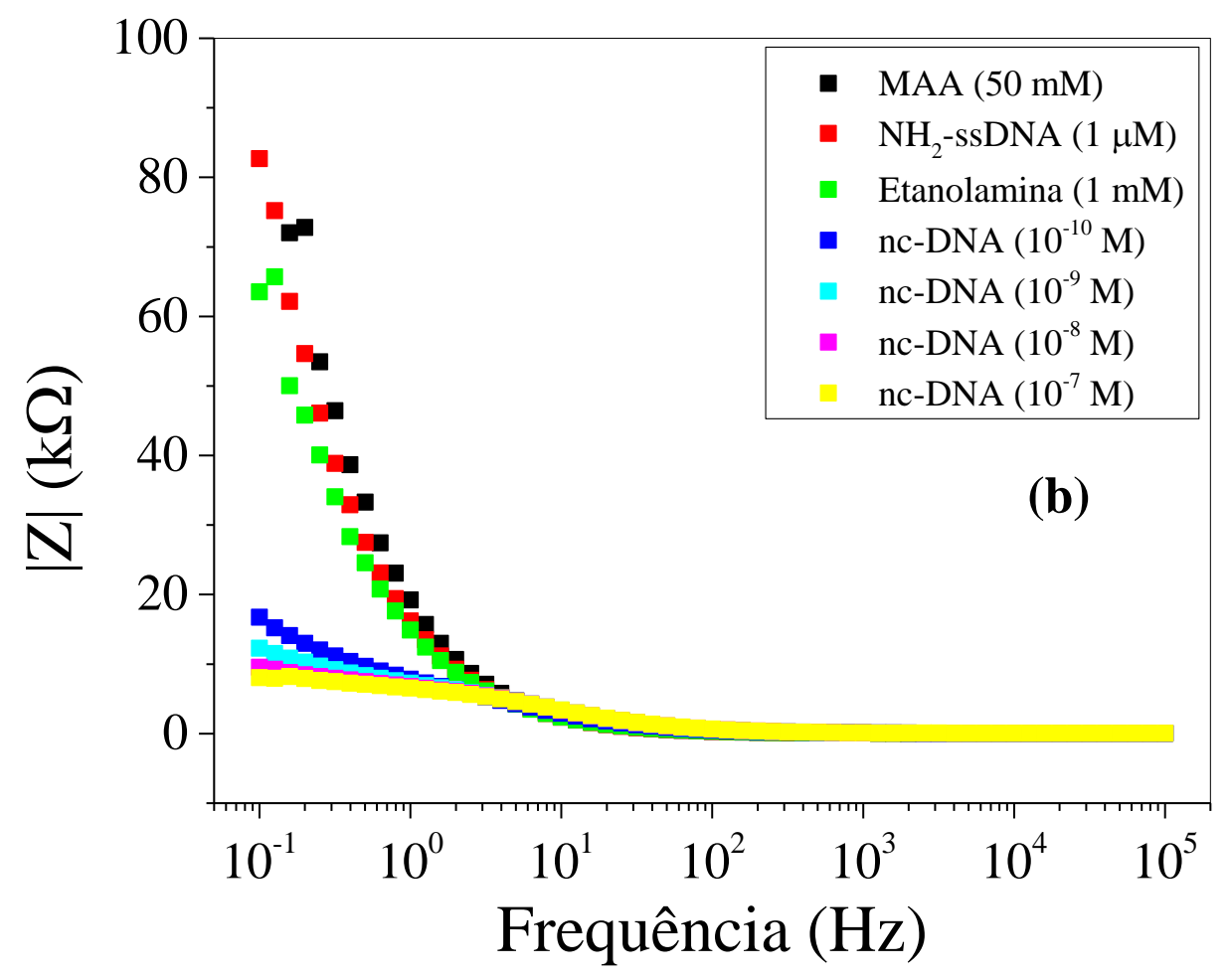

Fonte: Elaborado pela autora.

As curvas analíticas para a diferença de impedância em $1 \mathrm{~Hz}$ são mostradas na Figura 32, em que se nota maior diferença para a sequência complementar. Existe, porém, um problema a ser solucionado nesse genossensor, pois a sensibilidade é muito baixa, com alteração de impedância de aproximadamente 1 $k \Omega$.

Figura 32: Diferença do sinal $\left(|Z|-\left|Z_{0}\right|\right)(1 \mathrm{~Hz})$ em função da concentração da sequência complementar (ds-DNA) e não complementar (nc-DNA) com temperatura de hibridização igual a Tm $+10^{\circ} \mathrm{C}$. 


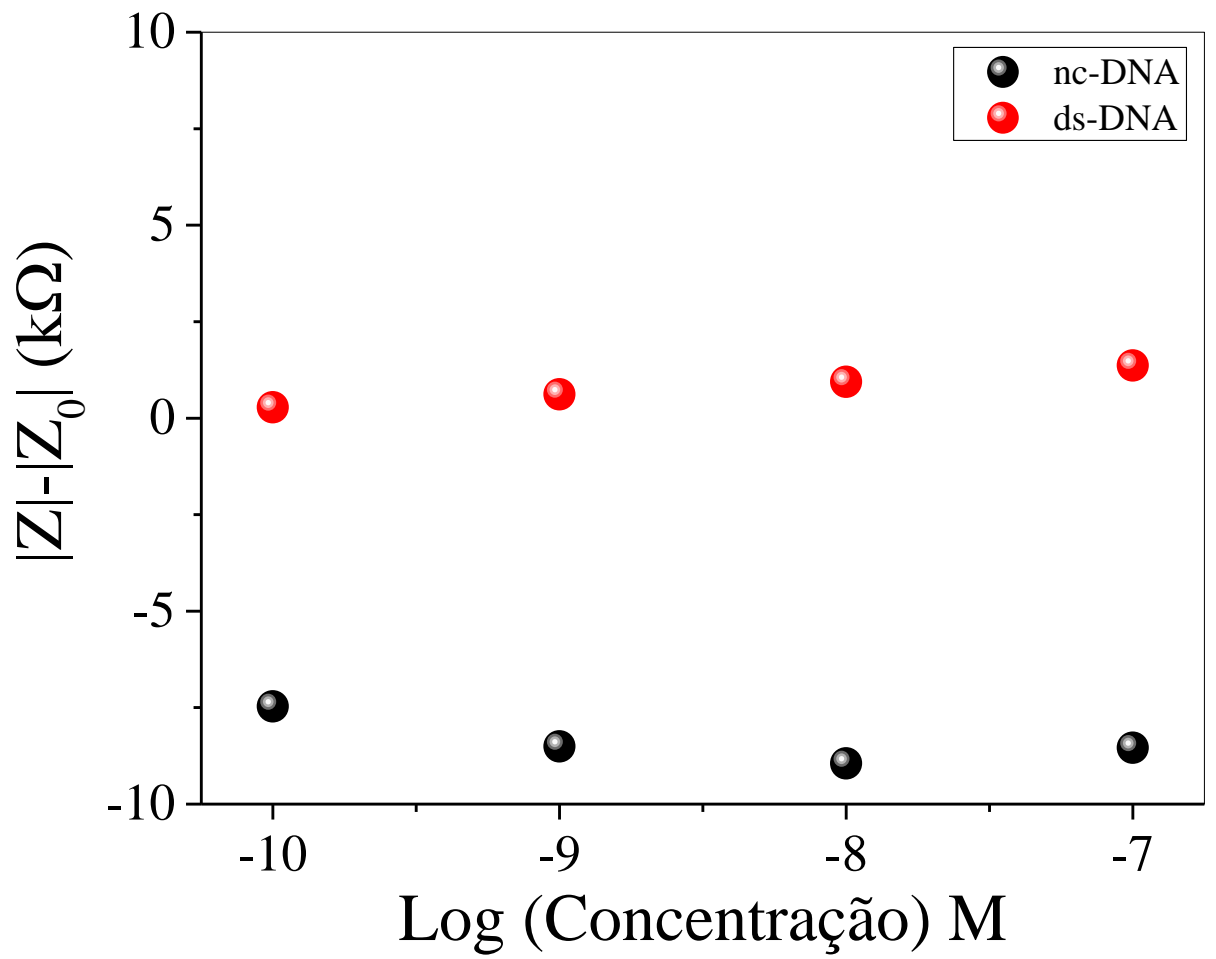

Fonte: Elaborada pela autora.

Para confirmar se esse genossensor estava realmente funcionando, repetiu-se o experimento anterior com $\mathrm{T}_{\mathrm{m}}+10^{\circ} \mathrm{C}\left(86,8{ }^{\circ} \mathrm{C}\right)$ e todas as outras condições. Os espectros da Figura 33 não são distintos para as diferentes concentrações da sequência complementar, ao contrário do observado na Figura 31. Isso significa que os resultados com esse genossensor não são reprodutíveis. 
Figura 33: Espectros de impedância, etapa por etapa, da construção do genossensor, a partir da monocamada automontada MAA para a sequência complementar (ds-DNA) em diferentes concentrações com temperatura de hibridização igual a $\mathrm{Tm}+10^{\circ} \mathrm{C}$

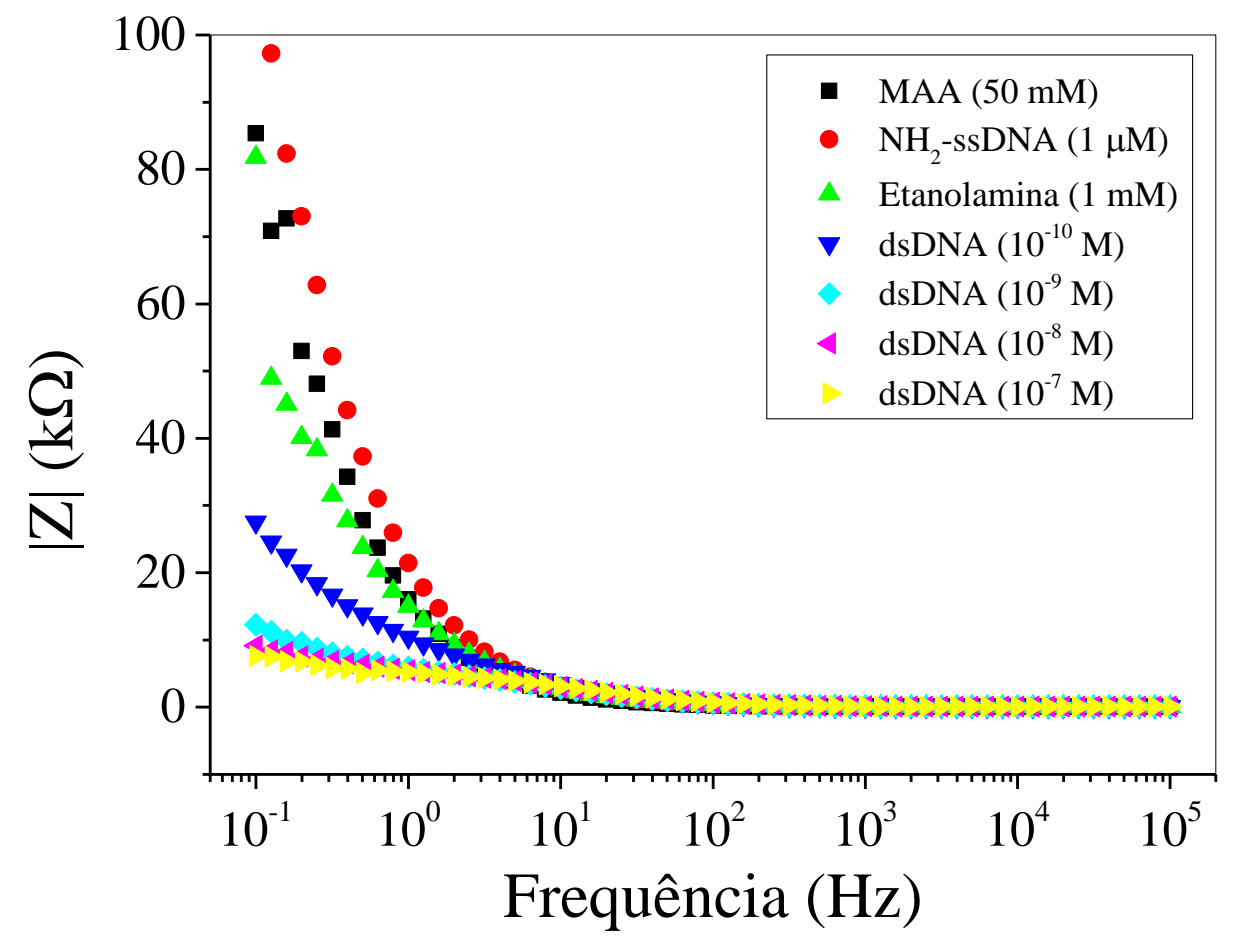

Fonte: Elaborado pela autora.

Outra evidência da falta de reprodutibilidade é vista na

Figura 34, em que se construiu uma curva analítica para os dados da Figura 33. Diferentemente do esperado, a variação na impedância não aumenta com a concentração da sequência complementar. 
Figura 34: Diferença do sinal $\left(|Z|-\left|Z_{0}\right|\right)(1 \mathrm{~Hz})$ em função da concentração da sequência complementar (ds-DNA) com temperatura de hibridização igual a $\mathrm{Tm}+10^{\circ} \mathrm{C}$.

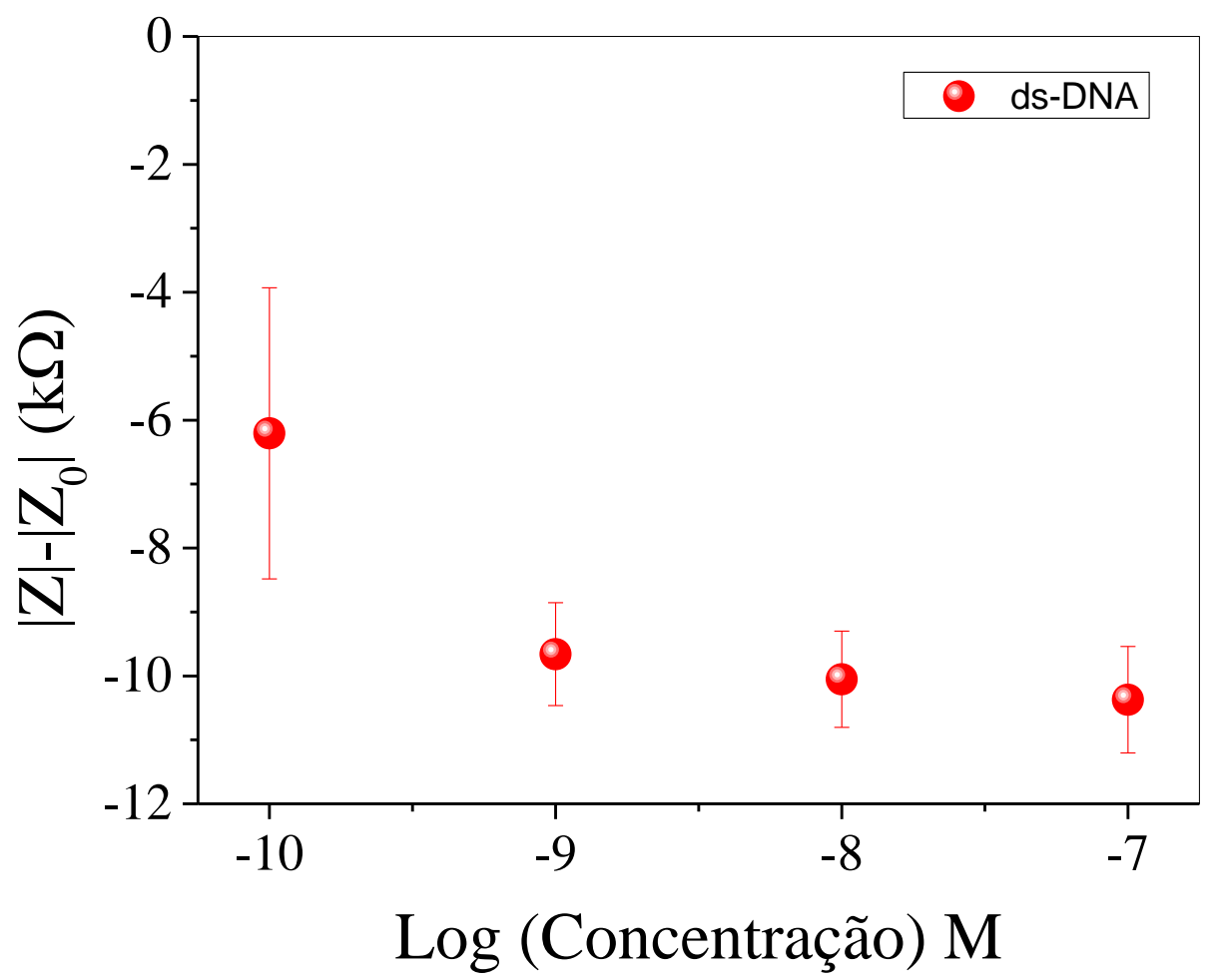

Fonte: Elaborado pela autora.

Dos resultados desta seção ficou claro que os genossensores não são eficazes com a metodologia e arquitetura molecular utilizadas. Como várias condições de hibridização foram tentadas sem sucesso, restou verificar se o problema não estaria no filme automontado, pois sabe-se da literatura (STEEL; HERNE; TARLOV, 1998) que a organização das biomoléculas (neste caso a sequência de DNA) deve ser adequada para que a hibridização seja eficiente. Duas iniciativas foram tomadas: realizar experimentos de SFG para verificar a organização da sequência de prova e alterar o material do filme automontado. Os resultados de SFG são mostrados abaixo, e confirmaram que a organização da monocamada SAM de MAA não era adequada. Por isso, passou-se a empregar um ácido correspondente com cadeia maior, o ácido mercaptoundecanóico (MUA), levando a resultados promissores de genossensores. Os resultados promissores são mostrados na Seção 4.3. 


\subsubsection{Medidas de SFG}

A Figura 35 mostra espectros de SFG para as amostras de MAA com diferentes tempos de imobilização (1 a 60 dias) em etanol. As amostras foram preparadas em substratos de ouro diferentes, para que as medidas fossem realizadas no mesmo dia. Nas amostras com 30 e 60 dias observou-se uma banda em $1250 \mathrm{~cm}^{-1}$ atribuída ao estiramento da ligação C-O do grupo (SONG; LIU; HE, 2008). Para que apareça um sinal no SFG é necessário que haja orientação média resultante das moléculas, o que pode ser observado apenas nas amostras com mais de 30 dias de imobilização. Nas amostras com menos tempo de imobilização (1, 7, e 14 dias) não se observou sinal no SFG, devido à orientação aleatória do MAA. Para o MUA não foi feito estudo de organização, pois já há resultados na literatura para essa molécula. De fato, o estudo de Casford, et.al. (CASFORD et al., 2014) mostrou que com 1 dia de imobilização em etanol obtém-se uma monocamada organizada. 
Figura 35: Espectros de SFG monocamada automontada (SAM) de ácido mercaptoacético (MAA) imobilizada em diferentes tempos
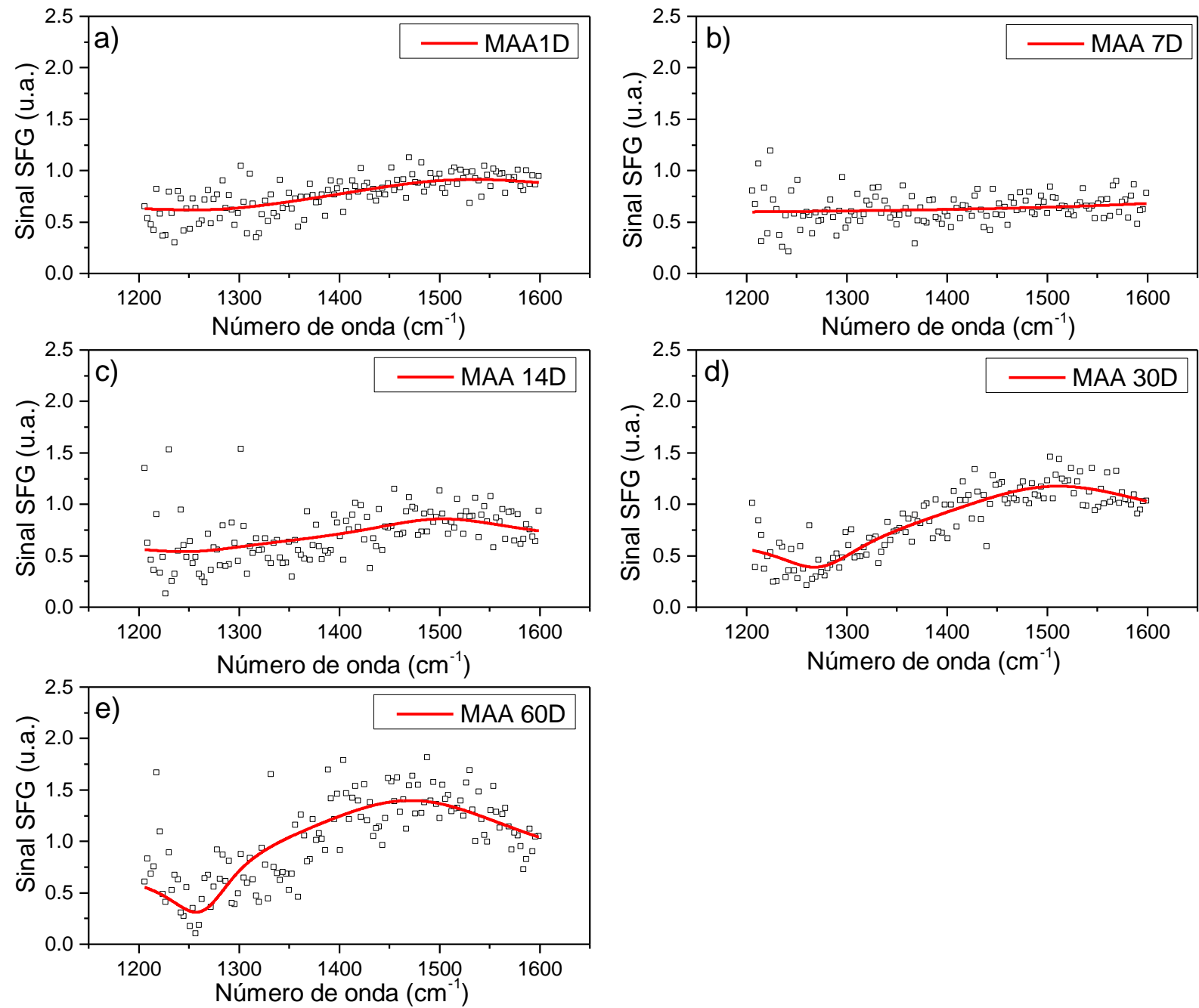

Fonte: Elaborado pela autora.

Os resultados de SFG para os filmes de MAA foram cruciais para explicar as falhas nas tentativas de obter genossensores eficazes com MAA. Infelizmente, esses resultados só foram obtidos após essas tentativas, pois não se vislumbrou inicialmente que filmes de MAA não seriam apropriados para os genossensores. Uma das principais conclusões, portanto, é que experimentos como os de PMIRRAS e SFG podem ser excelentes para triagem de materiais e condições de fabricação para genossensores, e provavelmente outros tipos de biossensores também. Esse experimento foi feito em colaboração com Prof. Dr. Paulo Barbeitas Miranda no laboratório de espectroscopia não linear (LENI) do Instituto de Física de São Carlos. 


\subsection{Detecção com filme SAM de MUA}

A caracterização eletroquímica foi usada para investigar a imobilização da sonda ( $\mathrm{NH}_{2}$-ssDNA) e a hibridização das sequências complementar (ds-DNA) e não complementar (nc-DNA). Essas medidas foram realizadas em $5 \mathrm{mM}$ de ferrocianeto e ferricianeto de potássio $\left(\mathrm{K}_{3}\left[\mathrm{Fe}(\mathrm{CN})_{6}\right] / \mathrm{K}_{4}\left[\mathrm{Fe}(\mathrm{CN})_{6}\right]\right)$ em $\mathrm{PBS} \mathrm{MgCl}_{2}(1 \mathrm{mM})$. Os eletrodos foram preparados com diferentes plataformas (SAM), usando MUA (50 $\mathrm{mM}$ ) em etanol, ambos imobilizados por 1 dia. Quando esses experimentos foram executados, ainda não se sabia que para o MAA 1 dia não era suficiente para ter organização da monocamada. Estes testes de detecção serviram também para otimização do tempo.

A Figura 35 mostra os espectros de impedância eletroquímica etapa por etapa da construção do genossensor, a partir da monocamada automontada (SAM) de ácido mercaptoundecanóico (MUA) em etanol sobre o eletrodo de ouro. $O$ espectro foi alterado, com impedância de 162,12 k $\Omega$ em $1 \mathrm{~Hz}$. Depois de imobilizada a sonda $\left(\mathrm{NH}_{2}\right.$-ssDNA), a impedância era de $7,88 \mathrm{k} \Omega$, ou seja, menor que a impedância do MUA. Isso pode ser explicado pela cadeia longa do MUA (11 carbonos), que aumenta a resistência ao transporte da carga. A impedância da sonda diminui devido à organização da mesma sobre a SAM, indicando que a sonda modificou a superfície do eletrodo. Porém, a etanolamina imobilizada depois da sonda para bloquear os sítios teve a impedância muito próxima da sonda $(6,97 \mathrm{k} \Omega)$. Esse resultado pode ser devido à não imobilização da etanolamina ou à organização das moléculas, já que essa molécula tem 2 carbonos em sua cadeia. 
Figura 36: Espectros de impedância, etapa por etapa, da construção do genossensor, a partir da monocamada automontada MUA em etanol.

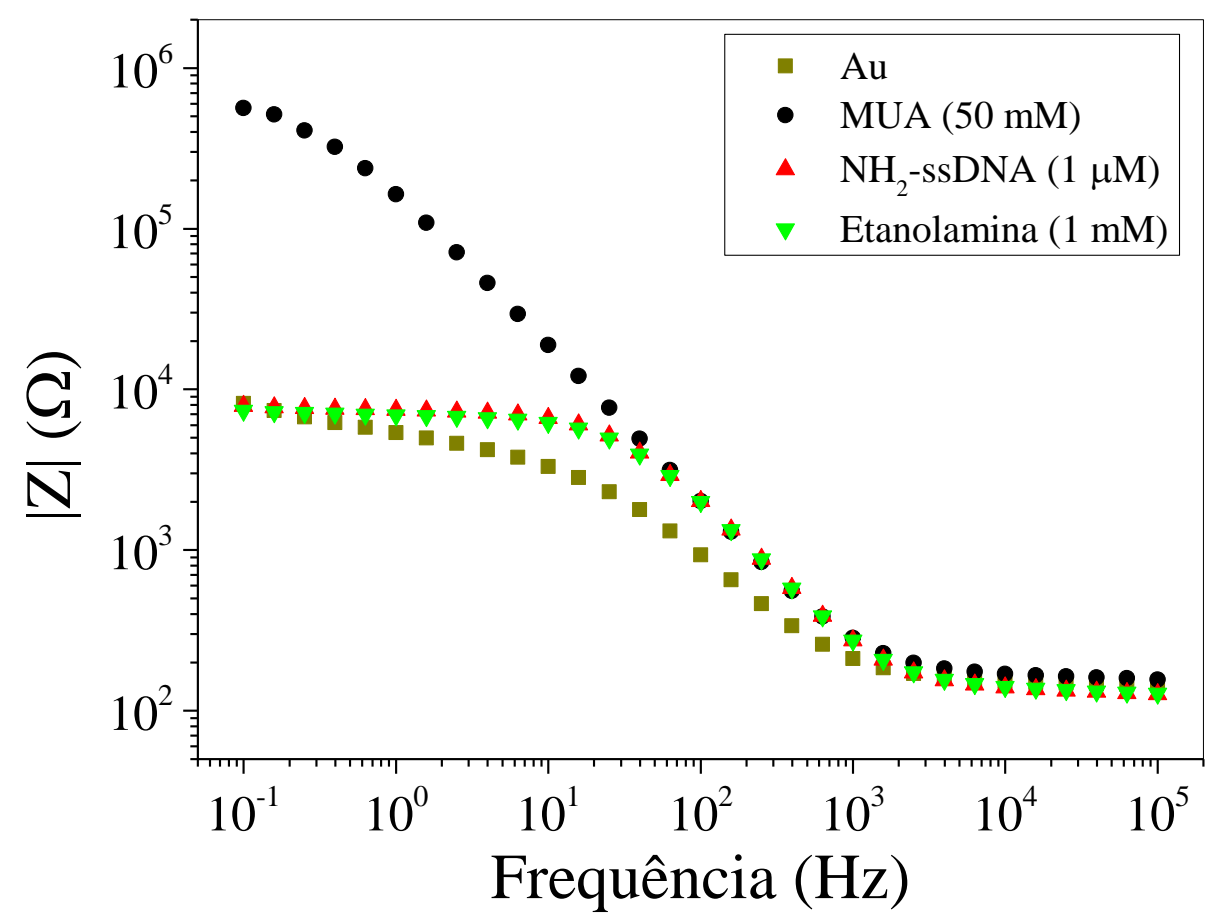

Fonte: Elaborado pela autora.

Os espectros de impedância eletroquímica da

Figura 37 se referem aos sensores construídos com a monocamada automontada de ácido mercaptoundecanoico (MUA), com diferentes concentrações de sequência complementar (ds-DNA) e não complementar (nc-DNA) $\left(10^{-11}\right.$ a $10^{-6}$ M). A

Figura 37a mostra o espectro de impedância para a sequência complementar, em que a impedância aumenta com a concentração devido à hibridização da sequência complementar com a sonda. $A$

Figura 37b mostra espectros da sequência não complementar para diferentes concentrações, em que a impedância variou pouco, com valor próximo da impedância para etanolamina $(6,97 \mathrm{k} \Omega$ em $1 \mathrm{~Hz})$. Ou seja, há apenas um pouco de adsorção. 
Figura 37: Espectros de impedância dos genossensores construídos a partir da monocamada automontada de MUA em etanol, com diferentes concentrações da sequência complementar (dsDNA) (a) e da sequência não complementar (nc-DNA).
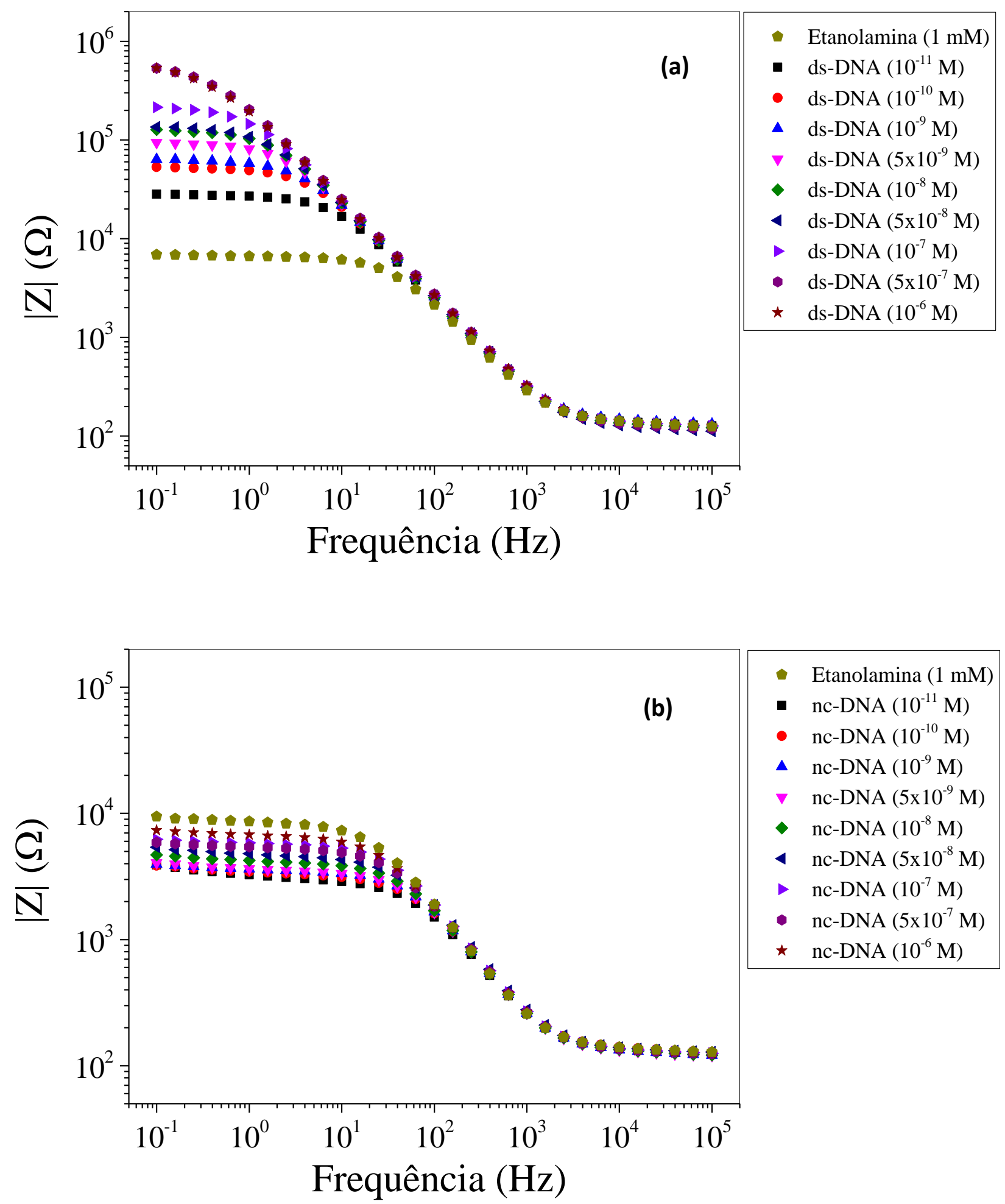

Fonte: Elaborado pela autora. 


\subsection{Curva Analítica}

Foi estudado o comportamento da hibridização da sequência complementar (ds-DNA) e não complementar (nc-DNA) com diferentes concentrações, entre $10^{-11}$ a $10^{-6}$ M. Esse teste foi realizado por impedância eletroquímica em $5 \mathrm{mM}$ de ferrocianeto e ferricianeto de potássio $\left(\mathrm{K}_{3}\left[\mathrm{Fe}(\mathrm{CN})_{6}\right] / \mathrm{K}_{4}\left[\mathrm{Fe}(\mathrm{CN})_{6}\right]\right)$ em $\mathrm{PBS} / \mathrm{MgCl}_{2}(1$ $\mathrm{mM}$ ). Os espectros foram analisados na frequência de $1 \mathrm{~Hz}$, obtendo a diferença do sinal da sequência-controle menos o sinal $\mathrm{NH}_{2}$-ssDNA/Etanolamina $\left(|\mathrm{Z}|-\left|\mathrm{Z}_{0}\right|\right)$. A Figura 38 apresenta a diferença de sinal em função do log da concentração para o genossensor construído com MUA, pois foi a plataforma que obteve melhor distinção das sequências de DNA. Após a hibridização, as medidas de impedância eletroquímica mostraram aumento do sinal em função do aumento da concentração da sequência complementar (ds-DNA). Quando a sonda $\left(\mathrm{NH}_{2}\right.$-SsDNA) hibridiza com a sequência complementar, forma-se uma estrutura de dupla hélice deixando expostos os grupos fosfato eletronegativos na superfície. Isso dificulta a espécie $\left[\mathrm{Fe}(\mathrm{CN})_{6}\right]^{-3 /-4}$ atingir o eletrodo devido à repulsão eletrostática, aumentando a impedância. Em outro eletrodo foi analisada a sequência não complementar (ncDNA), que apresentou um sinal independente (não variável) da concentração. A curva analítica é linear com o logaritmo da concentração de ssDNA, enquanto alterações insignificantes foram observadas para o nc-DNA. Para $\mathrm{NH}_{2}$-SsDNA, a faixa de concentração linear entre $1,0 \times 10^{-11}$ e $5,0 \times 10^{-8} \mathrm{M}$ e entre $1,0 \times 10^{-8}$ e 1,0 $\times 10^{-6} \mathrm{M}$ pode ser ajustada com a equação de regressão $\left(|Z|-\left|Z_{0}\right|\right)=199.150,21+$ $15.772,64 \log C$ e $\left(|Z|-\left|Z_{0}\right|\right)=517.319,07+54.125,61 \log C$, em que $C$ é a concentração de ssDNA. O limite de detecção é de 0,24 e $277 \times 10^{-12} \mathrm{M}$, correspondente a cada faixa linear, estimada usando LOD $=3 S D / \theta$, sendo $\theta$ a inclinação e SD o desvio padrão da regressão linear. Foram realizadas três medidas para cada concentração de DNA e calculado o desvio padrão. 
Figura 38: Curva analítica obtida dos espectros de impedância eletroquímica na frequência de $1 \mathrm{~Hz}$, com diferentes concentrações da sequência complementar (ds-DNA) e não complementar (nc-DNA), a partir da SAM com MUA.

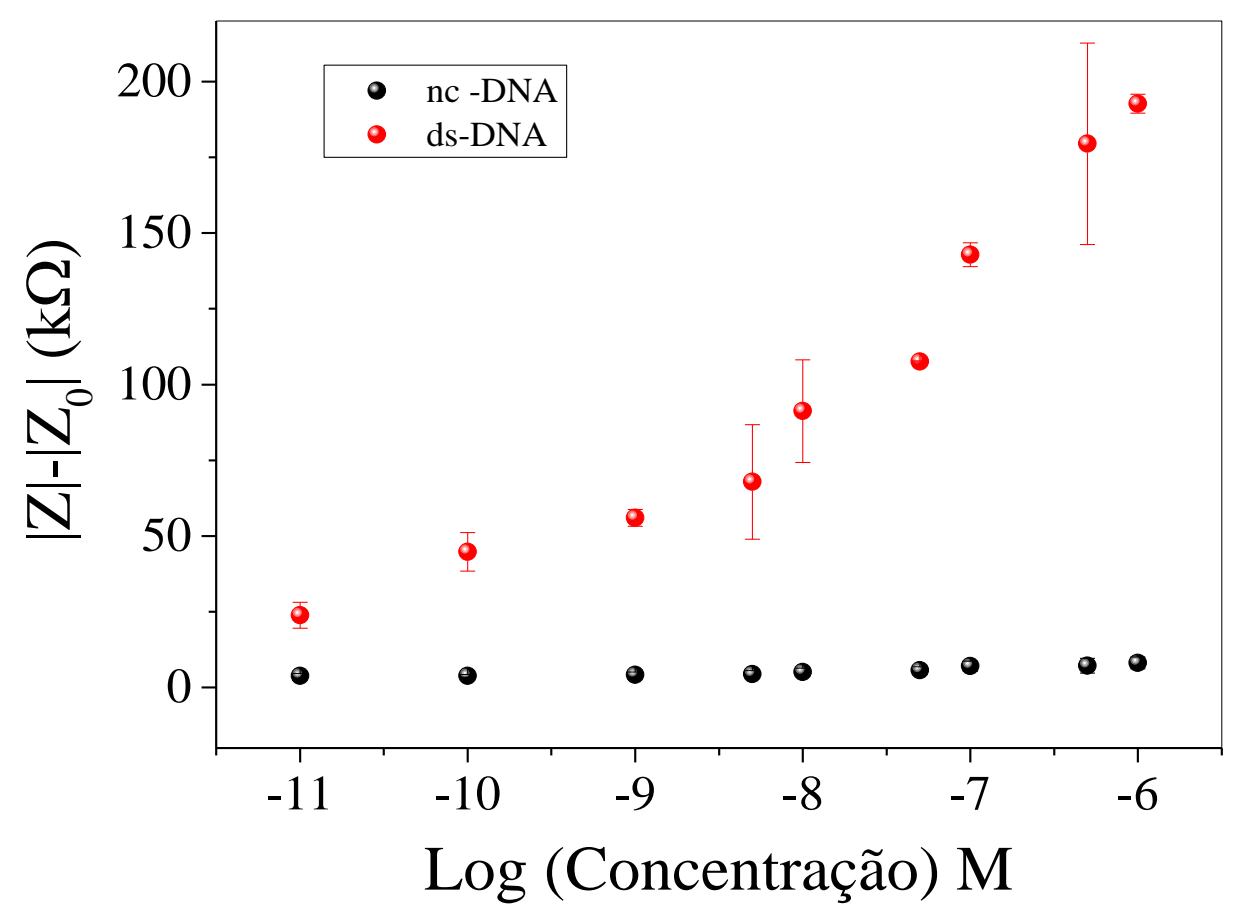

Fonte: Elaborado pela autora.

\subsection{Interferentes}

O teste de seletividade para o genossensor foi feito com a plataforma contendo a monocamada automontada de MUA, para diferentes sequências de DNA, sequência complementar (ds-DNA), 1 base trocada (1b-DNA) e a sequência não complementar (nc-DNA). As medidas de impedância eletroquímica foram feitas em 5 $\mathrm{mM}$ de ferrocianeto e ferricianeto de potássio $\left(\mathrm{K}_{3}\left[\mathrm{Fe}(\mathrm{CN})_{6}\right] / \mathrm{K}_{4}\left[\mathrm{Fe}(\mathrm{CN})_{6}\right]\right)$ em $\mathrm{PBS} / \mathrm{MgCl}_{2}$ (1 $\mathrm{mM}$ ). Foram analisados os espectros de impedância de cada sequência com concentração de $1 \mu \mathrm{M}$ (Figura 39), comparando a diferença do sinal das sequências controle e o sinal da última etapa de preparação do sensor $\left(\mathrm{NH}_{2}\right.$ ssDNA/Etanolamina) $\left(|Z|-\left|Z_{0}\right|\right)$. 
Figura 39: Espectros de impedância dos genossensores construídos a partir da monocamada automontada de MUA em etanol, da sequência complementar (ds-DNA), sequência com 1 base trocada (1b-DNA) e da sequência não complementar (nc-DNA), com $1 \mu \mathrm{M}$.

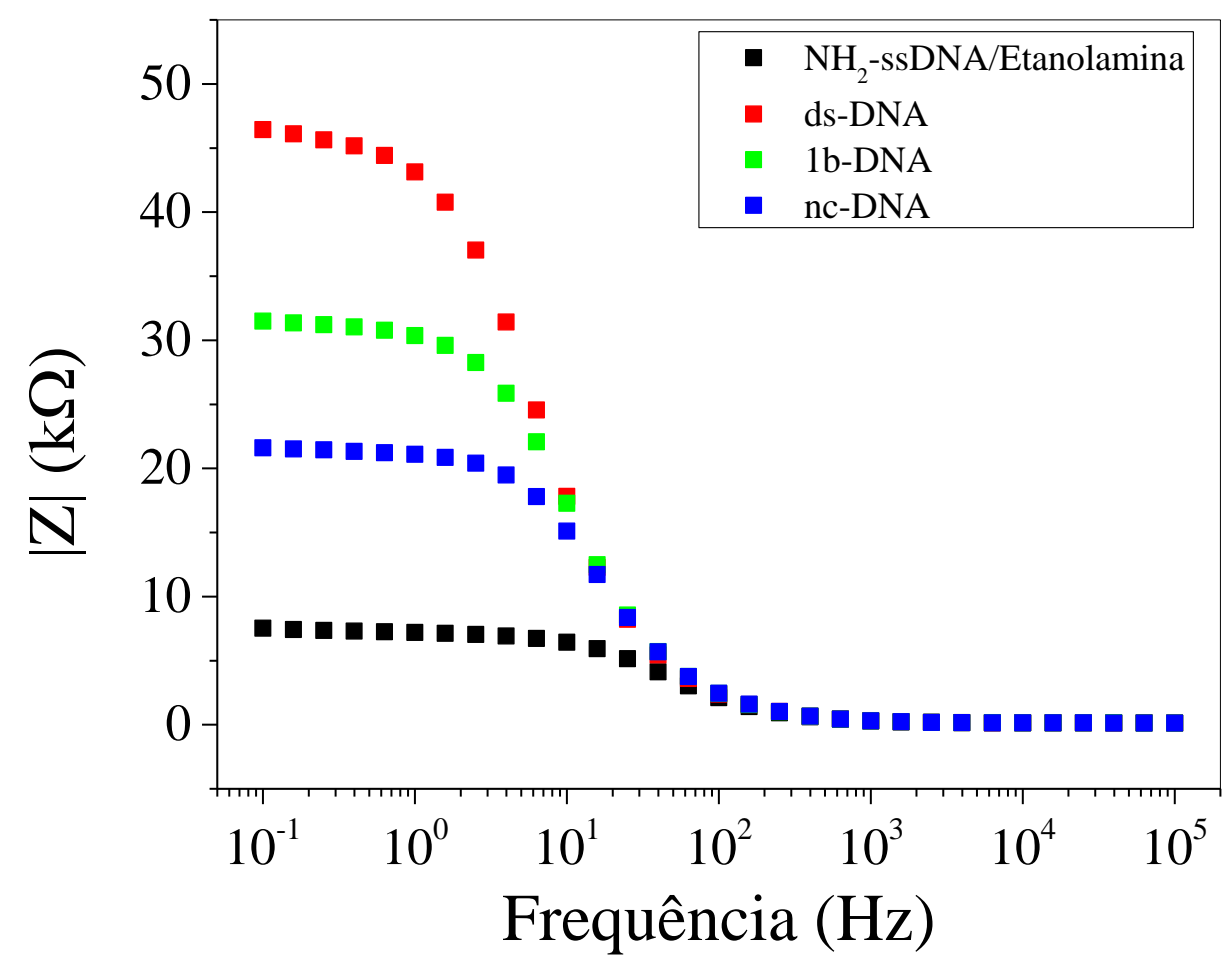

Fonte: Elaborado pela autora.

A Figura 40 apresenta a diferença do sinal de impedância das diferentes sequências em $1 \mathrm{~Hz}$. A sequência complementar (ds-DNA) gerou maior sinal do que as outras sequências, mostrando que houve hibridização das duas fitas. A sequência 1b-DNA tem a mesma sequência de bases da ds-DNA, porém uma base central é diferente. Isso significa que uma base não é complementar à sonda $\mathrm{NH}_{2}$-ssDNA, havendo assim uma hibridização parcial, e o sinal é então menor que aquele do dsDNA. 
Figura 40: Gráfico da diferença de sinal $\left(|Z|-\left|Z_{0}\right|\right)$ correspondente à hibridização com $1 \mu \mathrm{M}$ das diferentes sequências de DNA (ds-DNA, 1b-DNA, nc-DNA).

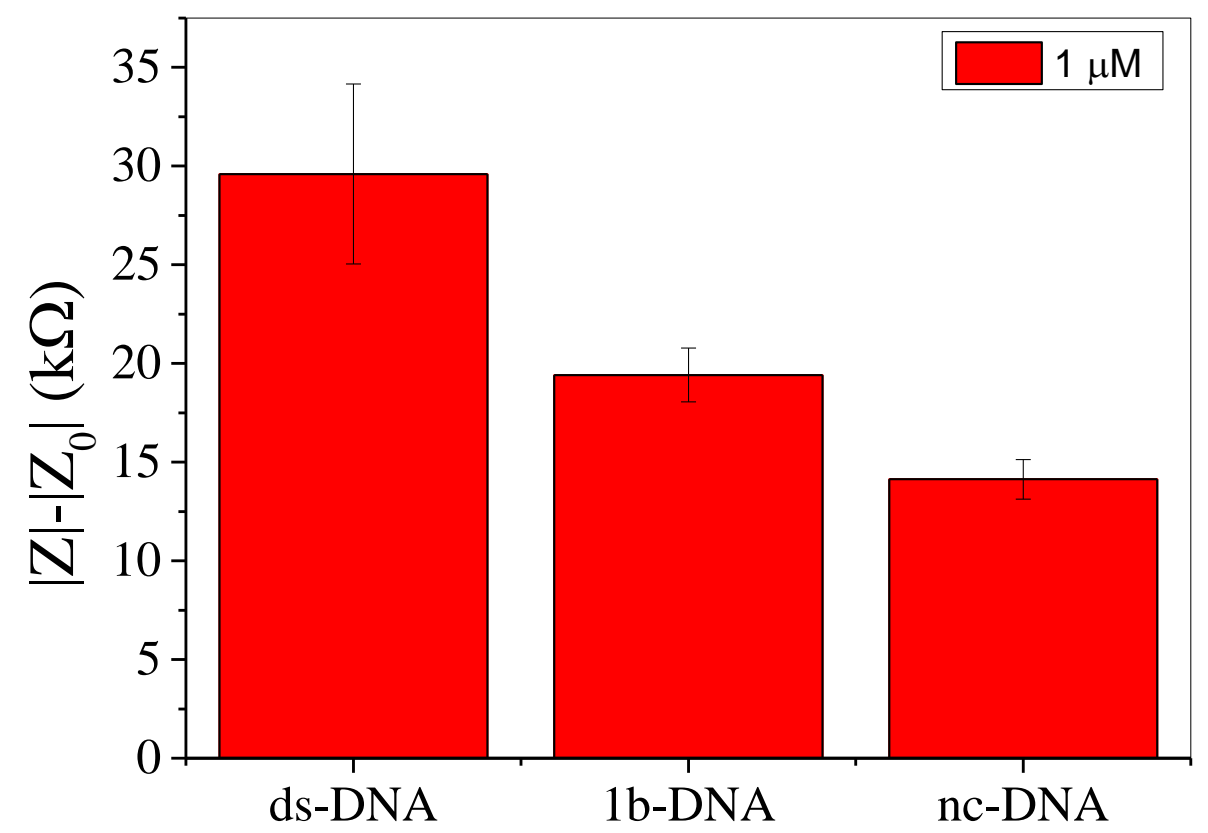

Fonte: Elaborado pela autora.

\subsection{Detecção em Amostras Reais}

Nas subseções anteriores foi estudada a detecção com amostras sintéticas a partir da plataforma com MUA, imobilizando a sonda e etanolamina como espaçador e bloqueador de sítios ativos. Como os resultados foram positivos, com distinção entre diferentes concentrações da sequência específica, pode-se agora verificar a possibilidade de detecção em amostras de células (que chamamos de "amostras reais"). Foram usadas as linhagens celulares HN13 (97\%), JHU28 (93\%), Fadu (3\%), SCC25 (2\%) com diferentes graus de metilação, em que o valor entre parênteses denota a porcentagem de metilação. Foi utilizada apenas uma concentração de 0,2 $\mathrm{ng} / \mu \mathrm{L}$ de DNA, pois existe uma limitação do volume das amostras fornecidas e a quantidade suficiente para cobrir a área ativa dos eletrodos. Essas amostras foram fornecidas pelo Hospital de Câncer de Barretos. A Figura 41 apresenta os espectros de impedância dos DNAs metilados hibridizados na sonda. A impedância aumentou 
com o grau de metilação, pois quanto maior a quantidade de citosina metilada a sequência se aproxima da sequência complementar (ds-DNA) discutida até agora. Isso acontece porque os DNAs metilados passam por um tratamento com bissulfito de sódio que converte as citosinas não metiladas em uracilas, mantendo as citosinas metiladas em citosina.

Figura 41: Espectro de impedância correspondente à hibridização com $0,2 \mathrm{ng} / \mu \mathrm{L}$ de DNA com diferentes graus de metilação das linhagens de células SCC25, FaDu, JHU28, HN13.

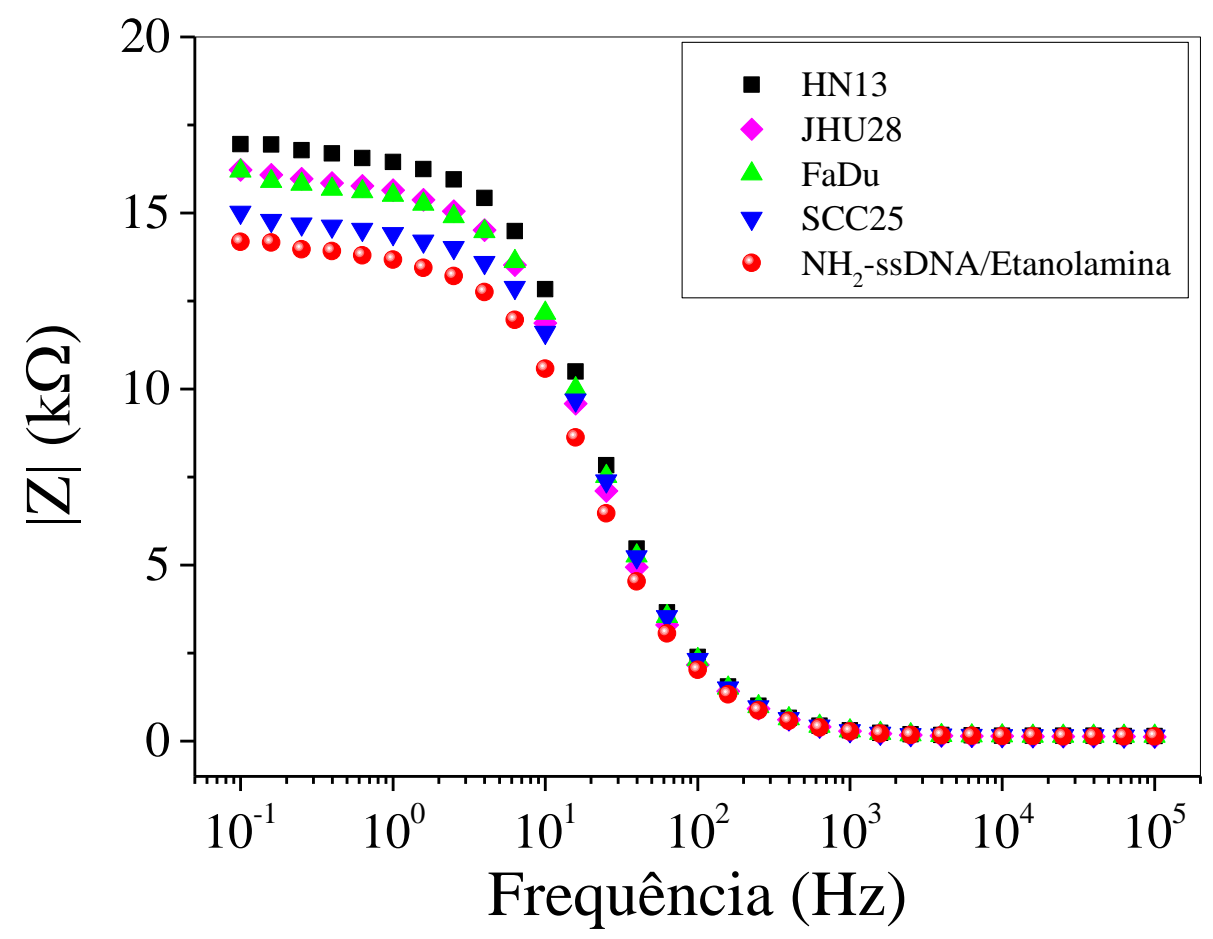

Fonte: Elaborado pela autora.

A Figura 42 apresenta a diferença do sinal de impedância dos DNAs metilados e a sonda $\left(\mathrm{NH}_{2}\right.$-ssDNA/Etanolamina) $\left(|\mathrm{Z}|-\left|\mathrm{Z}_{0}\right|\right)$ em $1 \mathrm{~Hz}$. A amostra com maior porcentagem de metilação (HN13) com $97 \%$ gerou o maior sinal, pois é a sequência complementar à sonda, ocorrendo hibridização. A amostra com menor porcentagem de metilação (SCC25), com 2\%, proporcionou o menor sinal, o que era esperado pois é a sequência não complementar à sonda; não ocorre hibridização nesse caso. As medidas foram feitas em triplicata para cada concentração de DNA e calculado o desvio padrão. 
Figura 42: Gráfico da diferença de sinal $\left(|Z|-\left|Z_{0}\right|\right)$ correspondente à hibridização com $0,2 \mathrm{ng} / \mu \mathrm{L}$ de DNA com diferentes graus de metilação das linhagens de células SCC25, FaDu, JHU28, HN13.

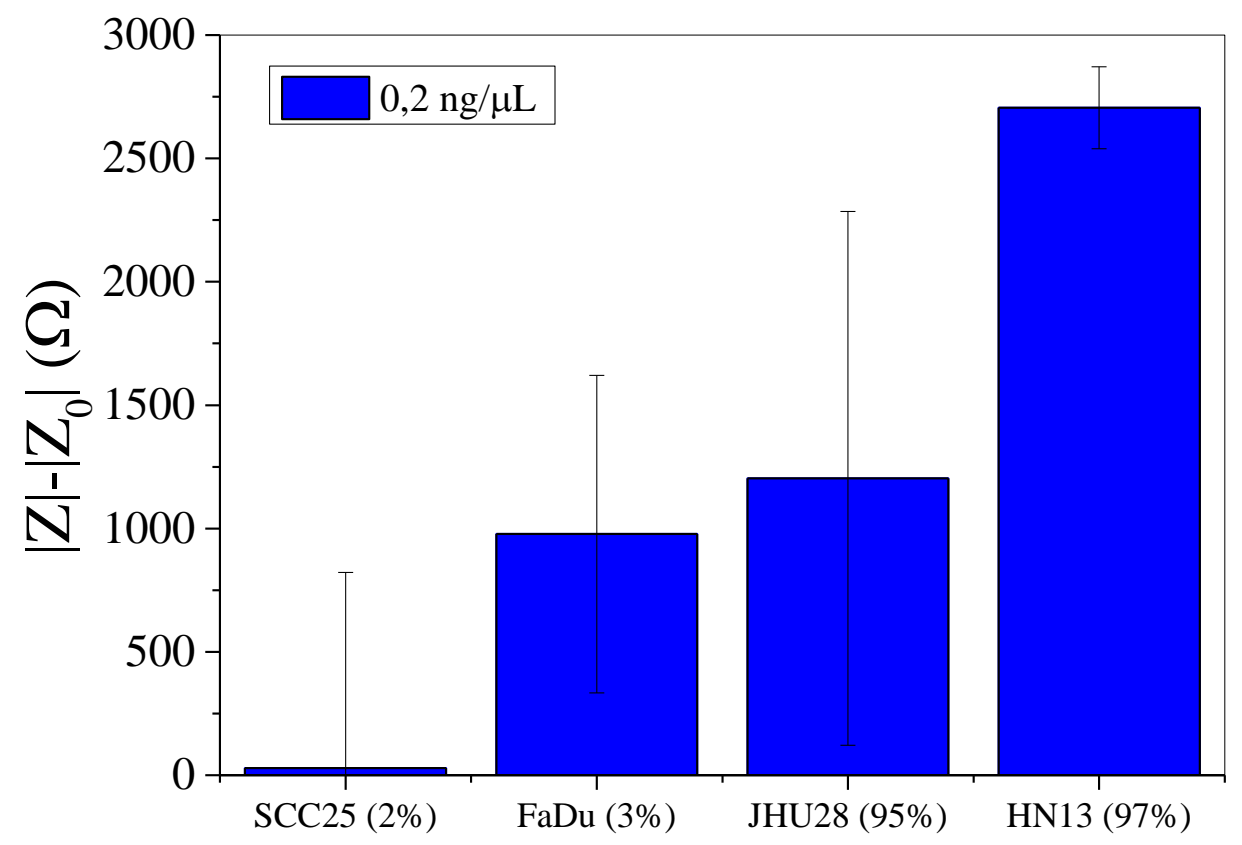

Fonte: Elaborado pela autora.

\subsubsection{Mapas de visualização dos dados}

O ótimo desempenho dos genossensores é comprovado na Figura 43, através da projeção das curvas de módulo da impedância versus frequência por IDMAP. Observa-se clara distinção entre as amostras com diferentes concentrações de DNA com a sequência complementar (ds-DNA) e não complementar (nc-DNA) (Figura 43a). As amostras de linhagens celulares com diferentes porcentagens de metilação da Figura 43b tiveram seus símbolos representativos separados, com amostras com alto grau de metilação (JHU28 e HN13) distantes das do sinal PBS. O coeficiente de silhueta para o mapa da Figura 43a é 0,359 , um valor relativamente baixo, pois a distinção completa levaria a um coeficiente igual a 1. Isso ocorre porque amostras com respostas eletroquímicas muito diferentes entre si foram colocadas no mapa, de maneira que as amostras da mesma classe (por exemplo, as amostras sintéticas com tampão PBS) ficaram próximas. Pode-se inferir, portanto, 
que a distinção deve ser mais eficiente se forem visualizados dados de amostras da mesma classe. De fato, para os dados das células apenas, o mapa da Figura 43b tem coeficiente de silhueta de 0,783 , confirmando a capacidade de distinção das amostras com o genossensor.

Figura 43: Mapas de IDMAP obtidos das curvas de impedância x frequência (a) de amostras comerciais (ds-DNA e nc-DNA)em PBS, (b) amostras de linhagens celulares graus de metilação das linhagens de células SCC25, FaDu, JHU28, HN13.

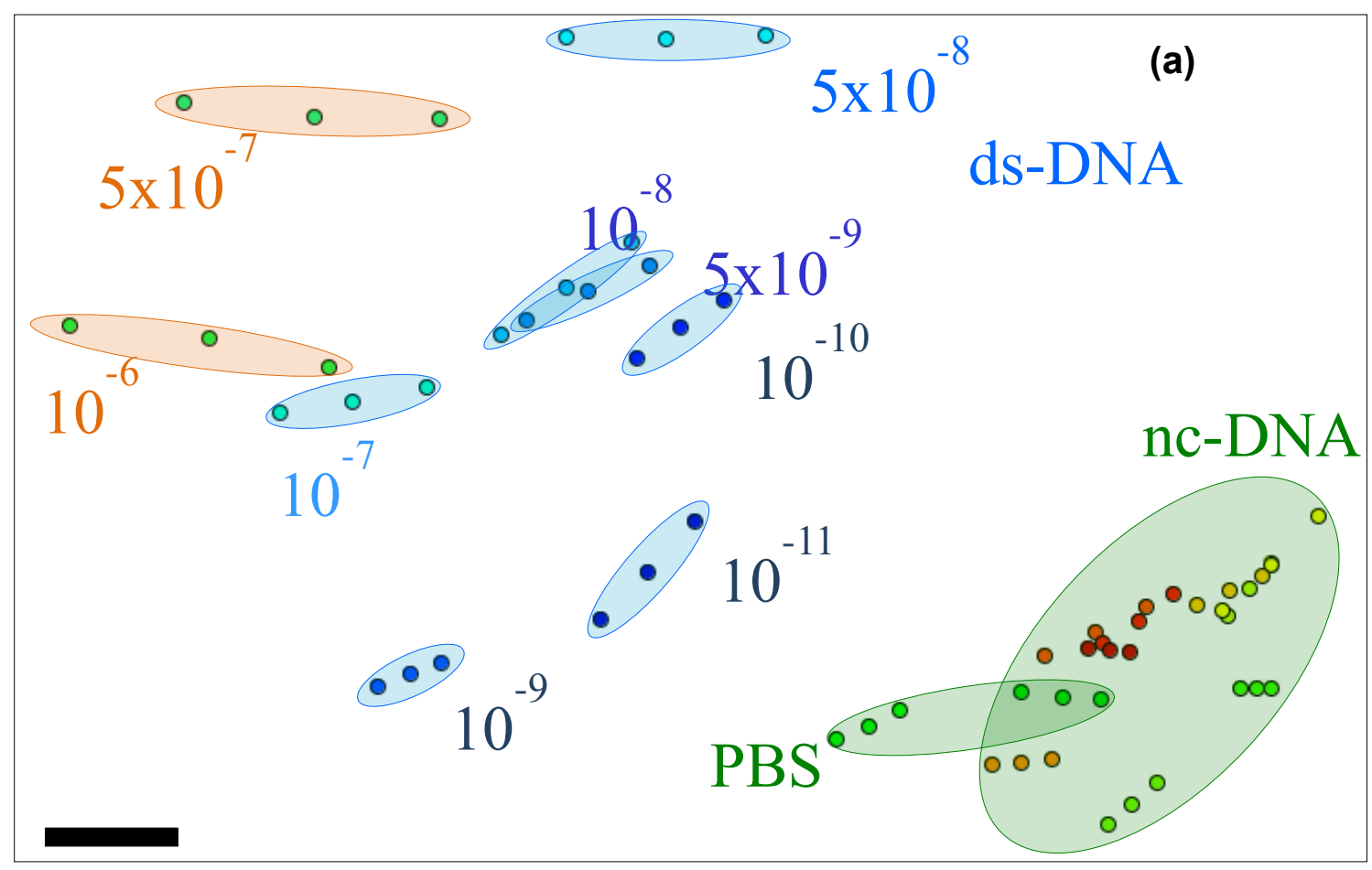

(Continua) 


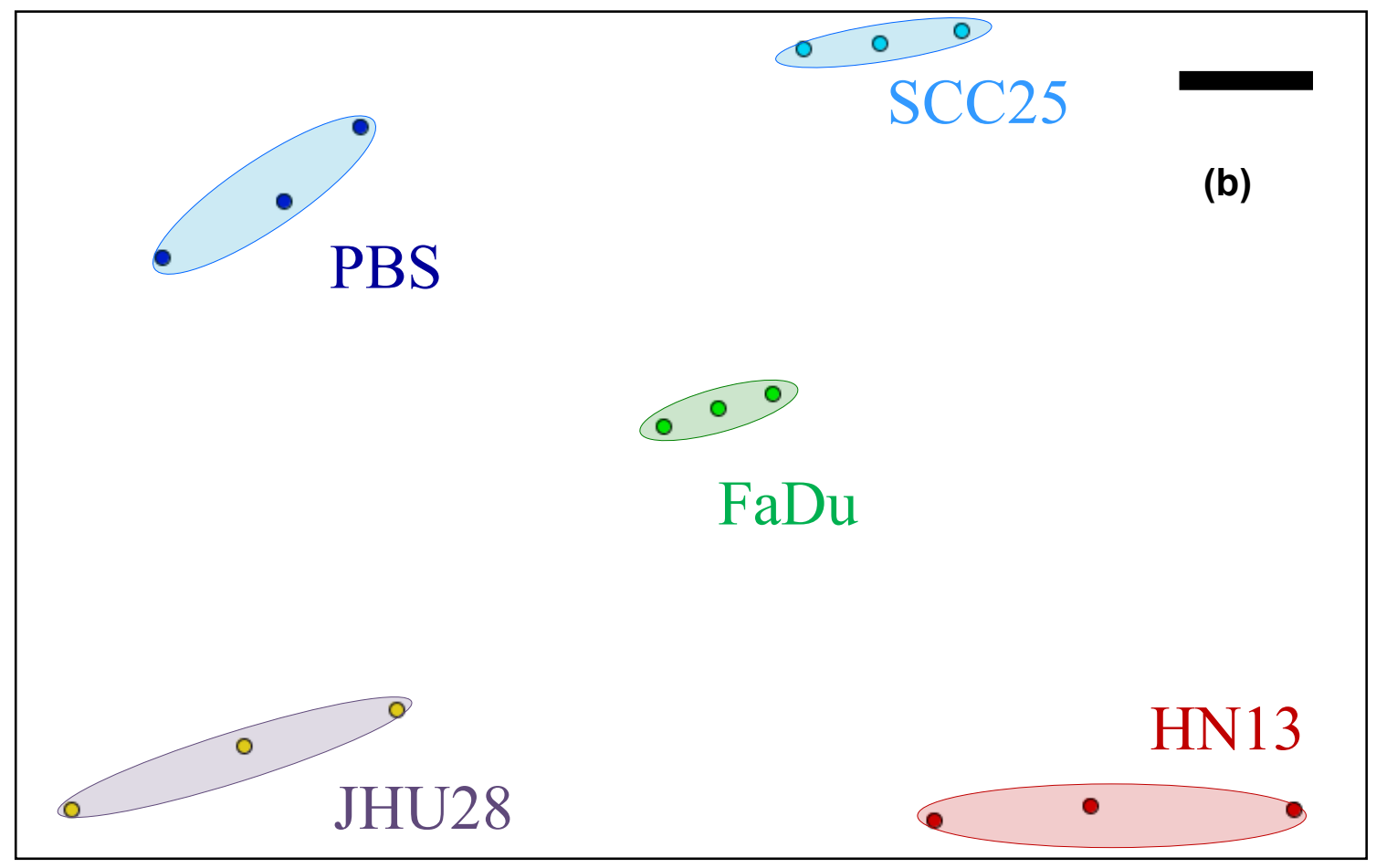

\subsubsection{Comparação com genossensores da literatura}

Genossensores têm sido usados para detecção de câncer pelas vantagens já mencionadas nesta tese, ou seja, há possibilidade de obter resultados de diagnóstico com técnicas mais simples que as empregadas atualmente (GALE, 2018). São vários os métodos de deteç̧ão usados nos trabalhos da literatura. Podem ser empregadas técnicas como espectroscopia de fluorescência (LOD de 1315 pM, HPV-16 e HPV-18) (WANG; PANG; TANG, 2014), medidas magnéticas (LOD de $10 \mathrm{nM}, \mathrm{HPV}$-18) (XU et al., 2008), e ópticas (LOD de 0,05 pmol/ $\mathrm{LL}$, HPV-6, HPV11, HPV-16, HPV-18) (LI et al., 2013). Dentre os eletroquímicos (JAISWAL et al., 2018), pode-se obter baixos limites de detecção, da ordem de $10^{-15} \mathrm{M}$ para sequência complementar de DNA de câncer de boca (CHEN et al., 2011). Essas plataformas medem o sinal de saída por voltametria cíclica (CV), voltametria de onda quadrada (SWV), voltametria de pulso diferencial (DPV) e espectroscopia de impedância eletroquímica (EIS) (HUANG et al., 2015) com limite de detecção de $4.03 \times 10^{-14} \mathrm{M}$. Um dos fatores que caracteriza esses genossensores com baixo limite de detecção é uso de materiais que amplificam o sinal, por exemplo $\left[\mathrm{Ru}(\text { phen })_{3}\right]^{(2+)}$ foi selecionado como indicador redox para amplificar o sinal eletroquímico (HUANG 
et al., 2015). Genossensores podem detectar outros tipos de cânceres, como o câncer de mama, com limite de detecção de 2,4 pM (EHZARI; SAFARI; SHAHLAEI, 2018). A metilação em DNA também vem sendo estudada para detecção de câncer, como na detecção do gene RASSF1A, supressor de tumor ligado a vários tipos de câncer, com o limite de detecção de 2 fM (DANESHPOUR et al., 2016). Para o câncer de próstata, na detecção do gene glutathione S-transferase P1 (GSTP1) obteve-se o limite de detecção de 2,92 pM (TOPKAYA et al., 2012).

Uma busca na literatura com os termos "genosensor and cancer" retorna quase 60 artigos, mas apenas 1 artigo se refere a genossensor para detecção de câncer de cabeça e pescoço utilizando amostras reais (SOARES et al., 2018). Trata-se de um genossensor para detectar o vírus do papiloma humano (HPV), em que o limite de detecção foi 10 pM. Amostras reais de DNA metilado têm sido um desafio para genossensores, devido a sua complexidade, o que deve explicar o pequeno número de trabalhos na literatura.

Apesar das dificuldades, há vantagens em usar DNA como biomarcador: rastreio de risco, utilizados para determinar a susceptibilidade da doença a um indivíduo, prognósticos que fornecem informações sobre a probabilidade da doença em um indivíduo não tratado; biomarcadores preditivos, proteínas ou genes específicos que indiquem sensibilidade ou resistência a uma terapia específica, e diagnóstico e monitoramento de doenças (DIXIT et al., 2016; LAOCHAROENSUK, 2016; RAMA; COSTA-GARCÍA, 2016). 


\section{CAPÍTULO 5- CONCLUSÕES E PERSPECTIVAS FUTURAS}

Neste trabalho foi proposta a construção de um genossensor para deteç̧ão precoce de câncer de cabeça e pescoço usando como analito sequências de DNA. Foram estudadas duas plataformas com monocamadas dos ácidos MUA e MAA na matriz do genossensor, caracterizadas empregando-se as técnicas de PM-IRRAS, SFG e medidas de ângulo de contato. As medidas de ângulo de contato mostraram a hidrolificidade das cadeias de DNA hibridizadas e não hibridizadas, confirmando a ligação entre a sonda e a sequência complementar. $O$ resultado da energia de superfície mostrou que a monocamada automontada (SAM) de ácido mercaptoacético (MAA) preparado em etanol aumenta a eficiência de imobilização da sonda $\left(\mathrm{NH}_{2}\right.$-SsDNA). Isso foi confirmado por PM-IRRAS, em que a SAM preparada em etanol teve maior exposição do grupo $\mathrm{COOH}$ na superfície. Nos espectros de PM-IRRAS e SFG, verificou-se que a monocamada automontada de MAA se organiza em um tempo de imobilização de 30 dias ou mais, o que não é viável para a construção de um genossensor. Esse resultado foi atribuído ao pequeno comprimento da cadeia do MAA (só dois carbonos), e a inadequação para matriz foi comprovada com as medidas de impedância eletroquímica, que é bastante sensível a mudanças na superfície do eletrodo. Dos resultados com MAA, conclui-se que para genossensores é essencial identificar a matriz adequada, preferivelmente com experimentos que permitam obter tal informação antes dos experimentos de sensoriamento que são muito custosos. Medidas por impedância eletroquímica mostraram que não foi possível obter um genossensor eficaz com a matriz de MAA, mesmo após várias tentativas. Experimentos com diferentes tempos e temperaturas de hibridização foram realizados e mostraram que não houve detecção das sequências complementares e não complementares. Ou seja, a arquitetura é relevante tanto na matriz como na camada ativa.

O emprego de algumas técnicas de caracterização das arquiteturas pode economizar muito trabalho. Neste projeto de doutorado, por exemplo, essa caracterização deveria ter sido buscada após os primeiros insucessos na obtenção de genossensores reprodutíveis e seletivos. Com a técnica de SFG, neste contexto, é possível obter informações detalhadas sobre arquiteturas moleculares. Nesta tese 
demonstrou-se que filmes automontados SAM precisam ser organizados para servirem de matriz. Esta foi a razão pela qual os genossensores produzidos com MAA não foram bem-sucedidos.

Utilizando-se uma monocamada de MUA na matriz, por outro lado, foi possível construir um genossensor eficiente, confirmando a importância da arquitetura molecular para um biossensor. Genossensores são especialmente dependentes da arquitetura molecular, pois a hibridização requer maior controle do que a interação antígeno-anticorpo de um imunossensor, por exemplo. Os espectros de impedância mostraram que a variação da impedância (|Z|-|Z $\mid)$ para a sequência complementar (ds-DNA) foi significativamente maior que para a sequência não complementar (nc-DNA). Isso indica que o genossensor é capaz de diferenciar uma amostra com resultado positivo ou negativo. Outro resultado relevante foi o do teste com interferentes, ou seja, com sequências que apresentavam algum defeito. Mostrou-se que o genossensor pode diferenciar as sequências, sendo que a complementar apresenta sinal maior do que as outras. Foram feitos testes com amostras reais de DNA com diferentes porcentagens de metilação na cadeia, observando-se maior sinal para a sequência HN13 que possui maior porcentagem de metilação (97\%), ou seja, a sequência que não possui bases trocadas devido ao tratamento com bissulfito de sódio.

Uma comprovação da detecção bem-sucedida do biomarcador de DNA, inclusive para amostras de células com diferentes graus de metilação no DNA, foi obtida com técnicas de visualização de informação. Gráficos de IDMAP mostraram que os dados de impedância eletroquímica podem ser distinguidos de acordo com a concentração do biomarcador, e tipo de célula. Dentre os resultados dessa análise, observou-se que os dados para células com DNA com alta taxa de metilação ficaram distantes do tampão PBS. Destaque-se, também, que o genossensor apresentou limite de detecção $\left(0,24\right.$ pM) em uma faixa de concentração linear entre 1,0 × $10^{-11}$ e $5,0 \times 10^{-8} \mathrm{M}$ e entre $1,0 \times 10^{-8}$ e $1,0 \times 10^{-6} \mathrm{M}(277 \mathrm{pM})$, uma sensibilidade competitiva com outros genossensores da literatura. Nos casos da literatura em que a sensibilidade era maior (e menor limite de detecção), o genossensor continha materiais para amplificar o sinal. Um exemplo foi o uso de rutênio, em que se obteve limite de detecção de fento molar (HUANG et al., 2015). Se por um lado acrescentar novos materiais pode melhorar o desempenho, a arquitetura molecular do 
genossensor é mais dispendiosa de obter.

Como proposta para trabalhos futuros, sugere-se que o genossensor desenvolvido nesta tese possa ser usado para detectar porcentagens intermediárias de metilação na cadeia de DNA, o que permitirá uma resposta mais precisa para prognósticos. Prevê-se, também, que o genossensor pode ser produzido em dispositivos miniaturizados para diminuir a quantidade do material usado na detecção, haja vista que a necessidade de material de pacientes é uma limitação considerável. Ainda podem ser feito estudos detalhados de diferentes arquiteturas moleculares, usando PM-IRRAS e SFG, que permitam conceber genossensores mais eficazes, otimizar experimentos de hibridização para aumentar o número de medidas, utilizar a arquitetura com MUA para outros biomarcadores de DNA e para outras doenças. 


\section{REFERÊNCIAS}

ALBERTS, B. et al. Molecular Biology of the Cell. 6. ed. New York/Abingdon: Garland Science: Taylor \& Francis Group, 2014.

ALEXANDROV, L. B. et al. Signatures of mutational processes in human cancer. Nature, v. 500, n. 7463, p. 415-421, 2013.

AOKI, K. Theory of phase separation of binary self-assembled films. Journal of Electroanalytical Chemistry, v. 513, n. 1, p. 1-7, out. 2001.

ARANTES, L. M. R. B. et al. Methylation as a biomarker for head and neck cancer. Oral Oncology, v. 50, n. 6, p. 587-592, jun. 2014.

BAIN, C. D. et al. Formation of monolayer films by the spontaneous assembly of organic thiols from solution onto gold. Journal of the American Chemical Society, v. 111, n. 1, p. 321-335, jan. 1989.

BAIN, C. D.; EVALL, J.; WHITESIDES, G. M. Formation of monolayers by the coadsorption of thiols on gold: variation in the head group, tail group, and solvent. Journal of the American Chemical Society, v. 111, n. 18, p. 7155-7164, ago. 1989. BORA, U. Nucleic Acid Based Biosensors for Clinical Applications. Biosensors Journal, v. 02, n. 01, 2013.

BREWER, S. H. et al. Detection of DNA Hybridization on Gold Surfaces by Polarization Modulation Infrared Reflection Absorption Spectroscopy. Langmuir, v. 18, n. 11, p. 4460-4464, maio 2002.

CASFORD, M. T. L. et al. The Structure of Lipid Bilayers Adsorbed on Activated Carboxy-Terminated Monolayers Investigated by Sum Frequency Generation Spectroscopy. The Journal of Physical Chemistry B, v. 118, n. 12, p. 3335-3345, 27 mar. 2014.

CHAMBERS, J. P. et al. Biosensor recognition elements. Current issues in molecular biology, v. 10, n. 1-2, p. 1-12, 2008.

CHEN, J. et al. An ultrasensitive electrochemical biosensor for detection of DNA species related to oral cancer based on nuclease-assisted target recycling and amplification of DNAzyme. Chemical Communications, v. 47, n. 28, p. 8004, 2011. 
CHINAGLIA, D. L. et al. Espectroscopia de impedância no laboratório de ensino. Revista Brasileira de Ensino de Física, v. 30, n. 4, p. 4504.1-4504.9, dez. 2008.

CHUNG, C.; LEE, M. Self-Assembled Monolayers of Mercaptoacetic Acid on Ag Powder: Characterization by FT-IR Diffuse Reflection Spectroscopy. Bulletin of the Korean Chemical Society, v. 25, n. 10, p. 1461-1462, 20 out. 2004.

DAMOS, F. S.; MENDES, R. K.; KUBOTA, L. T. Aplicações de QCM, EIS e SPR na investigação de superfícies e interfaces para o desenvolvimento de (bio)sensores. Química Nova, v. 27, n. 6, p. 970-979, dez. 2004.

DANESHPOUR, M. et al. Femtomolar level detection of RASSF1A tumor suppressor gene methylation by electrochemical nano-genosensor based on Fe $3 \mathrm{O} 4$ /TMC/Au nanocomposite and PT-modified electrode. Biosensors and Bioelectronics, v. 77, p. 1095-1103, mar. 2016.

DIAMOND, D. Principles of Chemical and Biological Sensors. 1. ed. [s.I.] WileyBlackwell, 1999.

DIXIT, C. K. et al. Electrochemistry-based approaches to low cost, high sensitivity, automated, multiplexed protein immunoassays for cancer diagnostics. The Analyst, v. 141 , n. 2 , p. $536-547,2016$.

DUTRA, R. C. L.; SOARES, B. G. Determination of the vinyl mercaptoacetate content in poly(ethylene-co-vinyl acetate-co-vinyl mercaptoacetate)(EVASH) by TGA analysis and FTIR spectroscopy. J-GLOBAL, v. 41, n. 1, p. 61-67, 1998.

E. FERAPONTOVA, E. Electrochemical Indicators for DNA Electroanalysis. Current Analytical Chemistry, v. 7, n. 1, p. 51-62, 1 jan. 2011.

E.OLIVEIRA, J. et al. Uso de polímeros condutores em sensores. Parte 3: Biossensores. Revista Eletrônica de Materiais e Processos, v. 8, p. 1-11, 2013.

EDSON GIULIANI RAMOS FERNANDES. Biossensores nanoestruturados para monitoração de glicose. [s.I.] Universidade Federal de Itajubá, 2005.

EHZARI, H.; SAFARI, M.; SHAHLAEI, M. A simple and label-free genosensor for BRCA1 related sequence based on electrospinned ribbon conductive nanofibers. Microchemical Journal, v. 143, p. 118-126, dez. 2018.

ESCOLA, B. DNA. Disponível em: <https://brasilescola.uol.com.br/biologia/dna.htm>. 
Acesso em: 18 dez. 2019.

FABRI-FAJA, N. et al. Early sepsis diagnosis via protein and miRNA biomarkers using a novel point-of-care photonic biosensor. Analytica Chimica Acta, v. 1077, p. 232-242, out. 2019.

FARJAMI, E. et al. DNA interactions with a Methylene Blue redox indicator depend on the DNA length and are sequence specific. The Analyst, v. 135, n. 6, p. 1443, 2010.

FENG, B. et al. Hydrophobic catalysis and a potential biological role of DNA unstacking induced by environment effects. Proceedings of the National Academy of Sciences, v. 116, n. 35, p. 17169-17174, 27 ago. 2019.

FERNANDO SÉRGIO ROFRIGUES RIBEIRO TELES. Desenvolvimento de um biossensor para a detecção e identificação do vírus da dengue em fluidos biológicos. [s.I.] Universidade Federal de Pernambuco, 2006.

FOWKES, F. M. ATTRACTIVE FORCES AT INTERFACES. Industrial \& Engineering Chemistry, v. 56, n. 12, p. 40-52, dez. 1964.

GALE, R. P. Diagnóstico de câncer. Disponível em: <https://www.msdmanuals.com/pt-br/profissional/hematologia-e-oncologia/visãogeral-sobre-câncer/diagnóstico-de-câncer>. Acesso em: 20 dez. 2019.

GRIESHABER, D. et al. Electrochemical Biosensors - Sensor Principles and Architectures. Sensors, v. 8, n. 3, p. 1400-1458, 7 mar. 2008.

GROBE, A. et al. Prognostic Relevance of Circulating Tumor Cells in Blood and Disseminated Tumor Cells in Bone Marrow of Patients with Squamous Cell Carcinoma of the Oral Cavity. Clinical Cancer Research, v. 20, n. 2, p. 425-433, 15 jan. 2014.

HINTERWIRTH, H. et al. Quantifying Thiol Ligand Density of Self-Assembled Monolayers on Gold Nanoparticles by Inductively Coupled Plasma-Mass Spectrometry. ACS Nano, v. 7, n. 2, p. 1129-1136, 26 fev. 2013.

HUANG, $H$. et al. An ultrasensitive electrochemical DNA biosensor based on graphene/Au nanorod/polythionine for human papillomavirus DNA detection. Biosensors and Bioelectronics, v. 68, p. 442-446, jun. 2015. 
HVASTKOVS, E. G.; BUTTRY, D. A. Recent advances in electrochemical DNA hybridization sensors. The Analyst, v. 135, n. 8, p. 1817, 2010.

INSELBERG, A.; DIMSDALE, B. Parallel coordinates: a tool for visualizing multidimensional geometry. Proceedings of the First IEEE Conference on Visualization: Visualization '90. Anais...IEEE Comput. Soc. Press, 1990Disponível em: $<$ http://ieeexplore.ieee.org/document/146402/>

JAISWAL, N. et al. Electrochemical genosensor based on carboxylated graphene for detection of water-borne pathogen. Sensors and Actuators B: Chemical, v. 275, p. 312-321, dez. 2018.

JIANG, J.; KUCERNAK, A. Nanostructured platinum as an electrocatalyst for the electrooxidation of formic acid. Journal of Electroanalytical Chemistry, v. 520, n. 1-2, p. 64-70, fev. 2002.

KALKREUTER, E. et al. Development of a Genetically Encoded Biosensor for Detection of Polyketide Synthase Extender Units in Escherichia coli. ACS Synthetic Biology, v. 8, n. 6, p. 1391-1400, 21 jun. 2019.

L., K.; T., K.; M., A. Head and neck cancer: Changing epidemiology and public health implications. ONCOLOGY, 2010.

LABUDA, J. et al. Electrochemical nucleic acid-based biosensors: Concepts, terms, and methodology (IUPAC Technical Report). Pure and Applied Chemistry, v. 82, n. 5, p. 1161-1187, 20 abr. 2010.

LAMBERT, A. G.; DAVIES, P. B.; NEIVANDT, D. J. Implementing the Theory of Sum Frequency Generation Vibrational Spectroscopy: A Tutorial Review. Applied Spectroscopy Reviews, v. 40, n. 2, p. 103-145, maio 2005.

LAOCHAROENSUK, R. Development of Electrochemical Immunosensors towards Point-of-care Cancer Diagnostics: Clinically Relevant Studies. Electroanalysis, v. 28, n. 8, p. 1716-1729, ago. 2016.

LEE, J.-O. et al. Aptamers as molecular recognition elements for electrical nanobiosensors. Analytical and Bioanalytical Chemistry, v. 390, n. 4, p. 1023 1032, 23 fev. 2008.

LEHNINGER, A. L.; NELSON, D. L.; COX, M. M. Princípios de Bioquímica. 4.ed. ed. São Paulo: SARVIER, 2006. 
LI, X. Z. et al. Optical detection of nanoparticle-enhanced human papillomavirus genotyping microarrays. Biomedical Optics Express, v. 4, n. 2, p. 187, 1 fev. 2013.

LUZ, A. P.; RIBEIRO, S.; PANDOLFELLI, V. C. Artigo revisão: Uso da molhabilidade na investigação do comportamento de corrosão de materiais refratários. Cerâmica, v. 54 , p. $174-183,2008$.

MAIA, F. C. B.; MIRANDA, P. B. Molecular Ordering of Conjugated Polymers at Metallic Interfaces Probed by SFG Vibrational Spectroscopy. The Journal of Physical Chemistry C, v. 119, n. 13, p. 7386-7399, 2 abr. 2015.

MATERIAIS, G. DE P. E. Ângulo de contato e energia de superfície. Disponível em: <https://www2.sorocaba.unesp.br/gpm/angulo cont energia superf.htm>. Acesso em: 6 dez. 2019.

MEHRVAR, M. et al. Fiber-optic biosensors: trends and advances. Analytical Sciences, v. 16, p. 677-692, 2000.

MEHRVAR, M.; ABDI, M. Recent Developments, Characteristics, and Potential Applications of Electrochemical Biosensors. Analytical Sciences, v. 20, n. 8, p. 1113-1126, 2004.

MELO, R. S.; MAIA, F. T. M. Avaliação do Uso de Circuitos Equivalentes na Análise por Impedância Eletroquímica de Revestimentos Anticorrosivos. Revista de Engenharias da Faculdade Salesiana, p. 2-9, 2015.

MENDELSOHN, R.; MAO, G.; FLACH, C. R. Infrared reflection-absorption spectroscopy: Principles and applications to lipid-protein interaction in Langmuir films. Biochimica et Biophysica Acta (BBA) - Biomembranes, v. 1798, n. 4, p. 788-800, abr. 2010.

MILLER, J. C.; MILLER, J. N. Basic statistical methods for analytical chemistry: Part I. Statistics of repeated measurements: A review. Analyst, v. 113, n. 9, p. 1351-1356, 1988.

MONOŠÍK, R.; STREĎANSKÝ, M.; ŠTURDÍK, E. Biosensors - classification, characterization and new trends. Acta Chimica Slovaca, v. 5, n. 1, p. 109-120, 1 abr. 2012.

MONTEBUGNOLI, L. et al. Clinicopathologic Parameters Related to Recurrence and Locoregional Metastasis in 180 Oral Squamous Cell Carcinomas. International 
Journal of Surgical Pathology, v. 22, n. 1, p. 55-62, 10 fev. 2014.

MORAES, M. L. et al. Detection of glucose and triglycerides using information visualization methods to process impedance spectroscopy data. Sensors and Actuators B: Chemical, v. 166-167, p. 231-238, maio 2012.

ORTIZ, M. et al. Elucidation of the mechanism of single-stranded DNA interaction with methylene blue: A spectroscopic approach. Journal of Photochemistry and Photobiology A: Chemistry, v. 218, n. 1, p. 26-32, fev. 2011.

OWENS, D. K.; WENDT, R. C. Estimation of the surface free energy of polymers. Journal of Applied Polymer Science, v. 13, n. 8, p. 1741-1747, ago. 1969.

PALEČEK, E.; BARTOŠíK, M. Electrochemistry of Nucleic Acids. Chemical Reviews, v. 112, n. 6, p. 3427-3481, 13 jun. 2012.

PAN, D. et al. Electrochemical Interrogation of Interactions between SurfaceConfined DNA and Methylene Blue. Sensors, v. 7, n. 11, p. 2671-2680, 12 nov. 2007.

PANIEL, N. et al. Aptasensor and genosensor methods for detection of microbes in real world samples. Methods, v. 64, n. 3, p. 229-240, dez. 2013.

PATHAK, P.; KATIYAR, V. K.; GIRI, S. Cancer Research - Nanoparticles, Nanobiosensors and Their Use in Cancer Research. AZojono Journal of Nanotechnology Online, v. 3, 2007.

PAULOVICH, F. V. et al. Information visualization techniques for sensing and biosensing. Analyst, v. 136, n. 7, p. 1344-1350, 7 abr. 2011.

PAVINATTO, A. et al. Experimental evidence for the mode of action based on electrostatic and hydrophobic forces to explain interaction between chitosans and phospholipid Langmuir monolayers. Colloids and Surfaces B: Biointerfaces, v. 145, p. 201-207, set. 2016.

PEDRERO, M.; CAMPUZANO, S.; PINGARRÓN, J. M. Electrochemical genosensors based on PCR strategies for microorganisms detection and quantification. Analytical Methods, v. 3, n. 4, p. 780, 2011.

RABOCKAI, T. Físico-Química de Superfícies. In: Físico-química de superfícies. Universidade da Califórnia: Secretaria-Geral da Organização dos Estados 
Americanos, Programa Regional de Desenvolvimento Científico e Tecnológico, 1979. p. 128.

RAITERI, R.; GRATTAROLA, M.; BERGER, R. Micromechanics senses biomolecules. Materials Today, v. 5, n. 1, p. 22-29, jan. 2002.

RAMA, E. C.; COSTA-GARCÍA, A. Screen-printed Electrochemical Immunosensors for the Detection of Cancer and Cardiovascular Biomarkers. Electroanalysis, v. 28, n. 8 , p. $1700-1715$, ago. 2016.

RIBEIRO, D. V.; SOUZA, C. A. C.; ABRANTES, J. C. C. Use of Electrochemical Impedance Spectroscopy (EIS) to monitoring the corrosion of reinforced concrete. Revista IBRACON de Estruturas e Materiais, v. 8, n. 4, p. 529-546, ago. 2015.

RIBEIRO TELES, F.; FRANÇA DOS PRAZERES, D.; DE LIMA-FILHO, J. Electrochemical Detection of a Dengue-related Oligonucleotide Sequence Using Ferrocenium as a Hybridization Indicator. Sensors, v. 7, n. 11, p. 2510-2518, 30 out. 2007.

RIGHINI, C. A. et al. Tumor-Specific Methylation in Saliva: A Promising Biomarker for Early Detection of Head and Neck Cancer Recurrence. Clinical Cancer Research, v. 13, n. 4 , p. $1179-1185,15$ fev. 2007.

SASSOLAS, A.; LECA-BOUVIER, B. D.; BLUM, L. J. DNA Biosensors and Microarrays. Chemical Reviews, v. 108, n. 1, p. 109-139, jan. 2008.

SELL, P.-J.; NEUMANN, A. W. The Surface Tension of Solids. Angewandte Chemie International Edition in English, v. 5, n. 3, p. 299-307, mar. 1966.

SHEN, Y. . Surfaces probed by nonlinear optics. Surface Science, v. 299-300, p. 551-562, jan. 1994.

SHEN, Y. R. Phase-Sensitive Sum-Frequency Spectroscopy. Annual Review of Physical Chemistry, v. 64, n. 1, p. 129-150, abr. 2013.

SLUYTERS-REHBACH, M.; SLUYTERS, J. H. On the impedance of galvanic cells XXVIII. The frequency-dependence of the electrode admittance for systems with firstorder homogeneous chemical reactions and reactant adsorption occurring simultaneously. Journal of Electroanalytical Chemistry and Interfacial Electrochemistry, v. 23, n. 3, p. 457-474, dez. 1969. 
SOARES, A. C. et al. Microfluidic-Based Genosensor To Detect Human Papillomavirus (HPV16) for Head and Neck Cancer. ACS Applied Materials \& Interfaces, v. 10, n. 43, p. 36757-36763, 31 out. 2018.

SONG, R.; LIU, Y.; HE, L. Synthesis and characterization of mercaptoacetic acidmodified ZnO nanoparticles. Solid State Sciences, v. 10, n. 11, p. 1563-1567, nov. 2008.

SOPER, S. A. et al. Point-of-care biosensor systems for cancer diagnostics/prognostics. Biosensors and Bioelectronics, v. 21, n. 10, p. $1932-$ 1942, abr. 2006.

STEEL, A. B.; HERNE, T. M.; TARLOV, M. J. Electrochemical Quantitation of DNA Immobilized on Gold. Analytical Chemistry, v. 70, n. 22, p. 4670-4677, nov. 1998.

STRADIOTTO, N. R.; YAMANAKA, H.; ZANONI, M. V. B. Electrochemical sensors: a powerful tool in analytical chemistry. Journal of the Brazilian Chemical Society, v. 14, n. 2, p. 159-173, abr. 2003.

SU, H.; LI, S.; KERMAN, K. Novel thiolated-PEG linker molecule for biosensor development on gold surfaces. Biosensors and Bioelectronics, v. 141, p. 111477 , set. 2019.

TELES, F.; FONSECA, L. Trends in DNA biosensors. Talanta, v. 77, n. 2, p. 606623, 15 dez. 2008.

THERMOFISHER. PCR Cycling Parameters-Six Key Considerations for Success. Disponivel em: <https://www.thermofisher.com/br/en/home/lifescience/cloning/cloning-learning-center/invitrogen-school-of-molecular-biology/pcreducation/pcr-reagents-enzymes/pcr-cycling-considerations.html>. Acesso em: 4 dez. 2019.

TOLSTOY, V. P.; CHERNYSHOVA, I. V.; SKRYSHEVSKY, V. A. HANDBOOK OF INFRARED SPECTROSCOPY OF ULTRATHIN FILMS. New Jersey: John Wiley \& Sons, 2003.

TOPKAYA, S. N. et al. Electrochemical DNA biosensor for detecting cancer biomarker related to glutathione S-transferase P1 (GSTP1) hypermethylation in real samples. Biosensors and Bioelectronics, v. 31, n. 1, p. 516-522, jan. 2012.

TOSAR, J. P.; BRAÑAS, G.; LAÍZ, J. Electrochemical DNA hybridization sensors 
applied to real and complex biological samples. Biosensors and Bioelectronics, v. 26, n. 4, p. 1205-1217, dez. 2010.

UEHARA, T. M. et al. Adsorption of Alkylthiol Self-Assembled Monolayers on Gold and the Effect of Substrate Roughness: A Comparative Study Using Scanning Tunneling Microscopy, Cyclic Voltammetry, Second-Harmonic Generation, and SumFrequency Generation. The Journal of Physical Chemistry C, v. 118, n. 35, p. 20374-20382, 4 set. 2014.

WANG, J. SURVEY AND SUMMARY: From DNA biosensors to gene chips. Nucleic Acids Research, v. 28, n. 16, p. 3011-3016, 15 ago. 2000.

WANG, J. Electrochemical nucleic acid biosensors. Analytica Chimica Acta, v. 469, n. 1, p. 63-71, set. 2002.

WANG, Q. et al. Investigation and identification of potential biomarkers in human saliva for the early diagnosis of oral squamous cell carcinoma. Clinica Chimica Acta, v. 427, p. 79-85, jan. 2014.

WANG, W.; PANG, D.-W.; TANG, H.-W. Sensitive multiplexed DNA detection using silica nanoparticles as the target capturing platform. Talanta, v. 128, p. 263-267, out. 2014.

WANG, W.; WANG, C.; LU, X. Electrochemical investigation on the film of L-cysteine self-assembled to nanoparticles on a gold electrode. Journal of Biophysical Chemistry, v. 03, n. 01, p. 39-43, 2012.

WANG, Y. et al. Electrochemical Sensors for Clinic Analysis. Sensors, v. 8, n. 4, p. 2043-2081, 27 mar. 2008.

WANG, Y.; SAURIAT-DORIZON, H.; KORRI-YOUSSOUFI, H. Direct electrochemical DNA biosensor based on reduced graphene oxide and metalloporphyrin nanocomposite. Sensors and Actuators B: Chemical, v. 251, p. 40-48, nov. 2017.

$\mathrm{XU}$, L. et al. Giant magnetoresistive biochip for DNA detection and HPV genotyping. Biosensors and Bioelectronics, v. 24, n. 1, p. 99-103, set. 2008.

YANG, W.; JUSTIN GOODING, J.; BRYNN HIBBERT, D. Characterisation of gold electrodes modified with self-assembled monolayers of I-cysteine for the adsorptive stripping analysis of copper. Journal of Electroanalytical Chemistry, v. 516, n. 1-2, p. 10-16, dez. 2001. 
YANTASEE, W. et al. Electrochemical Sensors for the Detection of Lead and Other Toxic Heavy Metals: The Next Generation of Personal Exposure Biomonitors. Environmental Health Perspectives, v. 115, n. 12, p. 1683-1690, dez. 2007.

ZHANG, C. Sum Frequency Generation Vibrational Spectroscopy for Characterization of Buried Polymer Interfaces. Applied Spectroscopy, v. 71, n. 8, p. 1717-1749, 6 ago. 2017.

ZHANG, G.-J. et al. DNA Sensing by Silicon Nanowire: Charge Layer Distance Dependence. Nano Letters, v. 8, n. 4, p. 1066-1070, abr. 2008.

ZHUANG, X. et al. Mapping molecular orientation and conformation at interfaces by surface nonlinear optics. Physical Review B, v. 59, n. 19, p. 12632-12640, 15 maio 1999. 